QA: QA

TDR-NBS-HS-000005 REV 00

MOL. 20020807.0442

July 2002

\title{
Data Qualification Report: Mineralogy Data for Use on the Yucca Mountain Project
}

By

T.L. Steinborn

Prepared for:

U.S. Department of Energy

Yucca Mountain Site Characterization Office P.O. Box 364629

North Las Vegas, Nevada 89036-8629

Prepared by:

Bechtel SAIC Company, LLC

1180 Town Center Drive

Las Vegas, Nevada 89144

Under Contract Number

DE-AC08-01RW12101 


\section{DISCLAIMER}

This report was prepared as an account of work sponsored by an agency of the United States Government. Neither the United States Government nor any agency thereof, nor any of their employees, nor any of their contractors, subcontractors or their employees, makes any warranty, express or implied, or assumes any legal liability or responsibility for the accuracy, completeness, or any third party's use or the results of such use of any information, apparatus, product, or process disclosed, or represents that its use would not infringe privately owned rights. Reference herein to any specific commercial product, process, or service by trade name, trademark, manufacturer, or otherwise, does not necessarily constitute or imply its endorsement, recommendation, or favoring by the United States Government or any agency thereof or its contractors or subcontractors. The views and opinions of authors expressed herein do not necessarily state or reflect those of the United States Government or any agency thereof. 
Data Qualification Report: Mineralogy Data for Use on the Yucca Mountain Project

Prepared by:

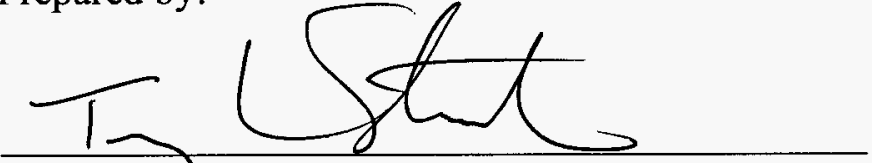

T.L. Steinlorn

Chairperson

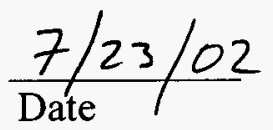

Compliance Review by:

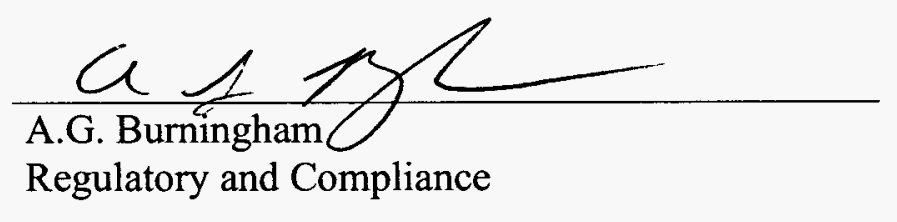

$\frac{7 / 3 / 102}{\text { Date }}$

Approved by:
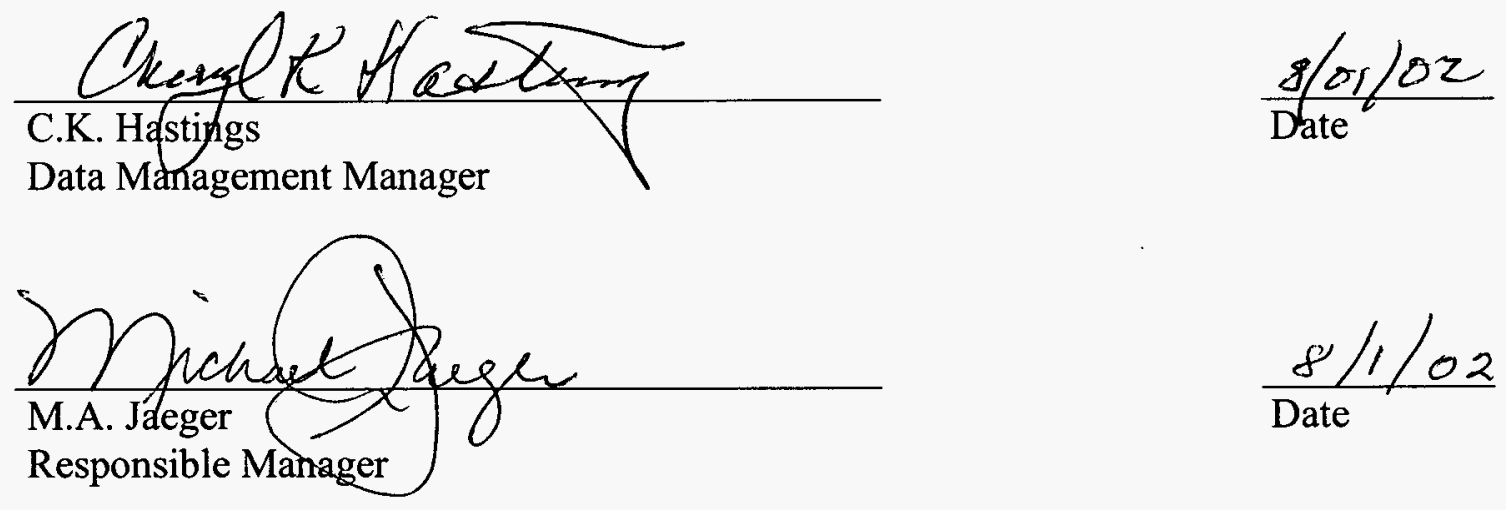


\section{EXECUTIVE SUMMARY}

This data qualification report (DQR) uses technical assessment methods according to Attachment 2 of AP-SIII.2Q, Rev. 0, ICN 4, Qualification of Unqualified Data and the Documentation of Rationale for Accepted Data, to qualify X-ray diffraction mineral analysis data. This DQR primarily considers Data Tracking Number (DTN) LADB831321AN98.002, Revised Mineralogic Summary of Yucca Mountain, Nevada, which is a source to the Mineralogical Model (MM3.0) (CRWMS M\&O 2000b). A qualification action was required for this data set because it was acquired prior to the acceptance of the Office of Civilian Waste Management (OCRWM) Quality Assurance Program in 1989. Three separate actions were required to determine that the mineral analysis data are qualified for use on the Yucca Mountain Project (YMP). These actions were: (1) qualification of the source material (drill core) used in DQR: Drill Core, Core Samples, Core Photos and Geophysical Logs for Boreholes, UE-25 a\#l, UE-25 a\#5, UE-25 a\#6, UE-25a\#7, UE-25 b\#1, USG G-1, USG G-2, USG G-3, USG G-4, USW $G U-3$ (CRWMS M\&O 2000a; TDR-NBS-GS-000006) and this DQR, (2) qualification of the process of collecting samples from the core, sample handling and control processes, and the actual X-ray diffraction analysis (this DQR), and (3) baselining of software POWD Version 10 (POWD10) (Pennsylvania State University 1983) used to analyze some of the X-ray diffraction results. Because the qualification of the source material only resulted in the qualification of the core from continuously-cored boreholes, this DQR has subdivided X-ray diffraction data in DTN LADB831321AN98.002 into 5 new DTNs based on the qualification results and type of source material. These are:

- MO0101XRDMINAB.001-This DTN is recommended for qualification. The X-ray diffraction data represent mineral abundance percentages obtained for 5 continuously-cored boreholes (UE-25b\#1, USW G-1, USW G-3, USW GU-3, and USW G-4) for which the core collection and storage process has been qualified.

- MO0101XRDDRILC.000-This DTN is not recommended for qualification. Core from the intermittently cored J-13 borehole were not qualified by this DQR.

- MO0106XRDDRILC.003-This DTN is recommended for qualification. The X-ray diffraction data represent mineral abundance percentages obtained from an intermittently cored borehole (USW H-6). The core from this borehole was not qualified by a separate qualification, but was determined to be representative of the depths indicated in this DQR.

- MO0101XRDDRILC.001-This DTN is not recommended for qualification. The X-ray diffraction data represent mineral abundance percentages from cuttings collected from 7 boreholes (UE $25 \mathrm{~J}-12$, UE-25p\#1, USW H-3, USW H-4, USW H-5, USW WT-1, and USW WT-2). These data were not qualified because of the difficulty in determining the location in the borehole from which cuttings samples were derived.

- MO0101XRDDRILC.002-This DTN is recommended for qualification. The X-ray diffraction data represent mineral abundance percentages obtained from 2 continuously cored boreholes (UE-25a\#1 and USW G-2). These data were largely derived using a 
different methodology (external standards vs. internal standards). This alternate method was found acceptable by this DQR.

Because this DQR only qualifies part of the data originally contained in DTN LADB831321AN98.002, users of this DTN (e.g., LA9910DB831321.001 and LA9908JC831321.001 [developed output from CRWMS M\&O 2000b]) will need to assess the impact of this qualification action and possibly revise their analyses or models when substituting the DTNs qualified by this DQR. 


\section{CONTENTS}

ACRONYMS AND ABBREVIATIONS xiii

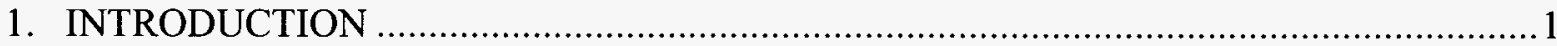

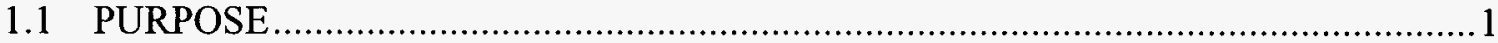

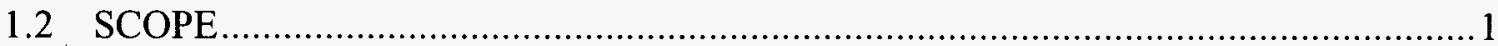

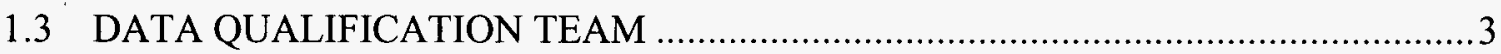

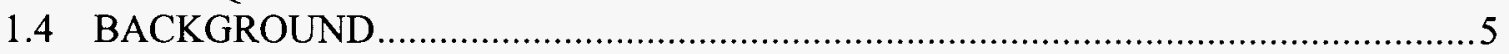

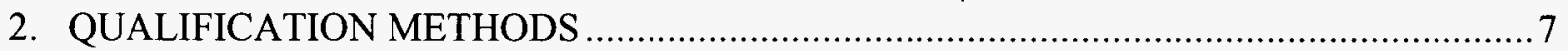

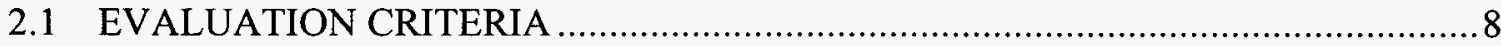

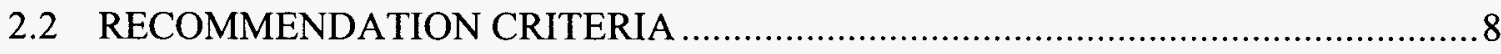

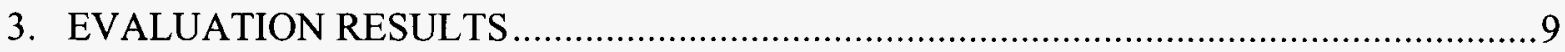

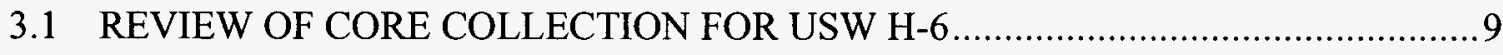

3.2 REVIEW OF CORE SAMPLING AND SAMPLE PREPARATION FOR XRD

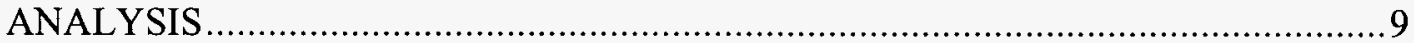

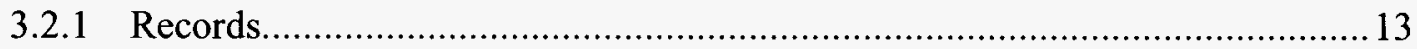

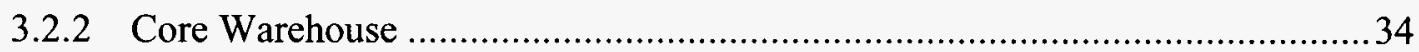

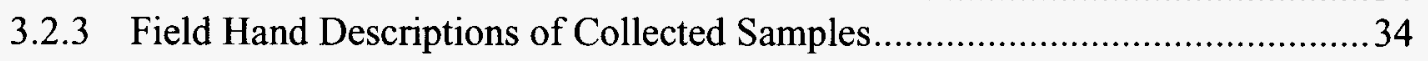

3.2.4 Sample Receipt, Crushing, and Forwarding to the XRD Lab ..........................36

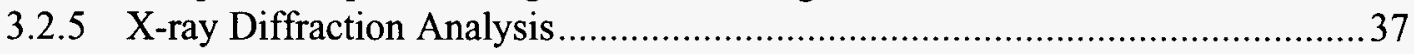

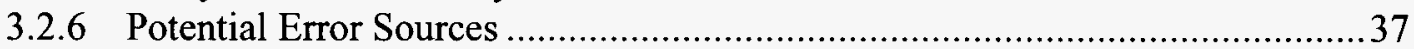

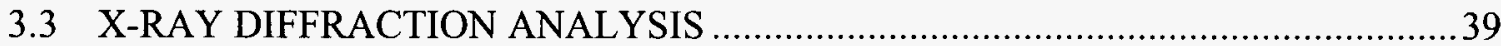

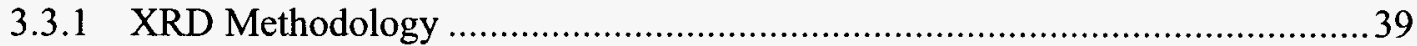

3.3.2 Software Program for XRD Synthetic Data ....................................... 41

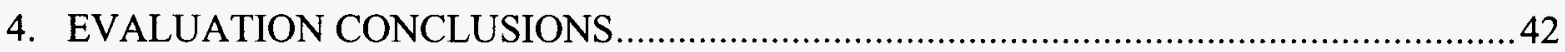

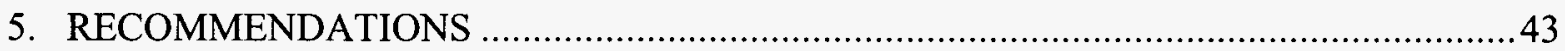

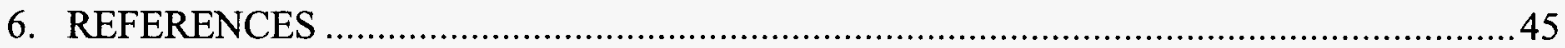

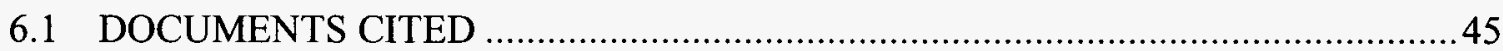

6.2 CODES, STANDARDS, REGULATIONS, AND PROCEDURES …......................48

6.3 SOURCE DATA, LISTED BY DATA TRACKING NUMBER ...............................49

6.4 OUTPUT DATA, LISTED BY DATA TRACKING NUMBER ...............................49

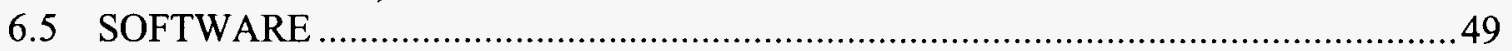


INTENTIONALLY LEFT BLANK 


\section{FIGURES}

Page

1. Relationship between XRD Source Data and Developed/Technical Product

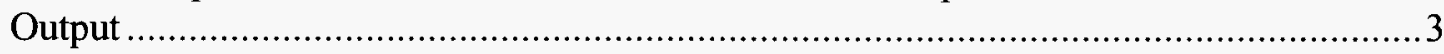


INTENTIONALLY LEFT BLANK 


\section{TABLES}

Page

1. DTNs Addressed in this Data Qualification Report. 2

2. Sample Extraction of a Small Part of the Data Set for Well USW G-4 in SEP Table G-4s98163_010 in DTN LADB831321AN98.002. Illustrating the Data Type and Structure 6

3. List of Boreholes in DTN LADB831321AN98.002, Material Type Analyzed, and Qualification Status of the Material....

4a. Boreholes with Previously Qualified Core from which Samples Were Collected

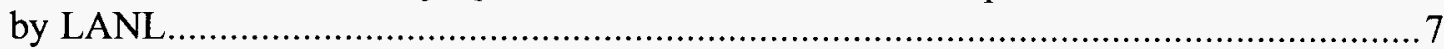

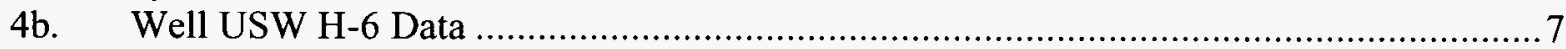

5. Investigators Involved in the Actual Sample Description and Collection........................12

6a. Detail Mapping of Samples from Collection to Analysis for UE-25b\#1 ...................... 14

6b. Detailed Mapping of Samples from Collection to Analysis for USW G-1 ................. 17

6c. Detail Mapping of Samples from Collection to Analysis for USW GU-3 3...................23

6d. Detail Mapping of Samples from Collection to Analysis for USW G-3......................27

6e. Detailed Mapping of Samples from Collection to Analysis for USW G-4 .................. 30

7. Notations of Sample Receipts and Transfers in Scientific Notebooks............................37

8. Summary of Qualification Issues for Core Samples in DTN LADB831321 AN98.002 …............................................................................ 40

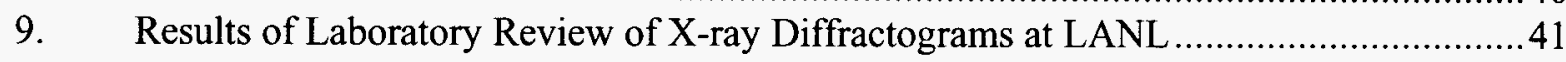

10. List of DTNs Created or Affected by this Data Qualification Report ..........................44 


\section{INTENTIONALLY LEFT BLANK}




\section{ACRONYMS AND ABBREVIATIONS}

\begin{tabular}{|c|c|}
\hline AMR & analysis/model report \\
\hline DTN & data tracking number \\
\hline DQP & data qualification plan \\
\hline DQR & data qualification report \\
\hline LANL & Los Alamos National Laboratory \\
\hline POWD 10 & POWD Version 10 software program \\
\hline QA & Quality Assurance \\
\hline QAPP & Quality Assurance Program Plan (LANL) \\
\hline QARD & Quality Assurance Requirements and Description \\
\hline SMF & Sample Management Facility \\
\hline TBV & to be verified \\
\hline TPO & technical product output \\
\hline USGS & U.S. Geological Survey \\
\hline WMPO & Waste Management Project Office \\
\hline XRD & $\mathrm{X}$-ray diffraction \\
\hline YMP & Yucca Mountain Project \\
\hline
\end{tabular}


INTENTIONALLY LEFT BLANK 


\section{INTRODUCTION}

\subsection{PURPOSE}

This DQR uses the technical assessment methods according to Attachment 2 of AP-SIII.2Q, Rev. 0, ICN 3, to qualify DTN LADB831321AN98.002. The data addressed in this DQR have been cited in CRWMS M\&O (2000b) to support the Site Recommendation in determining the suitability of Yucca Mountain as a repository for high level nuclear waste. CRWMS M\&O (2000b) refers to mineral analyses that are unqualified. Within the context of this DQR, the term mineral analyses includes: (1) the determination of the identity of specific crystalline phases from the Yucca Mountain Site by X-ray diffraction (XRD) analysis, as well as, (2) determination of mineral abundance as a percentage of the total mineral content of samples collected from drill core, side wall core and drill cuttings. These data are used among other purposes to define the spatial distribution of minerals at the Yucca Mountain Site, for correlation with geologic properties, and may be used as input in developing both unsaturated and saturated zone flow and transport models for the YMP Total System Performance Assessment. This DQR evaluates the unqualified data within DTNs within the context of supporting such kinds of studies on the YMP. The unqualified data considered in this DQR were identified and directly used in CRWMS M\&O (2000b) in which the mineral analyses are used to create three-dimensional representations of mineral distributions.

The purpose of this DQR is to recommend data that can be cited as qualified for use in technical products to support the License Application. The qualified data were placed in new DTNs generated as a result of the evaluation. The appropriateness and limitations (if any) of the data with respect to intended use are addressed in this DQR.

In accordance with Attachment 1 of procedure AP-3.15Q, Rev. 3, ICN 2, Managing Technical Product Inputs, it has been determined that the unqualified mineral abundance data for core material are not used in the direct calculation of Principal Factors for post closure safety or disruptive events.

\subsection{SCOPE}

This DQR evaluates the data identified in Data Qualification Plan for X-Ray Diffraction Mineral Abundance Data for Use on the Yucca Mountain Project (Bassett et al. 2001). The data qualification plan (DQP) identifies four unqualified DTNs containing or using acquired and developed mineral abundance data measured by investigators at Los Alamos National Laboratory (LANL) and cited in LANL reports (Bish and Chipera 1986, 1989; Chipera et al. 1995). A subset of the mineral abundance data in these DTNs is used directly in mapping the distribution of a selected number of minerals and also used directly in correlation with hydraulic properties for specific lithostratigraphic intervals.

These data are generally unqualified because they were acquired in the 1981 to 1986 time frame, prior to the OCRWM Quality Assurance Requirements and Description (QARD), and procedures that had not, at that time, been approved for YMP work. YMP approval was obtained for LANL in 1991 (Horton 1990). Specifically, the Data Qualification Team identified the following actions that it felt were required to arrive at a determination that the data are qualified for use: 
(1) a review of the traceability of samples from collection to analysis, (2) a review of methods used for the XRD analyses, and (3) the baselining into retirement of software program POWD10 (Pennsylvania State University 1983) used to identify two minerals: tridymite and stellerite. The last action is outside the scope of this DQR and was accomplished in accordance with the requirements of procedure AP-SI.1Q, Rev 2, ICN 4, ECN 1, Software Management.

Drill core, sidewall core, and drill cuttings, from wells at Yucca Mountain were analyzed for mineral abundance by XRD methods at LANL, and the results were included in DTNs LADV831321AQ97.001 and LADB831321AN89.002 examined here. Drill cuttings and sidewall cores are not generally considered representative of a specific geologic horizon to the same level of confidence as drill core. Consequently, only the XRD mineral analyses obtained from drill core material are the subject of this $\mathrm{DQR}$, and these drill core data have been placed in new DTNs, Table 10, p. 44. The analyses from cuttings and sidewall core have been placed in a separate DTN. Although the XRD methods for mineral analyses of drill cuttings and sidewall core could be qualified, these analyses were not recommended for qualification because of the uncertainty in identifying the stratigraphic location from which the samples were obtained. It is recommended that the sidewall core and drill cuttings data be used only to corroborate assumptions or other data in both the AMRs cited above.

The DTNs listed in Bassett et al. (2001) and in this DQR are given in Table 1.

Table 1. DTNs Addressed in this Data Qualification Report

\begin{tabular}{|l|l|}
\hline \multicolumn{1}{|c|}{ DTN } & \multicolumn{1}{c|}{ DTN CONTENT } \\
\hline LADV831321AQ97.001 & Mineralogic Variation in Drill Holes \\
\hline LA9908JC831321.001 & Mineralogic Model "MM3.0" Version 3.0 \\
\hline LA9910DB831321.001 & Mineralogic Variation in Drill Holes \\
\hline LADB831321AN98.002 & Revised Mineralogic Summary of Yucca Mountain, Nevada \\
\hline
\end{tabular}

The first DTN listed in Table 1 (LADV831321AQ97.001) is referenced in CRWMS M\&O $(2000 \mathrm{~b})$ and is identified in Bassett et al. (2001). Although this DTN is classified as Qualified To be Verified (Q-TBV), it was discovered simultaneously with the procedure AP-3.15Q verification assessment that software program POWD10 (Pennsylvania State University 1983) was used in selected XRD analyses. The software program would need to be baselined and retired to verify this DTN in accordance with procedure AP-3.15Q. Because the software was used in several DTNs that were generated both before and after the approval of the OCRWM QA program, it was decided to baseline and retire this program as a separate action to address all issues relating to its use. A member of this Data Qualification Team participated in the qualification of the POWD10 (Pennsylvania State University 1983) software.

Regarding the second and third DTNs in Table 1, LA9908JC831321.001 has 10 source DTNs and LA9910DB831321.001 has 7 source DTNs, and in both cases, all sources are qualified except for DTN LADB831321AN98.002 which is referenced in both. DTN LADB831321AN98.002 is the fourth DTN listed in Table 1. By qualifying data from DTN LADB831321AN98.002, all source DTNs for the previous two listed DTNs would be qualified and all qualified data can be referenced directly. Note the relationship between these DTNs as 
depicted in Figure 1. Note also the model output is considered Technical Product Output (TPO) and will not require qualification here; the source DTNs will be qualified and may be used elsewhere.

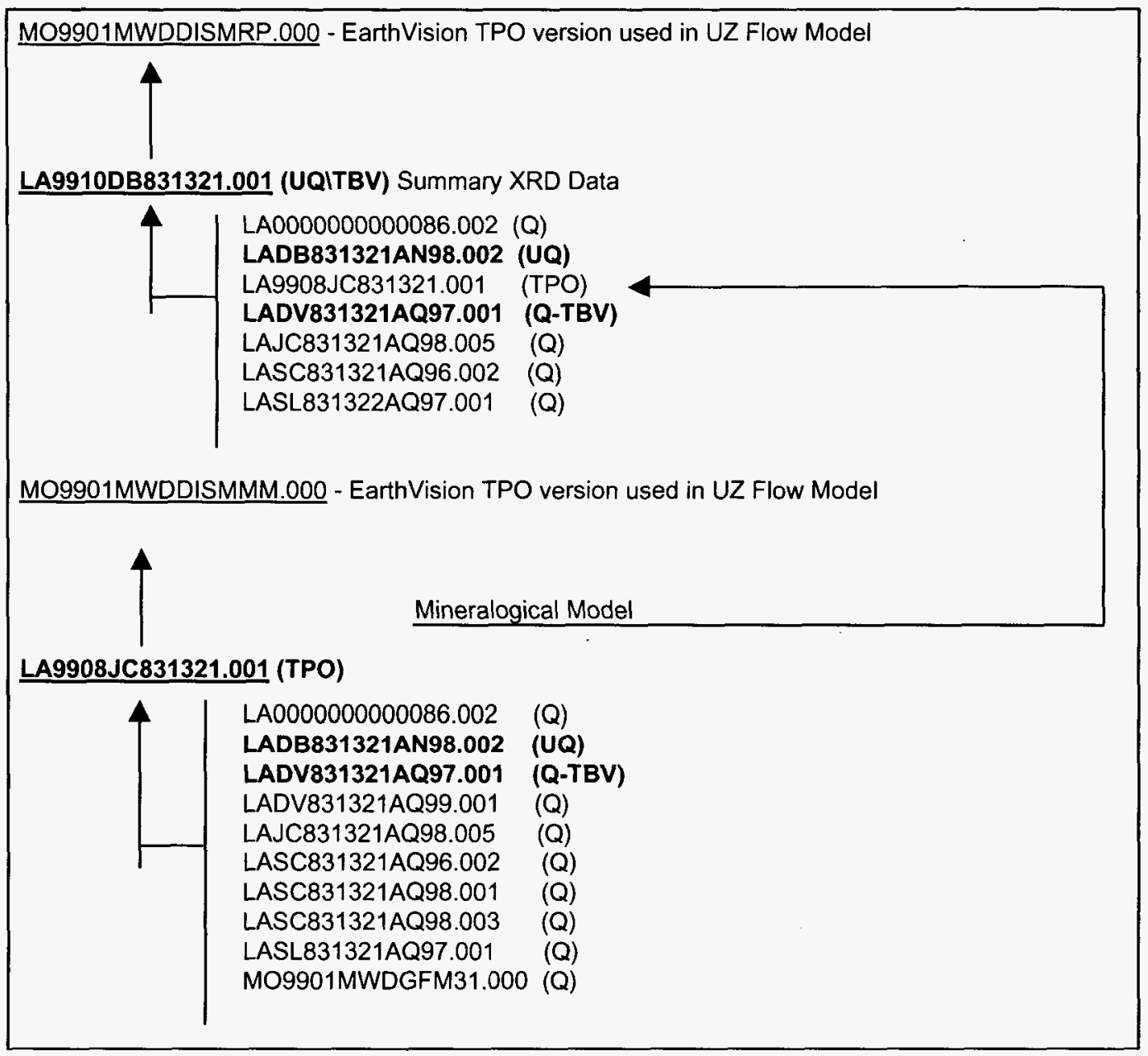

Figure 1. Relationship between XRD Source Data and Developed/Technical Product Output

\subsection{DATA QUALIFICATION TEAM}

The Responsible Manager for this data qualification task is Michael A. Jaeger.

\section{Chairperson}

Randy L. Bassett: Dr. Bassett has a Ph.D. in Geochemistry from Stanford University; master of science and bachelor of science degrees in Geology (Geochemistry Emphasis) from Texas Technological University and Baylor University. He has twenty-three years experience in aqueous and isotopic geochemistry and hydrogeology. He has worked on projects or has had funded research related to the nuclear waste site characterization in the Palo Duro Basin. This basin is a field site funded by the Nuclear Regulatory Commission to investigate unsaturated 
zone geochemical characterization and modeling, National Academy of Science Panel on Low Level Radioactive Waste, Hanford Expert Panel, Geochemistry Session Organizer for Waste Management Conferences, research projects on field tracer tests, isotopic fingerprinting, geochemical and transport modeling. He was formerly a professor at the University of Arizona, Department of Hydrology and Water Resources, teaching geochemistry, isotopic chemistry, and radioactive waste classes; and now is president of Geochemical Technologies Corp. He has had no involvement with the collection or processing of any YMP data.

\section{Chairperson}

Terry L. Steinborn: Dr. Steinborn has a B.A. (1968) in Chemistry with emphasis on inorganic and radiochemistry, and an M.S. (1972) and Ph.D. (1976) in Geology with emphasis in geochemistry and vocanology, and is a Professional Hydrogeologist, certified by the American Institute of Hydrology. He has 27 years of experience, most of it in activities related to nuclear and hazardous waste environmental issues. While at the Office of Nuclear Waste Isolation (Battelle Memorial Institute), he managed Site Performance Assessment and the Geochemistry Program. He served on the DOE-HQ Independent Review Team for WIPP, and worked with SNL on WIPP, the Greater Confinement Disposal Program, and SNL Site Environmental Restoration.

\section{Technical Representatives}

William Zelinski: Mr. Zelinski has a master of science degree in Geology from New Mexico Institute of Mining and Technology. He has twenty-two years experience in a variety of geoscience activities, including five years on the YMP, primarily creating computer models of geology and rock properties. Mr. Zelinski has had no involvement with the collection or processing of this data.

Richard A. Ayres: Mr. Ayres has a bachelor of science degree in Aeronautical Engineering from California State Polytechnic University and thirty-one years experience in commercial nuclear power. His experience includes quality assurance management for spent nuclear fuel storage and transportation systems, quality assurance management for nuclear engineering services, and nuclear power plant construction and testing. For the YMP, Mr. Ayres has researched and evaluated documents from various YMP databases, prepared reports, plans, letters and transmittal documents, and maintained status documents to facilitate and coordinate YMP data qualification. Mr. Ayres has had no involvement with the collection or processing of this data.

Robert W. Bonisolli: Mr. Bonisolli is a Data Qualification Team member. Mr. Bonisolli has a bachelor of science degree in Marine Engineering from Massachusetts Maritime Academy (1981) and Twenty-one years experience in nuclear power plant construction and operational support. Within the YMP, Mr. Bonisolli has conducted independent assessments such as the "Independent Assessment of the Office of Civilian Radioactive Waste Management (OCRWM)/M\&O Procurement Practices." Mr. Bonisolli has had no involvement with the collection or processing of this data.

Randy L. Bassett served as the original Chairperson for this data qualification effort. He performed the majority of research and was responsible for the initial reviews and assessments. 
Terry L. Steinborn succeeded Randy L. Bassett as Chairperson. He was responsible for editing and updating the report and brought the data qualification effort to completion.

\subsection{BACKGROUND}

The DTNs in Table 1 contain XRD data that were collected by LANL investigators beginning in the early 1980s and completed by 1986. Descriptions of the analytical methodologies for these data can be found in published LANL documents (Bish et al. 1996; Bish and Chipera 1986, 1989; Chipera et al. 1995; Bish and Vaniman 1985). Table 2 is an excerpt from a dataset in DTN LADB831321AN98.002 of mineral abundance analyses from core USW G-4 to illustrate the data content. The mineral abundance data are listed by depth in feet, and the depth value is generally treated as the sample number as well.

The Data Qualification Team determined that the principal assessment actions required for qualification of the analyses were that the core and other source material should be qualified, that sampling and analyses methods should be reviewed for technical adequacy, and software program POWD10 (Pennsylvania State University 1983), used in the XRD mineral analysis, should be baselined and retired.

The process used to obtain and control core in the early 1980s has been questioned in terms of adequate sample control and chain-of-custody. These concerns included the core storage and core sampling methods at the USGS Core Warehouse at Mercury, Nevada. The core in the USGS Core Warehouse was uncontrolled, and USGS personnel were not available for sampling, so individual investigators were required to collect their own samples. This lack of sample documentation and control was remedied when the core was relocated to the Sample Management Facility (SMF) at the Nevada Test Site, and controlled under approved procedures. The XRD mineral abundance data presented in DTN LADB831321AN98.002 are all from boreholes drilled under USGS supervision prior to 1986; and core from all of these boreholes were stored at the USGS Core Warehouse. Therefore, a review of coring, sample collection, and control methods was included in the technical assessment.

Drilling of boreholes for the YMP included standard drilling as well as coring; therefore, the resultant borehole material, if retained, was either drill cuttings or core material. In addition, occasionally small core plugs were obtained from the side of the borehole using a sidewall-coring device. The retained material was subsequently sent to the USGS Core Warehouse in Mercury, Nevada for storage. In the early 1980s, LANL investigators went to the USGS Core Warehouse to collect the samples for mineral XRD analyses, the results of which were included in the DTNs listed in Table 1. These samples were collected from whatever material was available: core, drill cuttings, or sidewall core. Separate qualification actions have been conducted to qualify the core itself. The qualification actions considered the collection, documentation, and control of the core from operations at the borehole to its current storage location at the SMF. Core from ten of the older USGS boreholes was qualified by Zelinski and Lum in CRWMS M\&O (2000a). Seven (7) of those boreholes are data sources in DTN LADB831321AN98.002 (Table 3). Intermittent core from UE J-13 and USW H-6, and all cuttings and sidewall core samples were not qualified by this action. The technical assessment in this DQR was limited to considering only source material that had been qualified in previous 
actions and to the intermittent core from USW H-6 which is evaluated in this DQR. A listing of material types contained in DTN LADB831321AN98.002 is given in Table 3.

Table 2. Sample Extraction of a Small Part of the Data Set for Well USW G-4 in SEP Table G-4s98163_010 in DTN LADB831321AN98.002. Illustrating the Data Type and Structure

Mineral abundance data results of core samples from USW G-4 determined using X-Ray Diffraction analysis, $01 / 02 / 1981$ to $11 / 01 / 1988$.

PARAMETERS:

SMECTITE ABUNDANCE

QUARTZ ABUNDANCE

CRISTOBALITE/OPAL ABUNDANCE

FELDSPAR ABUNDANCE

\begin{tabular}{|c|c|c|c|c|c|c|c|c|}
\hline $\begin{array}{l}\text { SAMPLE } \\
\text { NUMBER }\end{array}$ & $\begin{array}{l}\text { SMECTITE } \\
\text { ABUND. }\end{array}$ & $\begin{array}{l}\text { SMECTITE } \\
\text { UNCERT. }\end{array}$ & $\begin{array}{l}\text { QUARTZ } \\
\text { ABUND. }\end{array}$ & $\begin{array}{l}\text { QUARTZ } \\
\text { UNCERT. }\end{array}$ & $\begin{array}{l}\text { CRISTO. } \\
\text { ABUND. }\end{array}$ & $\begin{array}{l}\text { CRISTO. } \\
\text { UNCERT. }\end{array}$ & $\begin{array}{c}\text { FELDSPAR } \\
\text { ABUND. }\end{array}$ & $\begin{array}{r}\text { FELDSPAR } \\
\text { UNCERT. }\end{array}$ \\
\hline
\end{tabular}

\begin{tabular}{|c|c|c|c|c|c|c|c|c|}
\hline 47 & 2 & 1 & 2 & 1 & 28 & 5 & 70 & 10 \\
\hline 72 & $\sim 1$ & - & 2 & 1 & 28 & 5 & 70 & 10 \\
\hline 107 & - & - & 2 & 1 & 28 & 5 & 67 & 10 \\
\hline 123 & 25 & 10 & - & - & 32 & 5 & 40 & 10 \\
\hline 148 & 35 & 15 & - & - & 15 & 10 & - & - \\
\hline
\end{tabular}

FOOTNOTES: Abundance values are in weight percent. Sample number represents depth in feet. - indicates not detected. Tr. indicates trace (less than $0.5 \%$ ). All uncertainty data are valid within two standard deviations.

Clinoptilolite Abundance represents clinoptilolite/heulandite group mineral abundance. For Cristobalite, Opal-CT present in zeolitic tuff is reported as cristobalite. (a) =Calcite, (b) = analyzed using the Internal Standard Method, (c) = Hematite, $(d)=$ Cryptomelane. Blanks are intended.

Table 3. List of Boreholes in DTN LADB831321AN98.002, Material Type Analyzed, and Qualification Status of the Material

\begin{tabular}{|c|l|l|}
\hline Well & \multicolumn{1}{|c|}{ Material Type } & \multicolumn{1}{c|}{ Status } \\
\hline UE J-13 & Intermittent Core & Unqualified \\
\hline UE-25a\#1 & Continuous Core & Qualified (CRWMS M\&O 2000a) \\
\hline UE-25b\#1 & Continuous Core & Qualified (CRWMS M\&O 2000a) \\
\hline USW G-1 & Continuous Core & Qualified (CRWMS M\&O 2000a) \\
\hline USW G-2 & Continuous Core & Qualified (CRWMS M\&O 2000a) \\
\hline USW G-3 & Continuous Core & Qualified (CRWMS M\&O 2000a) \\
\hline USW GU-3 & Continuous Core & Qualified (CRWMS M\&O 2000a) \\
\hline USW G-4 & Continuous Core & Qualified (CRWMS M\&O 2000a) \\
\hline USW H6 & Intermittent Core & Unqualified \\
\hline UE-25 J-12 & Cuttings & Unqualified \\
\hline USW WT-1 & Cuttings & Unqualified \\
\hline USW H-3 & Cuttings, Sidewall Core & Unqualified \\
\hline USW H-4 & Cuttings, Sidewall Core & Unqualified \\
\hline USW WT-2 & Cuttings, Intermittent Core & Unqualified \\
\hline UE-25 p\#1 & Cuttings, Intermittent Core, Sidewall Core & Unqualified \\
\hline USW H-5 & Cuttings, Intermittent Core, Sidewall Core & Unqualified \\
\hline
\end{tabular}


The qualification effort completed by Zelinski and Lum (CRWMS M\&O 2000a) qualified only core material from boreholes with continuous core as noted in Table 3. For the reason of unreliable depth confirmation for cuttings and sidewall core, only the XRD mineral abundance data from samples of core will be qualified in this DQR. UE J-13 was drilled in the early 1960s and was cored intermittently, and USW H-6, drilled in 1982, also was cored only intermittently from 1091 to $4002 \mathrm{ft}$ depth. The seven boreholes listed below are the only wells from DTN LADB831321AN98.002 that were continuously cored, for which the core material has previously been qualified, and from which XRD samples were initially considered in this DQR (Table 4a) and represent analyses of at least 576 samples.

Table 4a. Boreholes with Previously Qualified Core from which Samples Were Collected by LANL

\begin{tabular}{|c|c|c|c|l|}
\hline Well & Spud Date & Completion Date & Total Depth & \multicolumn{1}{c|}{ Reference } \\
\hline UE-25a\#1 & $06 / 25 / 78$ & $09 / 02 / 78$ & 2501 & F.\&S. (1986a) \\
\hline UE-25b\#1 & $04 / 03 / 81$ & $09 / 22 / 81$ & 4002 & F.\&S. (1986b) \\
\hline USW G-1 & $03 / 12 / 80$ & $09 / 17 / 80$ & 6000 & F.\&S. (1987a) \\
\hline USW G-2 & $03 / 25 / 81$ & $10 / 24 / 81$ & 6006 & F.\&S. (1987a) \\
\hline USW G-3 & $01 / 08 / 82$ & $03 / 21 / 82$ & 5031 & F.\&S. (1987a) \\
\hline USW GU-3 & $01 / 26 / 82$ & $06 / 12 / 82$ & 2644 & F.\&S. (1987a) \\
\hline USW G-4 & $08 / 23 / 82$ & $01 / 13 / 83$ & 3003 & F.\&S. (1987a) \\
\hline
\end{tabular}

* Fenix and Scisson

In addition, the intermittent core from USW H-6 was evaluated by this report and found to be suitable for use in XRD analyses. Table $4 \mathrm{~b}$ summarizes the drilling information for this borehole.

Table 4b. Well USW H-6 Data

\begin{tabular}{|c|c|c|c|c|}
\hline Well & Spud Date & Completion Date & Total Depth & Reference \\
\hline USW H-6 & $08 / 07 / 82$ & $10 / 28 / 82$ & 4002 & F.\&S. (1987b) \\
\hline
\end{tabular}

All of the core samples from these boreholes were collected by LANL investigators prior to the transfer of the core to the SMF.

\section{QUALIFICATION METHODS}

The qualification method of technical assessment is used in this DQR to determine the appropriateness of sample collection, handling, and analysis methodologies, based on proven scientific procedures through a technical review of work done at LANL during the 1981 to 1986 time frame.

Technical Assessment-TWS-ESS-DP-16, Siemens X-ray Diffraction Procedure, Rev. 1, was written and implemented at LANL in 1982 and was the procedure followed in obtaining the data for DTN LADB831321AN98.002. The YMP QA procedure LANL-EES-DP-16, Siemens X-ray Diffraction Procedure, Rev. 5, was accepted by LANL in 1991 and was qualified for use on the YMP when the LANL program was qualified. 
An assessment of the records was conducted by the Data Qualification Team to determine if the work completed using the 1982 methods (TWS-ESS-DP-16) can be deemed technically correct and would have yielded comparable results to those obtained from using the YMP approved procedure accepted in 1991 (LANL-EES-DP-16).

An assessment was also done on the defensibility of sample handling. As part of the technical assessment, records were assembled that documented the sampling and transfer of core material used for analyses in DTN LADB831321AN98.002. The technical assessment considered the control and custody of samples from retrieval at the USGS Core Warehouse by LANL investigators to the LANL laboratory conducting the XRD analysis. The scientific notebooks and related records were examined by the Data Qualification Team to assess how reliably and defensibly the final mineral analyses can be deemed to represent the sampled core material.

Finally, the software package POWD10 (Pennsylvania State University 1983) was documented to current standards for the qualification of the data in DTN LADB831321AN98.002 and the verification of other DTNs. This POWD10 (Pennsylvania State University 1983) software qualification is accomplished using procedure AP-SI.1Q and documented by Software Requirements Document (RD) for POWD V10 (Bassett 2001a), Software Validation Test Plan (VTP) for POWD V10 (Bassett 2001b), and Software Validation Test Report (VTR) for POWD $V 10$ (Bassett 2001c). These actions resulted in the software package being placed on the YMP baseline and then immediately retired.

\subsection{EVALUATION CRITERIA}

The criteria that were applied in evaluating the qualification status of the LANL XRD mineral abundance data are identified below. These criteria were selected based on the considerations listed in procedure AP-SIII.2Q, Attachment 2 and the applicable qualification process attributes listed in procedure AP-SIII.2Q, Attachment 3. The criteria are:

1. Is there sufficient supporting documentation to ensure that sample data acquisition and sample handling procedures were adequate?

2. Are the XRD analytical methods reasonable and defensible in view of standard measurement and instrumentation practice at the time the data were collected, prior to the approved OCRWM/YMP QA procedures, and are they technically similar to the existing methods?

\subsection{RECOMMENDATION CRITERIA}

The following recommendation criteria will be considered in determining whether the status of the data should be changed to qualified.

1. The data adequately represent the properties of interest.

2. The data were collected using established procedures.

3. Uncertainties in the data were considered when determining if the data are appropriate for the intended use. 
Although these criteria were considered in determining whether the status of the data should be changed to qualified, the final recommendations of the Data Qualification Team were based on a preponderance of evidence

\section{EVALUATION RESULTS}

The evaluation results are described in the following subsections, each reflecting a qualification task previously described:

1. Section 3.1 provides a technical assessment of collection of the unqualified core from USW H-6.

2. Section 3.2 provides a technical assessment of the LANL core sample collection, handling and preparation for XRD analysis.

3. Section 3.3 provides an evaluation of methods employed to obtain XRD results at LANL during the time period of the analyses for mineral abundance reported in DTN LADB831321AN98.002.

\subsection{REVIEW OF CORE COLLECTION FOR USW H-6}

The core for USW H-6 has not been qualified in a separate action, therefore, the suitability of the core for XRD analysis was reviewed as part of this report. The collection, retrieval, and handling of the core for this borehole relate to Recommendation Criterion 1 as to whether the XRD results for USW H-6 are representative of the stated depths in the borehole.

The drilling history for the borehole is documented in Fenix and Scisson, Inc. (1987b). This reference includes a core record showing intervals cored and core recovery. A thorough review of available information for a number of boreholes, including USW H-6 (Spengler 2001, Page 5) has been compiled by D. C. Buesch of the USGS. The material reviewed included geophysical logs, core, cuttings, borehole video, core video and photographs, and previous lithologic descriptions. The purpose of the review was to prepare a detailed definition of the stratigraphic contacts in the borehole. This effort required a thorough review and correlation of the core to the other documentation. The review identified no anomalies that would indicate that the core currently stored at the SMF did not come from the intervals indicated on the core boxes.

The assessment by the Data Qualification Team concluded that the original documentation and the recent review by Buesch (Spengler 2001) provided sufficient documentation to determine that the core sampled for XRD analysis came from the intervals indicated in USW H-6. The depths attributed to each core run should be accurate to within +0.1 foot. The accuracy of the depths of the samples from within each core run used for XRD analysis should be only affected by the normal uncertainties introduced by coring operations (e.g., core loss within the run).

\subsection{REVIEW OF CORE SAMPLING AND SAMPLE PREPARATION FOR XRD ANALYSIS}

The data in DTN LADB831321AN98.002 are unqualified because they were collected prior to the approval of the OCRWM QA program. The Data Qualification Team decided that the 
process of sample collection from the core and sample preparation should be reviewed in detail because of concerns raised by previous reviews of similar information or processes. Here, we address first the samples examined and collected from core material stored in the USGS Core Warehouse in the early 1980 s.

After May 3, 1989, a series of USGS procedures became the approved implementation protocols for USGS data collection activities. The USGS began developing and implementing these procedures as early as 1983 , but they were not formally adopted by the USGS as part of the OCRWM QA program until 1989.

The core discussed in this DQR were all drilled prior to the 1989 QAPP (Table 4a). Although the drilling of the wells was under the guidance of the USGS with the purpose of providing geologic and hydrologic information for the Yucca Mountain area, field operations were directed by Fenix and Scisson Inc. (Fenix and Scisson, Inc. 1986a, 1986b, 1987a and 1987b), a contractor from Tulsa, Oklahoma.

Lack of control and documentation in the handling of some of the early core, including all core listed in Table 4a, were recognized as a potential issue and commented on in the U.S. Department of Energy (DOE) Waste Management Project Office (WMPO) letter titled "Use of Existing Geologic Samples and Related Data" (Gertz 1988). This letter stated that, "At this juncture, each participating organization is to proceed under the assumption that the existing core and derived data have not been qualified for use in licensing." The principal issues related to the "...method of handling, storage, and identification of core..."

This was followed by a WMPO QA Surveillance Report (SR-88-007) described in a letter from James Blaylock of WMPO to Larry Hayes, Technical Project Officer of Nevada Nuclear Waste Storage Investigation (NNWSI), of the USGS in May of 1988 (Blaylock 1988). This surveillance report documents the deficiencies in the drilling and coring operation, especially in the 1981-1983 time frame and specifically for the USW-G4 well, but is applicable to all NNWSI drilling activities. The surveillance report concludes a program review has found "...problems centered around the adequacy of procedure, lack of verification of activities performed at the drill site, inadequate sample identification, and improper handling, storage and transportation of the core to the core library and insufficient records," (Blaylock 1988).

The above concerns were addressed by the qualification of the core itself (e.g., the representativeness of existing stored core relative to the original material removed from the borehole) for ten boreholes in an earlier data qualification report (CRWMS M\&O 2000a) and in Section 3.1 of this report for USW H-6. As stated in that DQR (CRWMS M\&O 2000a), paper drill logs, geophysical run logs, downhole video cassettes, borehole stratigraphic contacts data, core observations and core photos for these ten boreholes were assembled and evaluated. Each form of evidence was evaluated for changes that reflected changes in rock properties that could be corroborated using the multiple forms of evidence. From this data corroboration, core identification and the control of core from the drill site to the SMF could be confirmed. Zelinski and Lum (CRWMS M\&O 2000a) were then able to conclude that the core from the ten boreholes were "qualified." 
Although the core from these 10 boreholes were qualified (CRWMS M\&O 2000a), the samples collected from the core for X-ray diffraction analysis during this period were not assessed. The Data Qualification Team determined that aspect of the process should be.reviewed as part of the technical assessment. The USGS Core Warehouse was unsupervised, and investigators were allowed to examine core alone and select their own samples for removal. Records were not maintained by the USGS identifying the core samples removed, rather, the individual investigators were responsible for documenting the sample removal. This was usually done by placing spacers in the core to mark the location of the removed sample and leaving some indication of the agency and investigator that removed the material.

The Data Qualification Team reviewed available electronic records and scientific notebooks that document the sample collection activities related to these DTNs. In addition, they have discussed the procedures with individuals actually involved in the collection of samples discussed in this $\mathrm{DQR}$. In general, for all the wells discussed in this $\mathrm{DQR}$, the procedures from sample acquisition by LANL personnel at the USGS Core Warehouse to analysis of received samples at LANL, are captured in the following outline:

1. Investigators from LANL traveled to the USGS Core Warehouse in Mercury, Nevada either during the drilling of the borehole of interest as core was being transferred, or shortly thereafter, to examine the core.

2. The investigators then examined the core, identified intervals to be removed as samples, described the lithology of the sampling location, removed the samples, placed a labeled wooden block in the place of the removed sample, placed samples in plastic bags, and left them for shipping to LANL by USGS personnel.

3. The samples were received by the Shipping and Receiving Department at LANL from whom the LANL investigators retrieved them, and took them to the lab at Area TA-33.

4. At the time the samples were to be analyzed, the investigators would go to the sample storage area, retrieve the samples, and give them to a technician for sample preparation. The technician would take the samples from their containers, crush enough of the sample using a crusher and shatterbox, place each sample in a vial, label it for powder X-ray diffraction analysis, and take it to the XRD lab in the same building.

5. Samples were then analyzed in the XRD lab, the diffractograms were printed and examined for mineral identification and mineral abundance. The diffractograms and vials were archived for future examination.

\section{Overview of Qualification Strategy}

At the time the samples were collected for DTN LADB831321AN98.002, there was only a general LANL procedure in place, TWS-G6-1/79-24, NTS Core Petrography Procedure, Rev. 0, to govern the collection activities. In the absence of defensible chain-of-custody documentation to provide sample traceability from core to laboratory, we will describe the preponderance of evidence that can be relied upon to ensure that the samples were collected correctly and that the 
data resulting from analyses of these samples are in fact reliable and defensible. The Data Qualification Team used the following lines of evidence to support this contention:

1. The samples were collected by a small cadre of investigators (Table 5) working essentially in the same research group, using methods that clearly labeled and identified the samples in the warehouse at the point of collection. The samples were described on location and the information was entered in scientific notebooks.

2. The SMF has examined and tabulated material in the core boxes that identifies locations in each core box from which core have been removed. This tabulation was used in this DQR for establishing traceability.

3. The samples were packaged sequentially and transported in bulk, so that the correct identification was likely preserved.

4. Handling and transfer of samples was minimal.

5. Scientific notebooks have entries identifying sample receipt at LANL and transfer to the XRD lab. XRD analysis of the samples was sufficiently well documented and controlled that any lost or mixed-up samples would have been detected.

6. Sample numbering is consistent, because the depth interval from which the sample was removed became the sample number. This identifier remained the same from the descriptions in the USGS Core Warehouse to the report of analysis from the XRD lab.

The samples listed in the DTN are the samples analyzed by XRD; therefore, this group of samples became the reference list.

Table 5. Investigators Involved in the Actual Sample Description and Collection

\begin{tabular}{|c|c|l|}
\hline Well & Investigator(s) & \multicolumn{1}{|c|}{ Reference for the Sample Descriptions } \\
\hline UE J-13 & H, Be & $\begin{array}{l}\text { Core sample descriptions for each sample published in LA-7563-MS } \\
\text { by Heiken and Bevier (1979). }\end{array}$ \\
\hline UE-25a\#1 & H, S & $\begin{array}{l}\text { Core descriptions for 35 of the 47 samples as listed in scientific } \\
\text { notebook TWS-G-9-3/80-10 (Sykes 2001a), and all samples were } \\
\text { described in detail in Sykes et al. (1979). }\end{array}$ \\
\hline UE-25b\#1 & B,V & Only general descriptions located. \\
\hline USW G-1 & S & Only general descriptions located. \\
\hline USW G-2 & B,V,C & $\begin{array}{l}\text { Core descriptions for 89 of the 136 samples are described in two } \\
\text { memoranda from Caporuscio (1981 a, b). }\end{array}$ \\
\hline USW G-3 & V & $\begin{array}{l}\text { Core descriptions for most samples are found in the scientific } \\
\text { notebook TWS-GS-8/79-50 (Vaniman 2001). }\end{array}$ \\
\hline USW GU-3 & B,V,C & $\begin{array}{l}\text { Core descriptions for 103 of the 114 samples listed in this DTN are in } \\
\text { scientific notebook TWS-GS-8/79-50 (Vaniman 2001). }\end{array}$ \\
\hline
\end{tabular}


Table 5. Investigators Involved in the Actual Sample Description and Collection (Continued)

\begin{tabular}{|c|c|l|}
\hline Well & Investigator(s) & \multicolumn{1}{c|}{ Reference for the Sample Descriptions } \\
\hline USW G-4 & B,V,C & $\begin{array}{l}\text { Core descriptions for 92 of the 96 samples listed in this DTN are in } \\
\text { scientific notebook TWS-ESS-1-10/82-25 (Byers 2001). }\end{array}$ \\
\hline USW H6 & L & $\begin{array}{l}\text { Core descriptions for each sample documented in scientific notebook } \\
\text { TWS-EES-1-11/82-3 (Levy 1998). }\end{array}$ \\
NOTES: Investigator Key \\
B = David Bish \\
Be = Mary Lou Bevier \\
C = F.A. Caporuscio \\
H = Grant H. Heiken \\
L = Schon Levy \\
S = Joseph R. Smyth \\
V = D.T. Vaniman
\end{tabular}

\subsubsection{Records}

In view of the fact that a complete reconstruction of the relevant records is not possible, the Data Qualification Team has assembled what it considers to be the key documentation. Some of the records are published LANL reports; some are notations in scientific notebooks. Other records undoubtedly were made, but have been lost or discarded over the more than 20 years since collection. The Data Qualification Team assessed the existing records and determined that sufficient documentation does exist to defend the quality of the data.

The records trail is summarized in Tables 6a-e for the samples from five of the wells qualified here. The tables consist of eight columns arranged to depict chronology from left to right. The samples tabulated in the DTN were analyzed by XRD for mineral abundance and this is the information given in the DTN. The sample list in the DTN therefore serves as the reference list and represents the last step in the sample chronology. Column 8 (Tables 6a through 6e) identifies all the samples in the DTN LADB831321AN98.002 for the five wells reviewed, by depth, which is the sample number. Columns 1 through 4 represent the information obtained from the SMF. Column 5 denotes references to publications or scientific notebooks in which sample descriptions were made at the time of sample collection. Columns 6 and 7 provide references to scientific notebooks in which either the receipt of a sample at LANL or transfer of a sample to the XRD or thin section lab at LANL is noted. Subsequent sections in this DQR will refer to this sample chronology from Tables 6a through 6e. Records for samples were not adequate to generate a similar table for well USW H6. The available records were reviewed and assessed and it was felt that sufficient evidence exists to justify qualification of the data from those samples. 
Table 6a. Detail Mapping of Samples from Collection to Analysis for UE-25b\#1

\begin{tabular}{|c|c|c|c|c|c|c|c|}
\hline $\begin{array}{l}\text { Sample } \\
\text { From } \\
\text { (ft) }^{1}\end{array}$ & $\begin{array}{l}\text { Sample } \\
\text { To }(\mathrm{ft})^{1}\end{array}$ & \begin{tabular}{|c|} 
Sample \\
Designator
\end{tabular} & $\begin{array}{c}\text { Sample Management } \\
\text { Facility Records }^{1}\end{array}$ & $\begin{array}{c}\text { Reference for } \\
\text { Sample Visual } \\
\text { Description }\end{array}$ & $\begin{array}{c}\text { Reference } \\
\text { for Notation } \\
\text { of Sample } \\
\text { Transmittal } \\
\text { / Receipt }\end{array}$ & $\begin{array}{c}\text { Reference } \\
\text { for Notation } \\
\text { of XRD or } \\
\text { Thin } \\
\text { Section } \\
\end{array}$ & $\begin{array}{c}\text { DTN } \\
\text { Sample } \\
\text { Depth (ft) } \\
\text { for XRD } \\
\text { Analyses at } \\
\text { LANL }^{3}\end{array}$ \\
\hline 2401.8 & 2402.4 & $S$ & $\begin{array}{l}\text { LANL - ESS-1, O.R. 10- } \\
22-81\end{array}$ & 4 & 5 & 6 & 2402 \\
\hline 2449.5 & 2450.0 & $S$ & $\begin{array}{l}\text { LANL - ESS-1, O.R. } \\
\text { Crowe } 10-22-81\end{array}$ & 4 & 5 & 6 & 2450 \\
\hline 2525.0 & 2525.4 & $S$ & $\begin{array}{l}\text { LANL ESS-1, O.R. } \\
\text { Crowe 10/22/81 }\end{array}$ & 4 & 5 & 6 & 2525 \\
\hline 2596.3 & 2596.8 & $s$ & $\begin{array}{l}\text { LANL ESS-1, O.R. } \\
\text { Crowe 10/22/81 }\end{array}$ & 4 & 5 & 6 & 2596 \\
\hline 2651.5 & 2651.8 & $S$ & $\begin{array}{l}\text { LANL ESS-1, O.R. 10- } \\
22-81\end{array}$ & 4 & 5 & 6 & 2651 \\
\hline 2737.4 & 2737.7 & $S$ & $\begin{array}{l}\text { LANL-ESS-1, O.R. 10- } \\
22-81\end{array}$ & 4 & 5 & 6 & 2737 \\
\hline 2831.8 & 2832.2 & $S$ & $\begin{array}{l}\text { LANL ESS-1, O.R. 10- } \\
22-81\end{array}$ & 4 & 5 & 6 & 2832 \\
\hline 2846.7 & 2846.9 & $S$ & USGS BEM, O.R. NR & 4 & & 6 & 2847 \\
\hline 2855.0 & 2855.2 & $s$ & LANL ESS-1, 10-22-81 & 4 & 5 & 6 & 2855 \\
\hline 2866.5 & 2867.1 & $S$ & $\begin{array}{l}\text { LANL ESS-1, O.R. 10- } \\
22-81\end{array}$ & 4 & 5 & 6 & 2867 \\
\hline 2878.9 & 2879.3 & $\mathrm{~S}$ & \begin{tabular}{|l|} 
O.R. N.R. \\
\end{tabular} & 4 & 5 & 6 & 2879 \\
\hline 2918.8 & 2919.0 & $S$ & $\begin{array}{l}\text { LANL - ESS-1, O.R. 10- } \\
22-81\end{array}$ & 4 & 5 & 6 & 2919 \\
\hline 2946.3 & 2946.6 & S & $\begin{array}{l}\text { LANL ESS-1, O.R. 10- } \\
21-81\end{array}$ & 4 & 5 & 6 & 2946 \\
\hline 2953.5 & 2953.9 & $S$ & $\begin{array}{l}\text { LANL ESS-1, O.R. 10- } \\
22-81\end{array}$ & 4 & 5 & 6 & 2953 \\
\hline 2987.8 & 2988.2 & $s$ & $\begin{array}{l}\text { LANL ESS-1, O.R. 10- } \\
22-81\end{array}$ & 4 & 5 & 6 & 2988 \\
\hline 3050.5 & 3050.7 & $S$ & $\begin{array}{l}\text { LANL ESS-1, O.R. 10- } \\
22-81\end{array}$ & 4 & 5 & 6 & 3050 \\
\hline 3091.9 & 3092.2 & $S$ & $\begin{array}{l}\text { LANL ESS-1, O.R. 10- } \\
22-81\end{array}$ & 4 & 5 & 6 & Fracture \\
\hline 3094.8 & 3095.0 & $\mathrm{~s}$ & $\begin{array}{l}\text { LANL ESS-1, O.R. 10- } \\
22-81\end{array}$ & 4 & 5 & 6 & 3095 \\
\hline 3097.6 & 3098.0 & $\mathrm{~s}$ & $\begin{array}{l}\text { LANL ESS-1, O.R. 10- } \\
22-81\end{array}$ & 4 & 5 & 6 & 3098 \\
\hline 3127.8 & 3128.1 & $S$ & $\begin{array}{l}\text { LANL ESS-1, O.R. 10- } \\
22-81\end{array}$ & 4 & 5 & 6 & 3128 \\
\hline 3127.8 & 3128.1 & $S$ & $\begin{array}{l}\text { LANL ESS-1, O.R. 10- } \\
22-81\end{array}$ & 4 & 5 & 6 & Fracture \\
\hline 3163.0 & 3163.4 & $S$ & $\begin{array}{l}\text { LANL ESS-1, O.R. 10- } \\
22-81\end{array}$ & 4 & 5 & 6 & 3163 \\
\hline 3163.0 & 3163.4 & $S$ & $\begin{array}{l}\text { LANL ESS-1, O.R. 10- } \\
22-81\end{array}$ & 4 & 5 & 6 & Fracture \\
\hline
\end{tabular}


Table 6a. Detail Mapping of Samples from Collection to Analysis for UE-25b\#1 (Continued)

\begin{tabular}{|c|c|c|c|c|c|c|c|}
\hline $\begin{array}{l}\text { Sample } \\
\text { From } \\
\text { (ft) }\end{array}$ & $\begin{array}{l}\text { Sample } \\
\text { To }(\mathrm{ft})^{1}\end{array}$ & $\begin{array}{c}\text { Sample } \\
\text { Designator }\end{array}$ & $\begin{array}{c}\text { Sample Management } \\
\text { Facility Records }^{1}\end{array}$ & $\begin{array}{c}\text { Reference for } \\
\text { Sample Visual } \\
\text { Description }\end{array}$ & $\begin{array}{c}\text { Reference } \\
\text { for Notation } \\
\text { of Sample } \\
\text { Transmittal } \\
\text { I Receipt }\end{array}$ & \begin{tabular}{|c|} 
Reference \\
for Notation \\
of XRD or \\
Thin \\
Section \\
\end{tabular} & $\begin{array}{c}\text { DTN } \\
\text { Sample } \\
\text { Depth (ft) } \\
\text { for XRD } \\
\begin{array}{c}\text { Analyses at } \\
\text { LANL }^{3}\end{array} \\
\end{array}$ \\
\hline 3184.7 & 3185.2 & $S$ & $\begin{array}{l}\text { LANL ESS-1, O.R. 10- } \\
22-81\end{array}$ & 4 & 5 & 6 & 3185 \\
\hline 3184.7 & 3185.2 & $S$ & $\begin{array}{l}\text { LANL ESS-1, O.R. 10- } \\
22-81\end{array}$ & 4 & 5 & 6 & Fracture \\
\hline \multirow[t]{2}{*}{3091.9} & 3092.2 & $S$ & $\begin{array}{l}\text { LANL ESS-1, O.R. 10- } \\
22-81\end{array}$ & 4 & 5 & 6 & 3092 \\
\hline & & & & 4 & & 6 & 3196 \\
\hline 3222.4 & 3222.6 & S & $\begin{array}{l}\text { LANL ESS-1, O.R. 10- } \\
22-81\end{array}$ & 4 & 5 & 6 & 3222 \\
\hline 3225.2 & 3225.4 & $S$ & $\begin{array}{l}\text { LANL ESS-1, O.R. 10- } \\
22-81\end{array}$ & 4 & 5 & 6 & 3225 \\
\hline 3256.8 & 3257.2 & $S$ & $\begin{array}{l}\text { LANL ESS-1, O.R. 10- } \\
22-81\end{array}$ & 4 & 5 & 6 & 3257 \\
\hline 3267.4 & 3267.6 & $S$ & $\begin{array}{l}\text { LANL ESS-1, O.R. 10- } \\
22-81\end{array}$ & 4 & 5 & 6 & 3267 \\
\hline 3292.7 & 3298.2 & $s$ & $\begin{array}{l}\text { LANL ESS-1, O.R. 10- } \\
22-81\end{array}$ & 4 & 5 & 6 & 3298 \\
\hline 3325.9 & 3326.3 & $S$ & $\begin{array}{l}\text { LANL ESS-1, O.R. 10- } \\
\text { 22-81 }\end{array}$ & 4 & 5 & 6 & 3326 \\
\hline 3361.7 & 3362.1 & $S$ & LANL, ESS-1, 10-27-81 & 4 & 5 & 6 & 3362 \\
\hline 3373.8 & 3374.3 & S & $\begin{array}{l}\text { LANL ESS-1, O.R. 10- } \\
22-81\end{array}$ & 4 & 5 & 6 & 3374 \\
\hline 3393.4 & 3393.7 & S & $\begin{array}{l}\text { LANL ESS-1, O.R. } 10- \\
22-81\end{array}$ & 4 & 5 & 6 & 3393 \\
\hline 3401.4 & 3401.7 & S & $\begin{array}{l}\text { LANL ESS-1, O.R. 10- } \\
22-81\end{array}$ & 4 & 5 & 6 & 3401 \\
\hline 3459.4 & 3459.8 & $S$ & $\begin{array}{l}\text { LANL ESS-1, O.R. 2-2- } \\
81\end{array}$ & 4 & 5 & 6 & 3459 \\
\hline 3469.2 & 3469.7 & $S$ & $\begin{array}{l}\text { LANL ESS-1, O.R. 10- } \\
22-81\end{array}$ & 4 & 5 & 6 & 3469 \\
\hline 3506.3 & 3506.8 & $S$ & $\begin{array}{l}\text { LANL ESS-1, O.R. 10- } \\
22-81\end{array}$ & 4 & 5 & 6 & 3506 \\
\hline 3529.9 & 3530.3 & $S$ & $\begin{array}{l}\text { LANL ESS-1, O.R. 10- } \\
22-81\end{array}$ & 4 & 5 & 6 & 3530 \\
\hline 3529.9 & 3530.3 & $s$ & $\begin{array}{l}\text { LANL ESS-1, O.R. 10- } \\
22-81\end{array}$ & 4 & 5 & 6 & Fracture \\
\hline 3548.0 & 3548.5 & $S$ & $\begin{array}{l}\text { LANL ESS-1, O.R. } 10- \\
22-81\end{array}$ & 4 & 5 & 6 & 3548 \\
\hline 3548.0 & 3548.5 & $S$ & $\begin{array}{l}\text { LANL ESS-1, O.R. 10- } \\
22-81\end{array}$ & 4 & 5 & 6 & Inclusion \\
\hline 3571.0 & 3571.7 & $S$ & $\begin{array}{l}\text { LANL ESS-1, O.R. 10- } \\
22-81\end{array}$ & 4 & 5 & 6 & 3571 \\
\hline
\end{tabular}


Table 6a. Detail Mapping of Samples from Collection to Analysis for UE-25b\#1 (Continued)

\begin{tabular}{|c|c|c|c|c|c|c|c|}
\hline $\begin{array}{l}\text { Sample } \\
\text { From } \\
\text { (ft) }\end{array}$ & $\begin{array}{l}\text { Sample } \\
\text { To }(\mathrm{ft})^{1}\end{array}$ & \begin{tabular}{|c|} 
Sample \\
Designator $^{1,2}$
\end{tabular} & $\begin{array}{c}\text { Sample Management } \\
\text { Facility Records }^{1}\end{array}$ & $\begin{array}{c}\text { Reference for } \\
\text { Sample Visual } \\
\text { Description }\end{array}$ & $\begin{array}{c}\text { Reference } \\
\text { for Notation } \\
\text { of Sample } \\
\text { Transmittal } \\
\text { / Receipt }\end{array}$ & $\begin{array}{c}\text { Reference } \\
\text { for Notation } \\
\text { of XRD or } \\
\text { Thin } \\
\text { Section }\end{array}$ & $\begin{array}{l}\text { DTN } \\
\text { Sample } \\
\text { Depth (ft) } \\
\text { for XRD } \\
\begin{array}{c}\text { Analyses at } \\
\text { LANL }^{3}\end{array} \\
\end{array}$ \\
\hline 3572.2 & 3572.4 & s & $\begin{array}{l}\text { LANL ESS-1, O.R. 10- } \\
22-81\end{array}$ & 4 & 5 & 6 & 3572 \\
\hline 3572.2 & 3572.4 & s & $\begin{array}{l}\text { LANL ESS-1, O.R. 10- } \\
22-81\end{array}$ & 4 & 5 & 6 & Inclusion \\
\hline 3601.9 & 3602.5 & $s$ & $\begin{array}{l}\text { LANL ESS-1, O.R. 10- } \\
22-81\end{array}$ & 4 & 5 & 6 & 3602 \\
\hline 3601.9 & 3602.5 & s & $\begin{array}{l}\text { LANL ESS-1, O.R. 10- } \\
22-81\end{array}$ & 4 & 5 & 6 & Fracture \\
\hline 3660.2 & 3660.7 & S & $\begin{array}{l}\text { LANL ESS-1, O.R. 10- } \\
22-81\end{array}$ & 4 & 5 & 6 & 3660 \\
\hline 3660.2 & 3660.7 & S & $\begin{array}{l}\text { LANL ESS-1, O.R. 10- } \\
22-81\end{array}$ & 4 & 5 & 6 & Fracture \\
\hline 3707.9 & 3708.2 & $s$ & LANL, O.R 10-22-81 & 4 & 5 & 6 & 3708 \\
\hline 3766.8 & 3767.2 & $S$ & $\begin{array}{l}\text { LANL ESS-1, O.R. 10- } \\
22-81\end{array}$ & 4 & 5 & 6 & 3767 \\
\hline 3791.5 & 3792.0 & S & $\begin{array}{l}\text { LANL ESS-1, O.R. 10- } \\
22-81\end{array}$ & 4 & 5 & 6 & 3792 \\
\hline 3835.0 & 3835.4 & $s$ & $\begin{array}{l}\text { LANL ESS-1, O.R. 10- } \\
22-81\end{array}$ & 4 & 5 & 6 & 3835 \\
\hline 3880.6 & 3880.7 & S & $\begin{array}{l}\text { LANL ESS-1, O.R. 10- } \\
22-81\end{array}$ & 4 & 5 & 6 & 3880 \\
\hline 3901.4 & 3901.5 & $S$ & $\begin{array}{l}\text { LANL ESS-1, O.R. 10- } \\
22-81\end{array}$ & 4 & 5 & 6 & 3901 \\
\hline 3902.7 & 3902.9 & $s$ & $\begin{array}{l}\text { LANL ESS-1, O.R. 10- } \\
22-81\end{array}$ & 4 & 5 & 6 & 3902 \\
\hline 3904.1 & 3904.4 & S & $\begin{array}{l}\text { LANL ESS-1, O.R. 10- } \\
22-81\end{array}$ & 4 & 5 & 6 & 3904 \\
\hline & & & & 4 & & 6 & 3910 \\
\hline 3926.3 & 3926.5 & $s$ & $\begin{array}{l}\text { LANL ESS-1, O.R. 10- } \\
22-81\end{array}$ & 4 & 5 & 6 & 3926 \\
\hline 3956.1 & 3956.4 & s & $\begin{array}{l}\text { LANL ESS-1, Block } \\
\text { Shows wrong }\end{array}$ & 4 & 5 & 6 & 3956 \\
\hline 3963.5 & 3963.8 & $s$ & $\begin{array}{l}\text { LANL ESS-1, O.R. 10- } \\
22-81\end{array}$ & 4 & 5 & 6 & 3963 \\
\hline 3987.7 & 3988.1 & $s$ & $\begin{array}{l}\text { LANL ESS-1, O.R. 10- } \\
22-81\end{array}$ & 4 & 5 & 6 & 3988 \\
\hline 3987.7 & 3988.1 & $S$ & $\begin{array}{l}\text { LANL ESS-1, O.R. 10- } \\
22-81\end{array}$ & 4 & 5 & 6 & Fracture \\
\hline NOTES: & \multicolumn{7}{|c|}{$\begin{array}{l}1 \text { From SMF (Finnegan 2001). } \\
2 \text { Standard whole round core (S). } \\
3 \text { DTN LADB831321AN98.002 SEP (Site Engineering Properties) Table S98163_011. } \\
{ }^{4} \text { Report by Caporuscio et al. 1982. LA-9255-MS; General description, not sample specific. } \\
5 \text { Scientific Notebook TWS-G-9-6/81-9 sample specific (Caporuscio 2001a). } \\
{ }^{6} \text { No LANL Scientific Notebook has been located that contains the reference of sending san }\end{array}$} \\
\hline
\end{tabular}


Table 6b. Detailed Mapping of Samples from Collection to Analysis for USW G-1

\begin{tabular}{|c|c|c|c|c|c|c|c|}
\hline $\begin{array}{l}\text { Sample } \\
\text { From } \\
\text { (ft) }\end{array}$ & $\begin{array}{l}\text { Sample } \\
\text { To }(\mathrm{ft})^{1}\end{array}$ & $\begin{array}{c}\text { Sample } \\
\text { Designator }\end{array}$ & $\begin{array}{l}\text { Sample Management } \\
\text { Facility Records }^{1}\end{array}$ & \begin{tabular}{|c} 
Reference for \\
Sample Visual \\
Description
\end{tabular} & $\begin{array}{c}\text { Reference } \\
\text { for Notation } \\
\text { of Sample } \\
\text { Transmittal } \\
\text { / Receipt }\end{array}$ & $\begin{array}{c}\text { Reference } \\
\text { for Notation } \\
\text { for XRD or } \\
\text { Thin } \\
\text { Section }\end{array}$ & $\begin{array}{c}\text { DTN } \\
\text { Sample } \\
\text { Depth (ft) } \\
\text { for XRD } \\
\text { Analyses at } \\
\text { LANL }^{3}\end{array}$ \\
\hline 292.2 & 292.4 & $\mathrm{~s}$ & $\begin{array}{l}\text { LASL(block) LANL } \\
\text { Smyth - OR. } 9 / 24 / 80\end{array}$ & $\mathrm{G} 4, \mathrm{G} 5,6$ & 6 & & 292 \\
\hline 352.5 & & $S$ & $\begin{array}{l}\text { X-ray chip, LASL, } \\
\text { Smyth, 9/24/80 O.R. }\end{array}$ & $\mathrm{G} 4, \mathrm{G} 5,6$ & 6 & & 352 \\
\hline 399.8 & & s & $\begin{array}{l}\text { LASL, O.R. Smyth, } \\
\text { 9/24/80 TS/XR }\end{array}$ & G4, G5,6 & 6 & & 399 \\
\hline 450.4 & 450.6 & $\mathrm{~s}$ & O.R. Smyth $9 / 24 / 80$ & $\mathrm{G} 4, \mathrm{G} 5,6$ & 6 & & 450 \\
\hline 553.2 & & $\mathrm{~s}$ & $\begin{array}{l}\text { X-ray chip, LASL, O.R. } \\
1 / 24 / 80 \text {, "SrHH(Cannot } \\
\text { read O.R. very well)" }\end{array}$ & $\mathrm{G} 4, \mathrm{G} 5,6$ & 6 & & 553 \\
\hline 618.7 & 619.0 & $S$ & $\begin{array}{l}\text { LASL XR/TS, O.R. } \\
\text { Smyth 9/24/80 } \\
\end{array}$ & G4, G5,6 & 6 & & 619 \\
\hline 673.5 & & S & $\begin{array}{l}\text { X-ray, O.R. LASL, No } \\
\text { removal date }\end{array}$ & $\mathrm{G} 4, \mathrm{G} 5,6$ & 6 & & 673 \\
\hline 722.9 & 723.2 & $S$ & $\begin{array}{l}\text { LASL 6-9, O.R. Smythe, } \\
9 / 24 / 80\end{array}$ & $\mathrm{G} 4, \mathrm{G} 5,6$ & 6 & & 722 \\
\hline 757.4 & 757.7 & $S$ & $\begin{array}{l}\text { LASL G9, O.R. Smyth } \\
9 / 2 / 4 / 80\end{array}$ & G4, G5,6 & 6 & & 757 \\
\hline 819.7 & & $S$ & X-ray, LASL, No date & $\mathrm{G} 4, \mathrm{G} 5,6$ & 6 & & 819 \\
\hline 874.5 & 874.6 & $S$ & $\begin{array}{l}\text { LASL G-9, O.R. Smyth, } \\
9 / 24 / 80\end{array}$ & G4, G5,6 & 6 & & 874 \\
\hline 936.8 & 936.9 & $S$ & $\begin{array}{l}\text { LASL,TS/XR,O.R. } \\
\text { Smyth, 9/28/80 } \\
\end{array}$ & G4, G5,6 & 6 & & 936 Vein \\
\hline 995.5 & & $S$ & $\begin{array}{l}\text { X-ray, LASL, Smyth } \\
\text { 9/24/80, sitting on top of } \\
\text { piece from previous line }\end{array}$ & $\mathrm{G} 4, \mathrm{G} 5,6$ & 6 & & 995 \\
\hline 1063.0 & 1063.2 & $s$ & $\begin{array}{l}\text { LASL G-9, O.R. Smyth } \\
9 / 24 / 80\end{array}$ & G4, G5,6 & 6 & & 1063 \\
\hline 1104.3 & & $S$ & $\begin{array}{l}\text { LASL, O.R. Smyth, } \\
\text { 9/24/80 }\end{array}$ & $\mathrm{G} 4, \mathrm{G} 5,6$ & 6,8 & & 1104 \\
\hline 1123.6 & 1123.7 & $s$ & LLNL, No date on O.R. & G4, G5 & & & 1123 \\
\hline 1179.0 & 1179.2 & $s$ & $\begin{array}{l}\text { LASL, O.R. Vine, } \\
6 / 20 / 80 \\
\end{array}$ & G4, G5 & 6,7 & 7,9 & 1179 \\
\hline 1191.6 & 1191.9 & $s$ & $\begin{array}{l}\text { LASL G-9, O.R. Vine, } \\
6 / 20 / 80\end{array}$ & G4, G5 & 6,7 & 7,9 & 1191 \\
\hline 1239.8 & 1240.6 & $\mathrm{~s}$ & $\begin{array}{l}\text { LASL G-9, O.R. Vine, } \\
\text { "record unreadable" }\end{array}$ & G4, G5 & 6,7 & 7,9 & 1240 \\
\hline Note 11 & & & . & G4, G5 & 7 & 7,9 & 1274 \\
\hline 1281.8 & 1282.0 & $S$ & $\begin{array}{l}\text { LANL B. Carlos: } \\
\text { overlaps next piece }\end{array}$ & G4, G5 & 7,8 & 7,9 & 1281 \\
\hline 1285.7 & 1286.0 & $s$ & LASL G-9, O.R. 6/20/80 & G4, G5 & 6,7 & 7,9 & 1286 \\
\hline Note 11 & & & & G4, G5 & 7 & 7,9 & 1319 \\
\hline Note 11 & & & & G4, G5 & 7 & 7,9 & 1341 \\
\hline 1356.0 & 1356.3 & $S$ & $\begin{array}{l}\text { LANL, B. Carlos, no } \\
\text { O.R. }\end{array}$ & G4, G5 & 7 & 7,9 & 1357 \\
\hline
\end{tabular}


Table 6b. Detailed Mapping of Samples from Collection to Analysis for USW G-1 (Continued)

\begin{tabular}{|c|c|c|c|c|c|c|c|}
\hline $\begin{array}{l}\text { Sample } \\
\text { From } \\
\text { (ft) })^{1}\end{array}$ & $\begin{array}{l}\text { Sample } \\
\text { To (ft) }\end{array}$ & $\begin{array}{c}\text { Sample } \\
\text { Designator }\end{array}$ & $\begin{array}{l}\text { Sample Management } \\
\text { Facility Records }^{1}\end{array}$ & $\begin{array}{c}\text { Reference for } \\
\text { Sample Visual } \\
\text { Description }\end{array}$ & \begin{tabular}{|c|} 
Reference \\
for Notation \\
of Sample \\
Transmittal \\
/ Receipt
\end{tabular} & \begin{tabular}{|c|} 
Reference \\
for Notation \\
for XRD or \\
Thin \\
Section
\end{tabular} & \begin{tabular}{|c|} 
DTN \\
Sample \\
Depth (ft) \\
for XRD \\
Analyses at \\
LANL $^{3}$ \\
\end{tabular} \\
\hline 1392.0 & 1392.3 & $S$ & $\begin{array}{l}\text { LASL G-9, O.R. Vine, } \\
6 / 20 / 80\end{array}$ & G4, G5 & 6,7 & 7,9 & 1392 \\
\hline Note 11 & & & & G4, G5 & 7 & 7,9 & 1400 \\
\hline 1491.9 & 1492.0 & S & $\begin{array}{l}\text { LANL, Vine, O.R. } \\
6 / 20 / 80\end{array}$ & G4 & 6,7 & 7,9 & 1492 \\
\hline 1539.5 & 1539.7 & $S$ & $\begin{array}{l}\text { LANL, O.R. Vine, } \\
6 / 20 / 80 \text {, removed from } \\
\text { rubble in previous } \\
\text { interval }\end{array}$ & G4 & 6,7 & 7,9 & 1539 \\
\hline 1561.3 & 1561.8 & $S$ & \begin{tabular}{|l|} 
LASL, G-9, O.R. Vine \\
$6 / 20 / 80$
\end{tabular} & G4 & 6,7 & 7,9 & 1561 \\
\hline 1639.4 & 1640.3 & $\mathrm{~s}$ & $\begin{array}{l}\text { LASL, G-9, O.R. } \\
6 / 20 / 80, \text { Vine } \\
\end{array}$ & G4 & 6,7 & 7 & 1639 \\
\hline Note 11 & & & & G4 & 7 & 7,9 & 1693 \\
\hline Note 11 & & & & G4 & 7 & 7,9 & 1748 \\
\hline 1774.2 & 1775.0 & $S$ & $\begin{array}{l}\text { LASL G-9, O.R. Vine, } \\
6 / 20 / 80\end{array}$ & G4 & 6,7 & 7,9 & 1774 \\
\hline Note 11 & & & & $\mathrm{G} 4$ & 7 & 7,9 & 1784 \\
\hline Note 11 & & & & G4 & 7 & 7,9 & 1799 \\
\hline 1819.6 & 1820.2 & $\mathrm{~S}$ & $\begin{array}{l}\text { LASL, G-9, O.R. Vine, } \\
6 / 20 / 80\end{array}$ & G4 & 6,7 & 7,9 & 1819 \\
\hline 1941.0 & 1942.0 & $S$ & $\begin{array}{l}\text { LANL, Lawrence, No } \\
\text { O.R. }\end{array}$ & G4 & 7 & 7,9 & 1942 \\
\hline 2136.2 & 2136.3 & s & $\begin{array}{l}\text { LASL G-9, Vine, O.R. } \\
6 / 20 / 80\end{array}$ & G4 & 6,7 & 7,9 & 2136 \\
\hline Note 11 & & & & G4 & 7 & 7,9 & 2173 \\
\hline 2190.8 & 2190.9 & $S$ & $\begin{array}{l}\text { LASL, O.R. Smyth, } \\
11 / 16 / 81\end{array}$ & G4,6 & 6,7 & 7 & 2190 \\
\hline 2198.5 & 2198.6 & $S$ & $\begin{array}{l}\text { LASL G-9, O.R. Vine, } \\
6 / 20 / 80\end{array}$ & G4 & 6,7 & 7,9 & 2198 \\
\hline 2256.2 & & $\mathrm{~s}$ & $\begin{array}{l}\text { LASL, O.R. Smyth, } \\
\text { 4/6/81 }\end{array}$ & $\mathrm{G} 4,6$ & 6,7 & 7,10 & 2256 \\
\hline Note 11 & & & & G4 & & 10 & 2279 \\
\hline Note 11 & & & & G4 & 7 & 7,10 & 2290 \\
\hline 2316.0 & & $S$ & $\begin{array}{l}\text { LASL, G-9, block out of } \\
\text { place }\end{array}$ & G4 & 7 & 7,9 & 2316 \\
\hline 2401.0 & 2401.2 & s & $\begin{array}{l}\text { LASL G-9, O.R., Smyth, } \\
\text { 4/6/81, Incomplete } \\
\text { marking }\end{array}$ & $\mathrm{G} 4,6$ & 6,7 & 7 & 2401 \\
\hline 2555.3 & 2555.8 & $S$ & $\begin{array}{l}\text { LASL G-9, Vine, O.R., } \\
6 / 20 / 80\end{array}$ & G4 & 6,7 & 7,10 & 2456 \\
\hline 2486.7 & 2487.2 & $S$ & $\begin{array}{l}\text { LASL G-9, O.R. Vine, } \\
6 / 20 / 80\end{array}$ & G4 & 6,7 & 7,10 & 2486 \\
\hline 2499.3 & 2499.5 & $S$ & $\begin{array}{l}\text { LASL G-9, O.R. Smythe, } \\
4 / 6 / 81\end{array}$ & $\mathrm{G} 4,6$ & 6,7 & 7,10 & 2499 \\
\hline 2506.3 & 2506.4 & $S$ & $\begin{array}{l}\text { LASL G-9, O.R. Smythe, } \\
4 / 6 / 81\end{array}$ & $\mathrm{G} 4,6$ & $6,7,8$ & 7,10 & 2506 \\
\hline
\end{tabular}


Table 6b. Detailed Mapping of Samples from Collection to Analysis for USW G-1 (Continued)

\begin{tabular}{|c|c|c|c|c|c|c|c|}
\hline $\begin{array}{l}\text { Sample } \\
\text { From } \\
\text { (ft) })^{1}\end{array}$ & $\begin{array}{l}\text { Sample } \\
\text { To }(\mathrm{ft})^{1}\end{array}$ & $\begin{array}{c}\text { Sample } \\
\text { Designator }\end{array}$ & $\begin{array}{l}\text { Sample Management } \\
\text { Facility Records }{ }^{1}\end{array}$ & $\begin{array}{c}\text { Reference for } \\
\text { Sample Visual } \\
\text { Description }\end{array}$ & $\begin{array}{c}\text { Reference } \\
\text { for Notation } \\
\text { of Sample } \\
\text { Transmittal } \\
\text { / Receipt }\end{array}$ & $\begin{array}{c}\text { Reference } \\
\text { for Notation } \\
\text { for XRD or } \\
\text { Thin } \\
\text { Section } \\
\end{array}$ & $\begin{array}{c}\text { DTN } \\
\text { Sample } \\
\text { Depth (ft) } \\
\text { for XRD } \\
\text { Analyses at } \\
\text { LANL }^{3}\end{array}$ \\
\hline 2544.6 & 2544.7 & $S$ & $\begin{array}{l}\text { LASL, G-9, Smyth, O.R., } \\
4 / 6 / 81\end{array}$ & $\mathrm{G} 4,6$ & 6,7 & 7,10 & 2544 \\
\hline 2564.4 & 2564.8 & $S$ & LANL, Carlos 10/24/85 & G4 & $6,7,8$ & 10 & 2564 \\
\hline 2600.5 & 2600.6 & $S$ & $\begin{array}{l}\text { LASL G-9, O.R., Vine, } \\
6 / 20 / 80\end{array}$ & G4 & 6,7 & $7,9,10$ & 2600 \\
\hline 2606.1 & 2606.2 & S & $\begin{array}{l}\text { LASL G-9, O.R., Smyth, } \\
11 / 6 / 81\end{array}$ & $\mathrm{G} 4,6$ & 6,7 & 7,10 & 2606 \\
\hline 2609.9 & 2610.5 & $S$ & LASL, Can & G4 & 7 & $7,9,10$ & 2607 \\
\hline 2622.0 & & $s$ & $\begin{array}{l}\text { LASL G-9, O.R. Smyth, } \\
4 / 6 / 81\end{array}$ & $\mathrm{G} 4,6$ & 6,7 & $7,9,10$ & 2622 \\
\hline 2641.1 & 2641.6 & $s$ & $\begin{array}{l}\text { LASL G-9, Vine O.R. } \\
6 / 20 / 80\end{array}$ & G4 & 6,7 & $7,9,10$ & 2641 \\
\hline 2663.8 & 2663.9 & S & $\begin{array}{l}\text { LASL G-9, Smyth, O.R., } \\
4 / 6 / 81\end{array}$ & $\mathrm{G} 4,6$ & 6,7 & 7,10 & 2663 \\
\hline 2734.2 & 2734.3 & $S$ & LASL G-9, Smyth, 4/6/81 & $\mathrm{G} 4,6$ & 6,7 & 710 & 2734 \\
\hline 2765.9 & 2766.0 & $S$ & LASL G-9, O.R., 5/27/80 & $\mathrm{G} 4,6$ & 6,7 & 7,10 & 2765 \\
\hline 2804.0 & 2805.0 & $\mathrm{~S}$ & $\begin{array}{l}\text { LASL G-9, CNC, O.R., } \\
\text { Smyth, 9/24/80 }\end{array}$ & $\mathrm{G} 4,6$ & 6 & 10 & 2804 \\
\hline 2805.0 & 2805.1 & $S$ & $\begin{array}{l}\text { LASL G-9, CNC, O.R., } \\
\text { Smyth, 4/6/81 }\end{array}$ & $\mathrm{G} 4,6$ & 6,7 & 7,10 & 2805 \\
\hline 2820.1 & 2820.2 & $S$ & $\begin{array}{l}\text { LASL G-9, Smyth, O.R., } \\
4 / 6 / 81\end{array}$ & $\mathrm{G} 4,6$ & 6,7 & 10 & 2820 \\
\hline 2838.0 & 2838.1 & $S$ & $\begin{array}{l}\text { LASL G-9, Smyth, O.R., } \\
4 / 6 / 81\end{array}$ & $\mathrm{G} 4,6$ & 6,7 & 7,10 & 2838 \\
\hline 2868.3 & 2869.0 & $S$ & $\begin{array}{l}\text { LASL G-9, Vine, 6/20/80, } \\
\text { O.R. shows } 2869.0\end{array}$ & G4 & 6,7 & 7,10 & 2868 \\
\hline 2884.8 & 2884.9 & $S$ & LASL G-9 & $\mathrm{G} 4,6$ & 6,7 & 10 & 2884 \\
\hline 2915.8 & 2915.9 & $S$ & LASL G-9, O.R., 4/6/81 & $\mathrm{G} 4,6$ & 6,7 & 7,10 & 2915 \\
\hline 2932.5 & 2932.6 & $s$ & O.R., $4 / 6 / 81$ & $\mathrm{G} 4,6$ & 6,7 & 10 & 2932 \\
\hline 2937.0 & 2937.2 & $S$ & O.R., $10 / 24 / 85$ & $\mathrm{G} 4,6$ & 6,8 & 10 & 2937 \\
\hline 2948.0 & 2948.1 & $S$ & $\begin{array}{l}\text { LASL G-9, O.R., 4/6/81, } \\
\text { incomplete marking }\end{array}$ & $\mathrm{G} 4,6$ & 6,7 & 7,10 & 2948 \\
\hline Note 11 & & & & G4 & 7 & $7,9,10$ & 2966 \\
\hline 2981.6 & 2981.7 & S & $\begin{array}{l}\text { LASL G-9, O.R., 4/6/81, } \\
\text { Smyth }\end{array}$ & $\mathrm{G} 4,6$ & 6,7 & 10 & 2981 \\
\hline 3018.3 & 3018.4 & $S$ & $\begin{array}{l}\text { LASL G-9, O.R., Smyth, } \\
4 / 6 / 81\end{array}$ & $\mathrm{G} 4,6$ & 6,7 & 7,10 & 3018 \\
\hline 3079.0 & 3079.2 & $s$ & $\begin{array}{l}\text { LASL G-9, J.R Smith } \\
4 / 6 / 81 \text { OR }\end{array}$ & $\mathrm{G} 4,6$ & 6,7 & 7,10 & 3079 \\
\hline 3167.0 & 3167.1 & $s$ & LASL G-9 NR & $\mathrm{G} 4,6$ & 6,7 & 7,10 & 3167 \\
\hline 3288.5 & 3288.6 & s & $\begin{array}{l}\text { LASL G-9, Smyth } 4 / 6 / 81 \\
\text { OR }\end{array}$ & $\mathrm{G} 4,6$ & 6,7 & 7,10 & 3288 \\
\hline
\end{tabular}


Table 6b. Detailed Mapping of Samples from Collection to Analysis for USW G-1 (Continued)

\begin{tabular}{|c|c|c|c|c|c|c|c|}
\hline $\begin{array}{l}\text { Sample } \\
\text { From } \\
\text { (ft) }{ }^{1}\end{array}$ & $\begin{array}{l}\text { Sample } \\
\text { To (ft) }\end{array}$ & $\begin{array}{c}\text { Sample } \\
\text { Designator }\end{array}$ & $\begin{array}{l}\text { Sample Management } \\
\text { Facility Records }{ }^{1}\end{array}$ & $\begin{array}{c}\text { Reference for } \\
\text { Sample Visual } \\
\text { Description }\end{array}$ & $\begin{array}{c}\text { Reference } \\
\text { for Notation } \\
\text { of Sample } \\
\text { Transmittal } \\
\text { / Receipt }\end{array}$ & $\begin{array}{c}\text { Reference } \\
\text { for Notation } \\
\text { for XRD or } \\
\text { Thin } \\
\text { Section } \\
\end{array}$ & $\begin{array}{c}\text { DTN } \\
\text { Sample } \\
\text { Depth (ft) } \\
\text { for XRD } \\
\text { Analyses at } \\
\text { LANL }^{3} \\
\end{array}$ \\
\hline 3401.1 & 3401.4 & $S$ & $\begin{array}{l}\text { LASL G-9, } 6 \text { april 81, } \\
\text { Smyth OR }\end{array}$ & $\mathrm{G} 4,6$ & 6,7 & 7,10 & 3401 \\
\hline 3523.6 & 3523.9 & $s$ & $\begin{array}{l}\text { LASL G-9, Smyth 4/6/81 } \\
\text { OR }\end{array}$ & $\mathrm{G} 4,6$ & 6,7 & 7,10 & 3523 \\
\hline 3621.2 & 3621.5 & $\mathrm{~s}$ & LASL G-9 & G4 & 6,7 & $7,9,10$ & 3621 \\
\hline 3810.5 & 3810.9 & $S$ & LASL G9, OR 8/15/80 & G4 & 6 & 10 & 3810 \\
\hline 3940.5 & 3941.1 & $\mathrm{~s}$ & LASL G9, OR 8/15/80 & G4 & 6,7 & 7,10 & 3940 \\
\hline 4246.7 & & S & $\begin{array}{l}\text { LASL G-9, X-Ray, Smyth } \\
\text { OR } 8 / 15 / 80^{\circ}\end{array}$ & G4 & 6 & 10 & 4246 \\
\hline 4400.3 & 4400.9 & $S$ & $\begin{array}{l}\text { LASL G9, Smyth OR } \\
8 / 15 / 80\end{array}$ & G4 & 6,7 & 10 & 4400 \\
\hline 4503.8 & 4504.4 & $S$ & $\begin{array}{l}\text { LASL G9 - O.R. Smyth } \\
8 / 15 / 80\end{array}$ & G4 & 6,7 & 7,10 & 4503 \\
\hline 4550.0 & 4551.0 & $s$ & NR & G4 & & 10 & 4555 \\
\hline 4612.0 & 4612.8 & $S$ & $\begin{array}{l}\text { LASL, G9, O.R., 8/15/80, } \\
\text { 1" Plug }\end{array}$ & G4 & 6,7 & 7,10 & 4612 \\
\hline Note 11 & & & & G4 & & 10 & 4626 \\
\hline 4652.9 & & $S$ & $\begin{array}{l}\text { LASL, G-9, x-ray, } \\
8 / 15 / 80, \text { smyth }\end{array}$ & G4 & 6 & 10 & 4652 \\
\hline 4700.1 & 4701.0 & $s$ & LASL, G9, O.R., 8/15/80 & G4 & 6,7 & 7,10 & 4700 \\
\hline 4750.5 & 4750.7 & $S$ & $\begin{array}{l}\text { LASL,G9, X-RAY, T.S., } \\
\text { O.R., } 8 / 15 / 80\end{array}$ & G4 & 6 & 10 & 4750 \\
\hline 4805.0 & 4805.7 & $S$ & $\begin{array}{l}\text { LASL, G9, O.R., reads } \\
4805.1 \text { for last, } 8 / 15 / 80\end{array}$ & G4 & 6,7 & 7,10 & 4805 \\
\hline 4848.0 & 4848.1 & $\mathrm{~s}$ & LASL,G-9, O.R., 8/15/80 & G4 & 6 & 10 & 4848 \\
\hline 4876.5 & 4877.3 & $\mathrm{~s}$ & LASL G-9, 8/15/80 & G4 & 6,7 & 7,10 & 4876 \\
\hline 4912.7 & 4913.3 & $S$ & $\begin{array}{l}\text { LASL G9, O.R. 8/15/80 } \\
\text { Smyth }\end{array}$ & G4 & 6,7 & 10 & 4912 \\
\hline 4941.6 & 4941.7 & $S$ & $\begin{array}{l}\text { LASL G9 XRAY, O.R. } \\
\text { 8/15/80 Smyth }\end{array}$ & G4 & 6 & 10 & 4941 \\
\hline 4997.6 & 4998.2 & $S$ & LASL G-9, O.R. 8/15/80 & G4 & 6,7 & 7,10 & 4998 \\
\hline 5026.4 & 5026.6 & $S$ & $\begin{array}{l}\text { LASL G9 - X-ray, O.R. } \\
8 / 15 / 80 \text { Smyth } 5026 \text { - } \\
5026.6\end{array}$ & G4 & 6,7 & 7,10 & 5026 \\
\hline 5049.4 & & $S$ & $\begin{array}{l}\text { LASL G9, X-ray, O.R. } \\
\text { 8/15/80 Smyth }\end{array}$ & G4 & 6 & 10 & 5049 \\
\hline 5093.8 & 5094.5 & $s$ & LASL, G9, OR 8/15/80 & G4 & 6,7 & 10 & 5093 \\
\hline 5126.8 & 5127.3 & $\mathrm{~s}$ & LASL G-9, 5/18/80 OR & G4 & 6,7 & 7,10 & 5126 \\
\hline 5167.4 & 5167.6 & S & $\begin{array}{l}\text { LASL G9, X-ray, OR } \\
8 / 15 / 80 \text { Smyth }\end{array}$ & G4 & 6,7 & 7,10 & 5167 \\
\hline 5212.8 & 5213.6 & S & LASL G-9, OR 8/15/80 & G4 & 6,7 & 10 & 5212 \\
\hline 5252.1 & 5253.1 & $s$ & LANL OR NR & G4 & 6 & 10 & 5253 \\
\hline
\end{tabular}


Table 6b. Detailed Mapping of Samples from Collection to Analysis for USW G-1 (Continued)

\begin{tabular}{|c|c|c|c|c|c|c|c|}
\hline $\begin{array}{l}\text { Sample } \\
\text { From } \\
\text { (ft) }\end{array}$ & $\begin{array}{l}\text { Sample } \\
\text { To }(\mathrm{ft})^{1}\end{array}$ & $\begin{array}{c}\text { Sample } \\
\text { Designator }\end{array}$ & $\begin{array}{l}\text { Sample Management } \\
\text { Facility Records' }^{\prime}\end{array}$ & $\begin{array}{c}\text { Reference for } \\
\text { Sample Visual } \\
\text { Description }\end{array}$ & $\begin{array}{c}\text { Reference } \\
\text { for Notation } \\
\text { of Sample } \\
\text { Transmittal } \\
\text { / Receipt }\end{array}$ & \begin{tabular}{|c|} 
Reference \\
for Notation \\
for XRD or \\
Thin \\
Section \\
\end{tabular} & $\begin{array}{c}\text { DTN } \\
\text { Sample } \\
\text { Depth (ft) } \\
\text { for XRD } \\
\begin{array}{c}\text { Analyses at } \\
\text { LANL }^{3}\end{array} \\
\end{array}$ \\
\hline 5296.2 & 5296.9 & $S$ & LANL G-9, no OR & G4 & 6,7 & 10 & 5296 \\
\hline 5310.1 & 5310.2 & $S$ & $\begin{array}{l}\text { LASL G9 X-ray, O.R., } \\
\text { Smyth, } 8 / 15 / 80\end{array}$ & G4 & 6 & 10 & 5310 \\
\hline 5311.9 & 5312.6 & S & $\begin{array}{l}\text { LASL G9, O.R., Smyth, } \\
8 / 15 / 80\end{array}$ & G4 & 6 & 10 & 5311 \\
\hline 5329.9 & 5330.0 & S & $\begin{array}{l}\text { LASL G9 X-ray, O.R., } \\
8 / 15 / 80\end{array}$ & G4 & 6 & 10 & 5329 \\
\hline 5338.7 & & $S$ & $\begin{array}{l}\text { LASL G9, X-ray, O.R., } \\
8 / 15 / 80 \text {, stacked }\end{array}$ & G4 & 6 & 10 & 5338 \\
\hline 5348.5 & 5348.8 & $S$ & $\begin{array}{l}\text { LASL G9, X-ray, O.R, } \\
\text { Stacked, } 8 / 15 / 80\end{array}$ & G4 & 6,7 & 7,10 & 5348 \\
\hline 5378.0 & & S & $\begin{array}{l}\text { LASL G9, X-ray, O.R., } \\
8 / 15 / 80 \text {, Stacked }\end{array}$ & G4 & 6 & 10 & 5378 \\
\hline 5412.9 & 5413.4 & S & $\begin{array}{l}\text { LASL G9, O.R., Smyth, } \\
8 / 15 / 80\end{array}$ & G4 & 6,7 & $\begin{array}{l}7,10 \\
?\end{array}$ & 5412 \\
\hline 5433.1 & & S & $\begin{array}{l}\text { LASL G9, X-ray, O.R., } \\
\text { Smyth, 8/18/80 }\end{array}$ & G4 & 6 & 10 & 5433 \\
\hline 5458.4 & 5458.5 & $S$ & $\begin{array}{l}\text { LASL G4 X-ray, O.R. } \\
8 / 15 / 80\end{array}$ & G4 & 6 & 10 & 5458 \\
\hline 5477.4 & & $S$ & $\begin{array}{l}\text { LASL G9 X-ray, O.R. 8- } \\
15-80\end{array}$ & G4 & 6 & 10 & 5477 \\
\hline 5498.7 & 5499.5 & S & $\begin{array}{l}\text { LASL G-9, 8/15/80 O.R. } \\
\text { Smyth }\end{array}$ & G4 & 6,7 & 10 & 5498 \\
\hline 5534.2 & & $S$ & $\begin{array}{l}\text { LASL G-9, X-ray chip, } \\
\text { O.R. show second } \\
\text { measurement } 5534.3 \\
8 / 15 / 80 \text {, stacked, smyth }\end{array}$ & G4 & 6 & 10 & 5534 \\
\hline 5560.0 & & $S$ & $\begin{array}{l}\text { LASL G9 X-ray, O.R. } \\
8 / 15 / 80\end{array}$ & G4 & 6 & 10 & 5560 \\
\hline 5596.4 & 5596.5 & $S$ & $\begin{array}{l}\text { LASL G-9, O.R. Lists } \\
\text { only } 5596.4,8 / 15 / 80 \\
\text { Smyth }\end{array}$ & G4 & 6 & 10 & 5596 \\
\hline 5637.1 & 5637.9 & $S$ & $\begin{array}{l}\text { LASL G-9, 8/15/80 } \\
\text { Smyth }\end{array}$ & G4 & 6,7 & 10 & 5637 \\
\hline 5679.4 & 5680.1 & $S$ & LASL G9 - 8/15/80 & G4 & 6,7 & 10 & 5679 \\
\hline 5699.0 & & $S$ & N.R. & G4 & & 10 & 5699 \\
\hline 5746.4 & 5747.2 & $S$ & LASL G9, O.R. $8 / 15 / 80$ & G4 & 6,7 & 7,10 & 5746 \\
\hline 5803.0 & & $s$ & $\begin{array}{l}\text { LASL, G-9 X-ray } \\
\text { Incomplete }\end{array}$ & G4 & 6 & 10 & 5803 \\
\hline 5847.3 & 5848.2 & $S$ & LASL G-9, O.R. 8-15-80 & G4 & 6,7 & 10 & 5847 \\
\hline
\end{tabular}


Table 6b. Detailed Mapping of Samples from Collection to Analysis for USW G-1 (Continued)

\begin{tabular}{|c|c|c|c|c|c|c|c|}
\hline $\begin{array}{c}\text { Sample } \\
\text { From } \\
\text { (ft) }^{1}\end{array}$ & $\begin{array}{c}\text { Sample } \\
\text { To (ft) }^{1}\end{array}$ & $\begin{array}{c}\text { Sample } \\
\text { Designator }^{1,2}\end{array}$ & $\begin{array}{c}\text { Sample Management } \\
\text { Facility Records }\end{array}$ & $\begin{array}{c}\text { Reference for } \\
\text { Sample Visual } \\
\text { Description }\end{array}$ & $\begin{array}{c}\text { Reference } \\
\text { for Notation } \\
\text { of Sample } \\
\text { Transmittal } \\
\text { / Receipt }\end{array}$ & $\begin{array}{c}\text { Reference } \\
\text { for Notation } \\
\text { for XRD or } \\
\text { Thin } \\
\text { Section }\end{array}$ & $\begin{array}{c}\text { DTN } \\
\text { Sample } \\
\text { Depth (ft) } \\
\text { for XRD } \\
\text { Analyses at } \\
\text { LANL }^{3}\end{array}$ \\
\hline 5898.7 & 5898.8 & S & $\begin{array}{c}\text { X-ray chip, Smyth 8-15- } \\
80, \text { O.R. 1898.8 }\end{array}$ & G4 & 6 & 10 & 5898 \\
\hline 5947.4 & 5948.2 & S & LASL G-9, O.R. 8-15-80 & G4 & 6,7 & 10 & 5947 \\
\hline 5980.0 & 5980.0 & S & LASL G-9 X-ray, 598..00 & G4 & 6 & 10 & 5980 \\
\hline
\end{tabular}

NOTES: ${ }^{1}$ From SMF (Finnegan 2001).

Standard whole round core (S).

DTN LADB831321AN98.002 SEP Table S98163_013.

${ }^{64}$ Report by Bish et al. 1981. LA-8840-MS; General description, not sample specific.

${ }^{65}$ Report by Carrol et al. 1981. LA-9000-MS; General description, not sample specific.

6 Information obtained by Ayres and Bonisolli (2001).

7 LANL Scientific Notebook TWS-G-9-7/80-7, Pages 32, 33, 80, 148 (Caporuscio 2001b).

8 LANL Scientific Notebook TWS-G-9-6/81-9, Pages 139, 143 (Caporuscio 2001a).

9 LANL Scientific Notebook TWS-G-9-3/80-17, Pages 93, 94, 96, 97, 100 (Sykes 2001b).

10 LANL Scientific Notebook TWS-ESS-1-9/85-10 (Chipera 1985). Page numbers not identified on record Copy.

11 No record for this LANL sample in the core box. 
Table 6c. Detail Mapping of Samples from Collection to Analysis for USW GU-3

\begin{tabular}{|c|c|c|c|c|c|c|c|}
\hline $\begin{array}{l}\text { Sample } \\
\text { From } \\
(\mathrm{ft})^{1}\end{array}$ & $\begin{array}{l}\text { Sample } \\
\text { To }(\mathrm{ft})^{1}\end{array}$ & $\begin{array}{c}\text { Sample } \\
\text { Designator }\end{array}$ & $\begin{array}{l}\text { Sample Management } \\
\text { Facility Records's }\end{array}$ & \begin{tabular}{|c|} 
Reference for \\
Sample Visual \\
Description
\end{tabular} & $\begin{array}{c}\text { Reference } \\
\text { for Notation } \\
\text { of Sample } \\
\text { Transmittal } \\
\text { / Receipt }\end{array}$ & $\begin{array}{c}\text { Reference } \\
\text { for Notation } \\
\text { of XRD or } \\
\text { Thin } \\
\text { Section }\end{array}$ & $\begin{array}{c}\text { DTN } \\
\text { Sample } \\
\text { Depth (ft) } \\
\text { for XRD } \\
\text { Analyses at } \\
\text { LANL }^{3}\end{array}$ \\
\hline 31.0 & 31.1 & $s$ & $\begin{array}{l}\text { USGS, chem sample, } \\
\text { OR } 5 / 18 / 83 \text {, block is }\end{array}$ & 4 & 6 & & 31.0 \\
\hline Note 7 & & & $\begin{array}{l}\text { two thin sections taken, } \\
\text { block missing }\end{array}$ & 4 & 6 & & 45.0 \\
\hline Note 7 & & & $\begin{array}{l}\text { LANL+ USGS t.s. } \\
\text { encore block missing }\end{array}$ & 4 & 6 & & 79.0 \\
\hline 103 & 103.2 & $s$ & $\begin{array}{l}\text { LANL, OR } 5 / 7 / 82 \text {, Dave } \\
\text { Vaniman }\end{array}$ & 4 & 6 & & 103.1 \\
\hline 103 & 103.2 & $S$ & $\begin{array}{l}\text { LANL, OR } 5 / 7 / 82 \text {, Dave } \\
\text { Vaniman }\end{array}$ & 4 & 6 & & $\begin{array}{c}103- \\
\text { Fracture }\end{array}$ \\
\hline 196 & 196.5 & $s$ & $\begin{array}{l}\text { LANL, OR } 5 / 7 / 82 \text {, Dave } \\
\text { Vaniman }\end{array}$ & 4 & 6 & & 196.3 \\
\hline 196 & 196.5 & $S$ & $\begin{array}{l}\text { LANL, OR } 5 / 7 / 82 \text {, Dave } \\
\text { Vaniman }\end{array}$ & 4 & 6 & & 196-Vein \\
\hline Note 7 & & & $\begin{array}{l}\text { USGS-LANL t.t, block } \\
\text { missing, OR USGS thin } \\
\text { sect.4/16/82, B.Scott, } \\
\text { OR LANL on 5/7/82, } \\
\text { D.Vaniman } \\
\end{array}$ & 4 & 6 & & 245.7 \\
\hline Note 7 & & & $\begin{array}{l}\text { USGS-t.s.-LANL, OR } \\
\text { USGS 5/2/82 B. Scott } \\
\text { OR LANL 5/7/82 D. } \\
\text { Vaniman } \\
\end{array}$ & 4 & 6 & & 303.6 \\
\hline 316.7 & 316.9 & $s$ & LANL, OR $5 / 7 / 82$ & 4 & 6 & & 316.8 \\
\hline Note 7 & & & $\begin{array}{l}\text { USGS thin section } \\
\text { block missing, OR } \\
\text { LANL-D.Vaniman } \\
5 / 7 / 82 \text {, USGS-B.Scott } \\
\text { 5/2/82 1" plug } \\
\end{array}$ & 4 & 6 & & 341.5 \\
\hline 355.9 & 356 & $S$ & $\begin{array}{l}\text { USGS-chem, Or reads } \\
355.9-356.1,5 / 18 / 83 \\
\text { t.s. LANL + USGS, } \\
\text { block missing, LANL } \\
5 / 7 / 82 \text { D Vanimqn, } \\
\text { USGS 5/18/83, Bob } \\
\text { Denver } \\
\end{array}$ & 4 & 6 & & 356.5 \\
\hline Note 7 & & & $\begin{array}{l}\text { t.s. LANL, Block is } \\
\text { missing Dave } \\
\text { Vamiman,LANL OR } \\
5 / 7 / 82\end{array}$ & 4 & 6 & & 376.1 \\
\hline 409.8 & 410.2 & $S$ & LANL OR $5 / 7 / 82$ & 4 & 6 & & 410.0 \\
\hline Note 8 & & & & 4 & 6 & & 414.3 \\
\hline Note 8 & & & & 4 & 6 & & 417.5 \\
\hline Note 8 & & & & 4 & 6 & & 424.4 \\
\hline Note 8 & & & & 4 & 6 & & 429.0 \\
\hline Note 8 & & & & 4 & 6 & & 429-Vein \\
\hline Note 8 & & & & 4 & 6 & & 430.5 \\
\hline
\end{tabular}


Table 6c. Detail Mapping of Samples from Collection to Analysis for USW GU-3 (Continued)

\begin{tabular}{|c|c|c|c|c|c|c|c|}
\hline $\begin{array}{l}\text { Sample } \\
\text { From } \\
(\mathrm{ft})^{1}\end{array}$ & $\begin{array}{l}\text { Sample } \\
\text { To (ft) }{ }^{1}\end{array}$ & $\begin{array}{c}\text { Sample } \\
\text { Designator }\end{array}$ & $\begin{array}{l}\text { Sample Management } \\
\text { Facility Records }^{1}\end{array}$ & $\begin{array}{c}\text { Reference for } \\
\text { Sample Visual } \\
\text { Description }\end{array}$ & $\begin{array}{c}\text { Reference } \\
\text { for Notation } \\
\text { of Sample } \\
\text { Transmittal } \\
\text { / Receipt }\end{array}$ & $\begin{array}{c}\text { Reference } \\
\text { for Notation } \\
\text { of XRD or } \\
\text { Thin } \\
\text { Section }\end{array}$ & $\begin{array}{c}\text { DTN } \\
\text { Sample } \\
\text { Depth (ft) } \\
\text { for XRD } \\
\text { Analyses at }^{3} \text { LANL }^{3}\end{array}$ \\
\hline Note 8 & & & & 4 & 6 & & 465.5 \\
\hline 481.8 & 482.2 & $S$ & & 4 & 6 & & 482.0 \\
\hline 519.8 & 520.2 & $w$ & & 4 & 6 & & 520.3 \\
\hline 519.8 & 520.2 & $w$ & & 4 & 6 & & 520-Cavity \\
\hline 525.0 & 525.35 & $\mathrm{~S}$ & & 4 & 6 & & 525.3 \\
\hline 527.8 & 529.1 & $w$ & & 4 & 6 & & 525-Cavity \\
\hline 578.8 & 579.1 & $\mathrm{~S}$ & $\begin{array}{l}\text { Dave Vaniman LANL, } \\
\text { OR } 5 / 7 / 82\end{array}$ & 4 & 6 & & 579.0 \\
\hline Note 7 & & & $\begin{array}{l}\text { T.S. block missing, } \\
\text { D.Vaniman LANL } \\
5 / 7 / 82\end{array}$ & 4 & 6 & & 633.4 \\
\hline 674.6 & 674.8 & $\mathrm{~S}$ & $\begin{array}{l}\text { D.Vaniman LANL OR } \\
5 / 7 / 82\end{array}$ & 4 & 6 & & 674.7 \\
\hline 674.6 & 674.8 & $\mathrm{~S}$ & $\begin{array}{l}\text { D.Vaniman LANL OR } \\
5 / 7 / 82\end{array}$ & 4 & 6 & & $\begin{array}{c}674- \\
\text { Fracture } \\
\end{array}$ \\
\hline 702.45 & 702.65 & $S$ & $\begin{array}{l}\text { D.Vaniman LANL OR } \\
5 / 7 / 82\end{array}$ & 4 & 6 & & 702.5 \\
\hline Note 7 & & & $\begin{array}{l}\text { D.Vaniman LANL OR } \\
5 / 7 / 82\end{array}$ & 4 & 6 & & 769.1 \\
\hline 849.35 & 849.5 & $S$ & $\begin{array}{l}\text { D.Vaniman LANL OR } \\
5 / 7 / 82\end{array}$ & 4 & 6 & & 849.4 \\
\hline 849.35 & 849.5 & $\mathrm{~S}$ & $\begin{array}{l}\text { D.Vaniman LANL OR } \\
5 / 7 / 82\end{array}$ & 4 & 6 & & $\begin{array}{c}\text { 849- } \\
\text { Fracture }\end{array}$ \\
\hline 910.4 & 910.7 & $S$ & $\begin{array}{l}\text { D.Vaniman LANL OR } \\
5 / 7 / 82\end{array}$ & 4 & 6 & & 910.5 \\
\hline 910.4 & 910.7 & $S$ & $\begin{array}{l}\text { D.Vaniman LANL OR } \\
5 / 7 / 82\end{array}$ & 4 & 6 & & $\begin{array}{c}910- \\
\text { Fracture }\end{array}$ \\
\hline 924.1 & 924.5 & $S$ & $\begin{array}{l}\text { D.Vaniman LANL OR } \\
5 / 7 / 82\end{array}$ & 4 & 6 & & 924.3 \\
\hline 924.1 & 924.5 & $S$ & $\begin{array}{l}\text { D.Vaniman LANL OR } \\
5 / 7 / 82\end{array}$ & 4 & 6 & & $\begin{array}{c}\text { 924- } \\
\text { Fracture }\end{array}$ \\
\hline 951.0 & 951.3 & $\mathrm{~S}$ & $\begin{array}{l}\text { D. Vaniman LANL OR } \\
5 / 7 / 82\end{array}$ & 4 & 6 & & 951.1 \\
\hline 951.0 & 951.3 & $\mathrm{~S}$ & $\begin{array}{l}\text { D. Vaniman LANL OR } \\
5 / 7 / 82\end{array}$ & 4 & 6 & & $\begin{array}{c}951- \\
\text { Fracture }\end{array}$ \\
\hline 954.75 & 954.95 & $\mathrm{~S}$ & D.Vaniman OR $5 / 7 / 82$ & 4 & 6 & & 954.8 \\
\hline 1026.8 & 1027.1 & $\mathrm{~S}$ & $\begin{array}{l}\text { D.Vaniman LANL OR } \\
5 / 7 / 82\end{array}$ & 4 & 6 & & 1027.0 \\
\hline 1026.8 & 1027.1 & $\mathrm{~S}$ & $\begin{array}{l}\text { D.Vaniman LANL OR } \\
5 / 7 / 82\end{array}$ & 4 & 6 & & $\begin{array}{l}1027- \\
\text { Fracture }\end{array}$ \\
\hline 1060.9 & 1061.1 & $\mathrm{~S}$ & $\begin{array}{l}\text { Day (?) LANL OR } \\
5 / 7 / 82\end{array}$ & 4 & 6 & & 1061.0 \\
\hline Note 7 & & & $\begin{array}{l}\text { 1" plug Dave Vaniman } \\
\text { LANL OR } 5 / 7 / 82\end{array}$ & 4 & 6 & & 1130.3 \\
\hline
\end{tabular}


Table 6c. Detail Mapping of Samples from Collection to Analysis for USW GU-3 (Continued)

\begin{tabular}{|c|c|c|c|c|c|c|c|}
\hline $\begin{array}{l}\text { Sample } \\
\text { From } \\
\text { (ft) })^{1}\end{array}$ & $\begin{array}{l}\text { Sample } \\
\text { To }(\mathrm{ft})^{1}\end{array}$ & $\begin{array}{c}\text { Sample } \\
\text { Designator }\end{array}$ & $\begin{array}{c}\text { Sample Management } \\
\text { Facility Records' }\end{array}$ & $\begin{array}{c}\text { Reference for } \\
\text { Sample Visual } \\
\text { Description }\end{array}$ & $\begin{array}{c}\text { Reference } \\
\text { for Notation } \\
\text { of Sample } \\
\text { Transmittal } \\
\text { / Receipt }\end{array}$ & \begin{tabular}{|c|} 
Reference \\
for Notation \\
of XRD or \\
Thin \\
Section
\end{tabular} & $\begin{array}{c}\text { DTN } \\
\text { Sample } \\
\text { Depth (ft) } \\
\text { for XRD } \\
\text { Analyses at } \\
\text { LANL }^{3}\end{array}$ \\
\hline 1174.3 & 1175.0 & $S$ & $\begin{array}{l}\text { D.Vaniman LANL OR } \\
5 / 7 / 82\end{array}$ & 4 & 6 & & 1175.0 \\
\hline Note 7 & & & $\begin{array}{l}\text { D.Vaniman LANL OR } \\
5 / 7 / 82 \text {, stacked }\end{array}$ & 4 & 6 & & 1195.7 \\
\hline Note 7 & & & $\begin{array}{l}\text { D.Vaniman LANL OR } \\
5 / 7 / 82, \text { stacked }\end{array}$ & 4 & 6 & & 1195-Vein \\
\hline 1227.15 & 1227.25 & $S$ & LANL OR $5 / 7 / 82$ & 4 & 6 & & 1227.0 \\
\hline 1302.3 & 1302.6 & & $\begin{array}{l}\text { D.Vaniman LANL OR } \\
5 / 7 / 82\end{array}$ & 4 & 6 & & 1302.4 \\
\hline 1321.7 & 1322.0 & s & $\begin{array}{l}\text { D.Vaniman LANL OR } \\
5 / 7 / 82\end{array}$ & 4 & & & 1322.0 \\
\hline Note 8 & & & & 4 & & & 1344.8 \\
\hline Note 8 & & & & 4 & & & 1369.6 \\
\hline 1394.4 & 1394.7 & S & $\begin{array}{l}\text { Vaniman LANL OR } \\
5 / 7 / 82\end{array}$ & 4 & & & 1394.5 \\
\hline 1394.4 & 1394.7 & $S$ & $\begin{array}{l}\text { Vaniman LANL OR } \\
5 / 7 / 82\end{array}$ & 4 & & & 1394.6 \\
\hline Note 8 & & & & 4 & & & 1415.5 \\
\hline Note 7 & & & $\begin{array}{l}\text { LANL OR NR t.s. } \\
\text { block missing }\end{array}$ & 4 & & & 1439.2 \\
\hline 1439.4 & 1439.6 & s & $\begin{array}{l}\text { D.Vaniman Sandia OR } \\
5 / 7 / 82\end{array}$ & 4 & & & 1439.5 \\
\hline Note 8 & & & & 4 & & & 1468.5 \\
\hline Note 8 & & & & 4 & & & 1493.7 \\
\hline Note 7 & & & $\begin{array}{l}\text { D.Vaniman LANL OR } \\
5 / 7 / 82\end{array}$ & 4 & & & 1498.3 \\
\hline Note 8 & & & & 4 & & & 1510.7 \\
\hline 1537.4 & 1537.7 & $S$ & $\begin{array}{l}\text { D.Vaniman LANL OR } \\
5 / 7 / 82\end{array}$ & 4 & & & 1537.5 \\
\hline Note 7 & & & $\begin{array}{l}\text { D.Vaniman LANL OR } \\
5 / 7 / 82\end{array}$ & 4 & & & 1571.6 \\
\hline 1598.6 & 1598.75 & $S$ & $\begin{array}{l}\text { D.Vaniman LANL OR } \\
5 / 7 / 82\end{array}$ & 4 & 6 & & 1598.5 \\
\hline 1602.6 & 1602.8 & & $\begin{array}{l}\text { Bob Scott LANL OR } \\
9 / 24 / 82 \text { chem sample }\end{array}$ & 4 & & & 1603.0 \\
\hline Note 8 & & & & 4 & & & 1624.2 \\
\hline 1653.0 & 1653.5 & $S$ & Vaniman OR $5 / 7 / 82$ & 4 & 6 & & 1653.2 \\
\hline 1708.6 & 1709.3 & $S$ & $\begin{array}{l}\text { D.Vaniman LANL OR } \\
5 / 7 / 82\end{array}$ & 4 & 6 & & 1709.0 \\
\hline Note 8 & & & & 4 & 6 & & 1744.0 \\
\hline Note 8 & & & & 4 & 6 & & $1827.2 \mathrm{c}$ \\
\hline Note 7 & & & $\begin{array}{l}\text { Vaniman LANL OR } \\
5 / 7 / 82 \text {, stacked }\end{array}$ & 4 & 6 & & 1874.0 \\
\hline
\end{tabular}


Table 6c. Detail Mapping of Samples from Collection to Analysis for USW GU-3 (Continued)

\begin{tabular}{|c|c|c|c|c|c|c|c|}
\hline $\begin{array}{l}\text { Sample } \\
\text { From } \\
\text { (ft) }{ }^{1}\end{array}$ & $\begin{array}{l}\text { Sample } \\
\text { To }(\mathrm{ft})^{1}\end{array}$ & $\begin{array}{c}\text { Sample } \\
\text { Designator }\end{array}$ & $\begin{array}{c}\text { Sample Management } \\
\text { Facility Records }^{1}\end{array}$ & $\begin{array}{c}\text { Reference for } \\
\text { Sample Visual } \\
\text { Description }\end{array}$ & $\begin{array}{c}\text { Reference } \\
\text { for Notation } \\
\text { of Sample } \\
\text { Transmittal } \\
\text { I Receipt }\end{array}$ & $\begin{array}{c}\text { Reference } \\
\text { for Notation } \\
\text { of XRD or } \\
\text { Thin } \\
\text { Section }\end{array}$ & $\begin{array}{c}\text { DTN } \\
\text { Sample } \\
\text { Depth (ft) } \\
\text { for XRD } \\
\text { Analyses at } \\
\text { LANL }^{3}\end{array}$ \\
\hline Note 7 & & & 2 pcs, 1" plug & 4 & 6 & & 1935.8 \\
\hline Note 7 & & & $\begin{array}{l}\text { D.Vaniman LANL OR } \\
5 / 7 / 82\end{array}$ & 4 & 6 & & 1986.0 \\
\hline Note 7 & & & $\begin{array}{l}\text { D.Vaniman LANL OR } \\
5 / 7 / 82\end{array}$ & 4 & 6 & & 1993.1 \\
\hline 2013.15 & & & $\begin{array}{l}\text { D.Vaniman LANL OR } \\
5 / 7 / 82\end{array}$ & 4 & 6 & & 2013.2 \\
\hline 2013.15 & & & $\begin{array}{l}\text { D.Vaniman LANL OR } \\
5 / 7 / 82\end{array}$ & 4 & & & $\begin{array}{l}2013- \\
\text { Fracture }\end{array}$ \\
\hline 2070.1 & 2070.2 & $s$ & LANL OR NR & 5 & & & 2070.2 \\
\hline 2138.2 & 2138.3 & $S$ & $\begin{array}{l}\text { D.Vaniman LANL OR } \\
5 / 10 / 82\end{array}$ & 5 & & & 2138.2 \\
\hline 2177.2 & 2177.3 & S & LANL OR $5 / 10 / 82$ & 5 & & & 2177.3 \\
\hline 2189.3 & 2189.4 & $S$ & $\begin{array}{l}\text { D.Vaniman LANL OR } \\
5 / 10 / 82\end{array}$ & 5 & & & 2189.3 \\
\hline Note 8 & & & & 5 & & & 2198.0 \\
\hline Note 8 & & & & 5 & & & Fracture \\
\hline 2227.1 & 2227.7 & $S$ & $\begin{array}{l}\text { R.Rundberg LANL INC } \\
11 \text { OR } 12 / 16 / 82\end{array}$ & 5 & & & 2226.0 \\
\hline 2227.1 & 2227.7 & $s$ & $\begin{array}{l}\text { R.Rundberg LANL INC } \\
11 \text { OR } 12 / 16 / 82 \\
\end{array}$ & 5 & & & Fracture \\
\hline 2359.2 & 2360.1 & 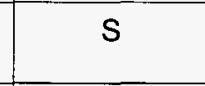 & $\begin{array}{l}\text { R.Rundberg LANL OR } \\
6 / 24 / 82\end{array}$ & 5 & & & 2360.0 \\
\hline 2359.2 & 2360.1 & $\mathrm{~s}$ & $\begin{array}{l}\text { R.Rundberg LANL OR } \\
6 / 24 / 82 \\
\end{array}$ & 5 & & & Fracture \\
\hline 2369.2 & 2369.3 & $s$ & $\begin{array}{l}\text { D.Vaniman LANL OR } \\
5 / 10 / 82\end{array}$ & 5 & & & 2369.4 \\
\hline 2467.2 & 2467.6 & $\mathrm{~s}$ & $\begin{array}{l}\text { LANL, O.R. 5-10-82 } \\
\text { Vaniman }\end{array}$ & 5 & & & .2467 .4 \\
\hline 2543.3 & 2548.5 & $S$ & $\begin{array}{l}\text { LANL - X - Ray, O.R. 5- } \\
\text { 13-82, Shrooa }\end{array}$ & 5 & & & 2548.4 \\
\hline 2577.3 & 2577.6 & $S$ & $\begin{array}{l}\text { USGS \& T.S. LANL, } \\
\text { O.R. USGS - NR }\end{array}$ & 5 & & & 2577.4 \\
\hline Note 8 & & & & 5 & & & 2615.3 \\
\hline 2623.3 & 2623.6 & $S$ & $\begin{array}{l}\text { LANL - X-ray, O.R. 5- } \\
\text { 14-83, Bob Scott }\end{array}$ & 5 & & & 2623.4 \\
\hline $\begin{array}{r}\text { NOTES: } \\
{ }^{1} \\
3 \\
4 \\
5 \\
6 \\
7\end{array}$ & $\begin{array}{l}\text { From Sn } \\
\text { Standar } \\
\text { DTN LA } \\
\text { LANL S } \\
\text { No desc } \\
\text { LANL S } \\
\text { SMF ha } \\
\text { core box } \\
\text { No infor }\end{array}$ & $\begin{array}{l}\text { MF (Finnegan } 2 \\
\text { d whole round } \\
\text { LB831321AN9 } \\
\text { cientific Notebo } \\
\text { criptions in LAN } \\
\text { cientific Notebo } \\
\text { s indicated that } \\
\text { x, but no specifi } \\
\text { mation located }\end{array}$ & $\begin{array}{l}2001 \text { ). } \\
\text { core (S) or waxed sample } \\
8.002 \text { SEP Table } 59816 \\
\text { ok TWS-G6-8/79-50 (Boc } \\
\text { L scientific notebooks we } \\
\text { ok TWS-G-9-6/81-9, p.74 } \\
\text { the original samplers not } \\
\text { in depth intervals are prov } \\
\text { by SMF about sampling. }\end{array}$ & $\begin{array}{l}\text { (W). } \\
\text { 3_012. } \\
\text { ok 2) p. } 39 \text { throug } \\
\text { re located. } \\
\text {-75 (Caporuscio } \\
\text { ed that core sam } \\
\text { ided. }\end{array}$ & $\begin{array}{l}\text { 2001a). } \\
66 \text { (Vanima } \\
\text { ple material v }\end{array}$ & n 2001.) & from the \\
\hline
\end{tabular}


Table 6d. Detail Mapping of Samples from Collection to Analysis for USW G-3

\begin{tabular}{|c|c|c|c|c|c|c|c|}
\hline $\begin{array}{l}\text { Sample } \\
\text { From } \\
\text { (ft) }\end{array}$ & $\begin{array}{l}\text { Sample } \\
\text { To }(\mathrm{ft})^{1}\end{array}$ & $\begin{array}{c}\text { Sample } \\
\text { Designator }\end{array}$ & $\begin{array}{c}\text { Sample Management } \\
\text { Facility Records' }\end{array}$ & $\begin{array}{c}\text { Reference for } \\
\text { Sample Visual } \\
\text { Description }\end{array}$ & $\begin{array}{c}\text { Reference } \\
\text { for Notation } \\
\text { of Sample } \\
\text { Transmittal } \\
\text { / Receipt }\end{array}$ & \begin{tabular}{|c|} 
Reference \\
for Notation \\
of XRD or \\
Thin \\
Section \\
\end{tabular} & $\begin{array}{c}\text { DTN } \\
\text { Sample } \\
\text { Depth (ft) } \\
\text { for XRD } \\
\begin{array}{c}\text { Analyses at at } \\
\text { LANL }^{3}\end{array} \\
\end{array}$ \\
\hline 2615.1 & 2615.5 & $S$ & $\begin{array}{l}\text { LANL, OR } 5 / 7 / 82 \\
\text { Vaniman }\end{array}$ & 5 & 4 & & 2615.3 \\
\hline Note 6 & & & $\begin{array}{l}\text { USGS, LANL-T.S., OR } \\
5 / 7 / 82 \text {-vaniman }\end{array}$ & 6 & 4 & & 2656.6 \\
\hline 2695.6 & 2695.8 & $S$ & $\begin{array}{l}\text { LANL, OR 5/7/82 } \\
\text { Vaniman }\end{array}$ & 5 & 4 & & 2695.7 \\
\hline 2695.6 & 2695.8 & $\mathrm{~S}$ & $\begin{array}{l}\text { LANL, OR 5/7/82 } \\
\text { Vaniman }\end{array}$ & 5 & 4 & & Fracture \\
\hline 2727.3 & 2727.6 & $S$ & $\begin{array}{l}\text { LANL, OR 5/7/82 } \\
\text { Vaniman }\end{array}$ & 5 & 4 & & 2727.4 \\
\hline 2727.3 & 2727.6 & $S$ & $\begin{array}{l}\text { LANL, OR 5/7/82 } \\
\text { Vaniman }\end{array}$ & 5 & 4 & & Vein \\
\hline Note 6 & & $W$ & SNL, OR 3/4/82 & 6 & 4 & & 2914.5 \\
\hline 2970.8 & 2971.1 & $S$ & $\begin{array}{l}\text { LANL, OR } 5 / 7 / 82 \text { - Dave } \\
\text { Vaniman ( } 7 \text { pieces) }\end{array}$ & 5 & 4 & & 2971.0 \\
\hline 2970.8 & 2971.1 & $S$ & $\begin{array}{l}\text { LANL, OR } 5 / 7 / 82 \text { - Dave } \\
\text { Vaniman (7 pieces) }\end{array}$ & 5 & 4 & & Fracture \\
\hline 3004.4 & 3004.6 & $S$ & $\begin{array}{l}\text { LANL, OR 5/7/82- Dave } \\
\text { Vaniman }\end{array}$ & 5 & 4 & & 3004.5 \\
\hline 3004.4 & 3004.6 & 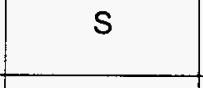 & $\begin{array}{l}\text { LANL, OR 5/7/82- Dave } \\
\text { Vaniman }\end{array}$ & 5 & 4 & & Fracture \\
\hline 3045.25 & 3045.45 & $S$ & $\begin{array}{l}\text { LANL(block reads } \\
\text { LANL, Core reads } \\
\text { USGS) }\end{array}$ & 5 & 4 & & 3045.3 \\
\hline 3112.9 & 3113.1 & $s$ & LANL, OR 5/7/82 & 5 & 4 & & 3113.1 \\
\hline 3164.0 & 3164.2 & $S$ & $\begin{array}{l}\text { LANL, OR reads } \\
3164.0-3164.3,5 / 7 / 82, \\
\text { Vaniman }\end{array}$ & 5 & 4 & & 3164.1 \\
\hline 3207.3 & 3207.5 & $S$ & $\begin{array}{l}\text { LANL, OR 5/7/82, } \\
\text { Vaniman }\end{array}$ & 5 & 4 & & 3207.4 \\
\hline 3207.3 & 3207.5 & S & $\begin{array}{l}\text { LANL, OR 5/7/82, } \\
\text { Vaniman }\end{array}$ & 5 & 4 & & Fracture \\
\hline Note 6 & & & $\begin{array}{l}\text { 3226.6, OR 5/7/82, D. } \\
\text { Vaniman-LANL }\end{array}$ & 6 & 4 & & 3226.0 \\
\hline 3238.7 & 3239.9 & S & $\begin{array}{l}\text { LANL, OR redas } \\
3238.7-3239.0\end{array}$ & 5 & 4 & & 3239.0 \\
\hline 3238.7 & 3239.9 & $\mathrm{~S}$ & $\begin{array}{l}\text { LANL, OR redas } \\
3238.7-3239.0,\end{array}$ & 5 & 4 & & Fracture \#1 \\
\hline 3238.7 & 3239.9 & $\mathrm{~s}$ & $\begin{array}{l}\text { LANL, OR redas } \\
3238.7-3239.0\end{array}$ & 5 & 4 & & Fracture \#2 \\
\hline 3310.9 & 3311.1 & $S$ & $\begin{array}{l}\text { LANL, OR 5/7/82, } \\
\text { Vaniman }\end{array}$ & 5 & 4 & & 3311.0 \\
\hline Note 6 & & & $\begin{array}{l}\text { LANL t.s., Block is } \\
\text { missing, OR reads } \\
\text { LANL }\end{array}$ & 6 & 4 & & 3475.3 \\
\hline
\end{tabular}


Table 6d. Detail Mapping of Samples from Collection to Analysis for USW G-3 (Continued)

\begin{tabular}{|c|c|c|c|c|c|c|c|}
\hline $\begin{array}{l}\text { Sample } \\
\text { From } \\
\text { (ft) })^{1}\end{array}$ & $\begin{array}{l}\text { Sample } \\
\text { To }(\mathrm{ft})^{1}\end{array}$ & \begin{tabular}{|c|} 
Sample \\
Designator
\end{tabular} & $\begin{array}{c}\text { Sample Management } \\
\text { Facility Records }^{1}\end{array}$ & $\begin{array}{c}\text { Reference for } \\
\text { Sample Visual } \\
\text { Description }\end{array}$ & $\begin{array}{c}\text { Reference } \\
\text { for Notation } \\
\text { of Sample } \\
\text { Transmittal } \\
\text { / Receipt }\end{array}$ & $\begin{array}{c}\text { Reference } \\
\text { for Notation } \\
\text { of XRD or } \\
\text { Thin } \\
\text { Section }\end{array}$ & \begin{tabular}{|c|} 
DTN \\
Sample \\
Depth (ft) \\
for XRD \\
$\begin{array}{c}\text { Analyses at } \\
\text { LANL }^{3}\end{array}$ \\
\end{tabular} \\
\hline 3589.25 & 3589.65 & $s$ & $\begin{array}{l}\text { LANL, OR 5/7/82, Dave } \\
\text { Vaniman }\end{array}$ & 5 & 4 & & 3589.4 \\
\hline Note 6 & & & $\begin{array}{l}\text { USGS, LANL t.s., Block } \\
\text { is missing, OR reads }\end{array}$ & 6 & 4 & & 3672.0 \\
\hline Note 6 & . & & \begin{tabular}{|l|} 
LANL-USGS t.s., OR \\
$3959.0,3 / 19 / 82$
\end{tabular} & 6 & 4 & & 3759.1 \\
\hline Note 6 & & & $\begin{array}{l}\text { sharon deihl, USGS or } \\
\text { LANL } 3854.7 \text {, or } \\
3854.9,5 / 7 / 82 \text {, D. } \\
\text { vaniman written on core }\end{array}$ & 6 & 4 & & 3854.8 \\
\hline 3859.2 & 3859.7 & $\mathrm{~s}$ & $\begin{array}{l}\text { LANL, OR 3859.2- } \\
3859.555 / 7 / 82, \\
\text { Vaniman } \\
\end{array}$ & 5 & 4 & & 3859.3 \\
\hline 3936.25 & 3936.45 & s & $\begin{array}{l}\text { LANL, OR 5/7/82, } \\
\text { Vaniman } \\
\end{array}$ & 5 & 4 & & 3936.3 \\
\hline Note 6 & & & $\begin{array}{l}\text { USGS t.s.-LANL t.s., } \\
\text { No block, OR USGS } \\
\text { 4/28/83 Warner, OR } \\
\text { LANL 5/7/82 Vaniman }\end{array}$ & 6 & 4 & & 4008.3 \\
\hline 4116.75 & 4117.0 & $S$ & $\begin{array}{l}\text { LANL, OR } 5 / 7 / 82 \text {, Dave } \\
\text { Vaniman }\end{array}$ & 5 & 4 & & 4117.0 \\
\hline Note 6 & & W & SNL, OR 3/19/82 & 6 & 4 & & 4240.6 \\
\hline 4263.6 & 4263.9 & $S$ & $\begin{array}{l}\text { LANL, OR 5/7/82- } \\
\text { Vaniman }\end{array}$ & 5 & 4 & & 4263.8 \\
\hline 4297.5 & 4297.7 & $\mathrm{~S}$ & LANL, OR NR & 5 & 4 & & 4297.1 \\
\hline 4415.8 & 4416.2 & $S$ & $\begin{array}{l}\text { LANL, OR } 5 / 7 / 82 \text {, Dave } \\
\text { Vaniman }\end{array}$ & 5 & 4 & & 4416.0 \\
\hline Note 6 & & & $\begin{array}{l}\text { LANL-GSOS-t.s., block } \\
\text { is missing, LANL-OR }\end{array}$ & 6 & 4 & & 4423.0 \\
\hline 4503.7 & 4503.8 & $s$ & $\begin{array}{l}\text { LANL, OR 5/7/82, } \\
\text { Vaniman } \\
\end{array}$ & 5 & 4 & & 4503.7 \\
\hline 4503.7 & 4503.8 & $S$ & $\begin{array}{l}\text { LANL, OR 5/7/82, } \\
\text { Vaniman }\end{array}$ & 5 & 4 & & Fracture \\
\hline 4297.5 & 4297.7 & $s$ & LANL, OR NR & 5 & 4 & & Fracture \\
\hline Note 6 & & & $\begin{array}{l}\text { t.s. LANL, Block } \\
\text { missing, LANL OR } \\
\text { reads 5/7/82 Dave } \\
\text { Vaniman } \\
\end{array}$ & 6 & 4 & & 4600.3 \\
\hline Note 6 & & & $\begin{array}{l}\text { t.s. LANL, Block is } \\
\text { missing, LANL-OR } \\
\text { reads } 5 / 7 / 82 \text { Dave } \\
\text { Vaniman }\end{array}$ & 6 & 4 & & 4708.5 \\
\hline Note 6 & & & $\begin{array}{l}\text { LANL t.s., OR LANL } \\
5 / 7 / 82-V a n i m a n\end{array}$ & 6 & 4 & & 4756.5 \\
\hline 4786.3 & 4786.6 & $s$ & $\begin{array}{l}\text { LANL, OR } 5 / 7 / 82 \text {, Dave } \\
\text { Vaniman }\end{array}$ & 5 & 4 & & 4786.4 \\
\hline
\end{tabular}


Table 6d. Detail Mapping of Samples from Collection to Analysis for USW G-3 (Continued)

\begin{tabular}{|c|c|c|c|c|c|c|c|}
\hline $\begin{array}{c}\text { Sample } \\
\text { From } \\
(\mathrm{ft})^{1}\end{array}$ & $\begin{array}{l}\text { Sample } \\
\text { To }(\mathrm{ft})^{1}\end{array}$ & $\begin{array}{c}\text { Sample } \\
\text { Designator }\end{array}$ & $\begin{array}{l}\text { Sample Management } \\
\text { Facility Records }\end{array}$ & $\begin{array}{l}\text { Reference for } \\
\text { Sample Visual } \\
\text { Description }\end{array}$ & $\begin{array}{c}\text { Reference } \\
\text { for Notation } \\
\text { of Sample } \\
\text { Transmittal } \\
\text { / Receipt }\end{array}$ & $\begin{array}{l}\text { Reference } \\
\text { for Notation } \\
\text { of XRD or } \\
\text { Thin } \\
\text { Section }\end{array}$ & $\begin{array}{c}\text { DTN } \\
\text { Sample } \\
\text { Depth (ft) } \\
\text { for XRD } \\
\text { Analyses at } \text { LANL }^{3} \\
\end{array}$ \\
\hline 4803.0 & 4803.3 & $S$ & $\begin{array}{l}\text { LANL, OR } 5 / 7 / 82- \\
\text { Vaniman }\end{array}$ & 5 & 4 & & 4803.2 \\
\hline 4803.0 & 4803.3 & $S$ & $\begin{array}{l}\text { LANL, OR } 5 / 7 / 82- \\
\text { Vaniman }\end{array}$ & 5 & 4 & & Vein \\
\hline 4869.3 & 4869.5 & $\mathrm{~S}$ & $\begin{array}{l}\text { LANL, OR } 5 / 7 / 82 \text {, Dave } \\
\text { vaniman }\end{array}$ & 5 & 4 & & 4869.4 \\
\hline Note 6 & & & $\begin{array}{l}\text { LANL t.s., OR 12/16/82, } \\
\text { R. Runberg }\end{array}$ & 6 & 4 & & 4906.5 \\
\hline 5013.8 & 5014.0 & $S$ & $\begin{array}{l}\text { LANL t.S., OR } 5 / 7 / 82 \text {, } \\
\text { Vaniman }\end{array}$ & 5 & 4 & & 5014.0 \\
\hline $\begin{array}{r}\text { NOTES: } \\
2 \\
3 \\
4 \\
5 \\
6\end{array}$ & $\begin{array}{l}\text { From SA } \\
\text { Standarc } \\
\text { DTN LA } \\
\text { LANL Sc } \\
\text { LANL Sc } \\
\text { SMF has } \\
\text { box, but }\end{array}$ & $\begin{array}{l}\text { MF (Finnegan } 2 \\
\text { d whole round c } \\
\text { DB831321AN98 } \\
\text { cientific Notebor } \\
\text { cientific Noteboc } \\
\text { s indicated that } \\
\text { no specific dep }\end{array}$ & $\begin{array}{l}\text { con). } \\
\text { core (S) or waxed sample } \\
\text { ok TWS-G-9-6/81-9, p. } \\
\text { ok TWS-G-6-8/79-50, p.3 } \\
\text { the original samplers not } \\
\text { oth intervals are provided. }\end{array}$ & $\begin{array}{l}(\text { W). } \\
\text { 3_012. } \\
5 \text { (Caporuscio } 20 \\
9-51 \text { (Vaniman } 2 \\
\text { ed that core sam }\end{array}$ & $\begin{array}{l}\text { 01a). } \\
\text { no1). } \\
\text { nple material }\end{array}$ & was removed $f$ & from the core \\
\hline
\end{tabular}


Table 6e. Detailed Mapping of Samples from Collection to Analysis for USW G-4

\begin{tabular}{|c|c|c|c|c|c|c|c|}
\hline $\begin{array}{l}\text { Sample } \\
\text { From } \\
\left(\mathrm{ft}^{1}\right)^{1}\end{array}$ & $\begin{array}{l}\text { Sample } \\
{\text { To }(\mathrm{ft})^{1}}^{1}\end{array}$ & $\begin{array}{c}\text { Sample } \\
\text { Designator }\end{array}$ & $\begin{array}{c}\text { Sample Management } \\
\text { Facility Records }^{3}\end{array}$ & $\begin{array}{c}\text { Reference for } \\
\text { Sample Visual } \\
\text { Description }\end{array}$ & $\begin{array}{l}\text { Reference } \\
\text { for Notation } \\
\text { of Sample } \\
\text { Transmittal } \\
\text { / Receipt }\end{array}$ & $\begin{array}{c}\text { Reference } \\
\text { for Notation } \\
\text { of XRD or } \\
\text { Thin } \\
\text { Section } \\
\end{array}$ & $\begin{array}{c}\text { DTN } \\
\text { Sample } \\
\text { Depth (ft) } \\
\text { for XRD } \\
\begin{array}{c}\text { Analyses at } \\
\text { LANL }^{3}\end{array} \\
\end{array}$ \\
\hline & & S & $\begin{array}{l}\text { LANL - Byers, F. } \\
12 / 14 / 82\end{array}$ & 4 & 6 & 6 & 47 \\
\hline 72.0 & 72.3 & 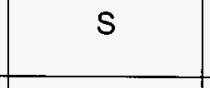 & \begin{tabular}{|l|} 
LANL - Byers, F. \\
10/29/82
\end{tabular} & 4 & 6 & 6 & 72 \\
\hline 107.0 & 107.2 & $\mathrm{~s}$ & LANL - Byers $10 / 29 / 82$ & 4 & 6 & 6 & 107 \\
\hline 123.2 & 123.4 & $s$ & LANL - Byers 12/14/82 & 4 & 6 & 6 & 123 \\
\hline 148.3 & 148.4 & $S$ & LANL/USGS 12/14/82 & 4 & 6 & 6 & 148 \\
\hline 169.8 & 170.0 & $S$ & LANL - Byers 12/14/82 & 4 & 6 & 6 & 170 \\
\hline 219.7 & 220.0 & $S$ & LANL - Byers 12/14/82 & 4 & 6 & 6 & 220 \\
\hline 231.0 & 231.2 & $s$ & LANL - Byers $12 / 14 / 82$ & 4 & 6 & 6 & 231 \\
\hline 236.3 & 236.5 & $\underline{s}$ & LANL - Byers $12 / 14 / 82$ & 4 & 6 & 6 & 236 \\
\hline 268.1 & 268.3 & $s$ & LANL - Byers $12 / 14 / 82$ & 4 & 6 & 6 & 268 \\
\hline 280.8 & 281.0 & $s$ & LANL - unk & 4 & 6 & 6 & 280 \\
\hline 332.6 & 332.8 & $s$ & LANL - Byers $12 / 14 / 82$ & 4 & 6 & 6 & 332 \\
\hline 383.0 & 383.3 & s & LANL - Byers 10/29/82 & 4 & 6 & 6 & 383 \\
\hline 409.9 & 410.2 & $s$ & \begin{tabular}{|l|} 
LANL - Byers \\
$10 / 29 / 82$
\end{tabular} & 4 & 6 & 6 & 410 \\
\hline 416.0 & 416.3 & $\mathrm{~s}$ & LANL - Byers 10/29/82 & 4 & 6 & 6 & 416 \\
\hline 446.9 & 447.0 & S & LANL - Byers 10/29/82 & 4 & 6 & 6 & 447 \\
\hline 514.3 & 514.5 & $s$ & LANL - Byers $10 / 29 / 82$ & 4 & 6 & 6 & 514 \\
\hline 555.7 & 556.0 & S & LANL - unk & 4 & 6 & 6 & 556 \\
\hline 625.3 & 625.5 & $S$ & LANL - Byers $10 / 29 / 82$ & 4 & 6 & 6 & 625 \\
\hline 676.6 & 676.7 & $S$ & LANL - 10/29/82 & 4 & 6 & 6 & 676 \\
\hline 694.0 & 694.4 & $s$ & $\begin{array}{l}\text { LANL - thin section } \\
\text { 10/29/82 }\end{array}$ & 4 & 6 & 6 & 694 \\
\hline 746.4 & 746.7 & $s$ & LANL - Byers 10/29/82 & 4 & 6 & 6 & 746 \\
\hline 816.9 & 817.2 & $s$ & LANL - Byers 10/29/82 & 4 & 6 & 6 & 817 \\
\hline 934.2 & 934.4 & $s$ & LANL - Byers $10 / 29 / 82$ & 4 & 6 & 6 & 934 \\
\hline 1026.4 & 1026.8 & $s$ & LANL - Byers 10/29/83 & 4 & 6 & 6 & 1026 \\
\hline 1088.6 & 1089.0 & $S$ & LANL - Byers 10/29/82 & 4 & 6 & 6 & 1089 \\
\hline 1088.6 & 1089.0 & $S$ & LANL - Byers 10/29/82 & 4 & 6 & 6 & Fracture \\
\hline 1117.4 & 1117.8 & $S$ & LANL - Byers 10/29/82 & 4 & 6 & 6 & 1117 \\
\hline 1163.2 & 1163.3 & $s$ & LANL - Byers 10/29/82 & 4 & 6 & 6 & 1163 \\
\hline 1163.2 & 1163.3 & $\underline{s}$ & LANL - Byers 10/29/82 & 4 & 6 & 6 & Inclusion \\
\hline 1190.3 & 1190.7 & $\mathrm{~s}$ & LANL - nothing in OR & 4 & 6 & 6 & 1190 \\
\hline 1244.3 & 1244.5 & $\mathrm{~S}$ & LANL - Byers 10/29/82 & 4 & 6 & 6 & 1244 \\
\hline 1281.9 & 1282.1 & $\mathrm{~s}$ & LANL - Byers 10/29/82 & 4 & 6 & 6 & 1282 \\
\hline 1283.0 & 1293.0 & $s$ & LANL - Byers 12/29/82 & 4 & 6 & 6 & 1283-1293E \\
\hline 1299.0 & 1299.3 & $s$ & LANL - Byers 10/29/82 & 4 & 6 & 6 & 1299 \\
\hline 1301.2 & 1301.8 & $s$ & LANL - Byers 10/29/82 & 4 & 6 & 6 & 1301 \\
\hline 1310.4 & 1310.9 & S & LANL - Byers 10/29/82 & 4 & 6 & 6 & 1310 \\
\hline
\end{tabular}


Table 6e. Detailed Mapping of Samples from Collection to Analysis for USW G-4 (Continued)

\begin{tabular}{|c|c|c|c|c|c|c|c|}
\hline $\begin{array}{l}\text { Sample } \\
\text { From } \\
(\mathrm{ft})^{1}\end{array}$ & $\begin{array}{l}\text { Sample } \\
\text { To (ft) }\end{array}$ & $\begin{array}{c}\text { Sample } \\
\text { Designator }\end{array}$ & $\begin{array}{l}\text { Sample Management } \\
\text { Facility Records }^{3}\end{array}$ & $\begin{array}{c}\text { Reference for } \\
\text { Sample Visual } \\
\text { Description }\end{array}$ & $\begin{array}{c}\text { Reference } \\
\text { for Notation } \\
\text { of Sample } \\
\text { Transmittal } \\
\text { / Receipt }\end{array}$ & $\begin{array}{c}\text { Reference } \\
\text { for Notation } \\
\text { of XRD or } \\
\text { Thin } \\
\text { Section } \\
\end{array}$ & $\begin{array}{c}\text { DTN } \\
\text { Sample } \\
\text { Depth (ft) } \\
\text { for XRD } \\
\text { Analyses at } \\
\text { LANL }^{3}\end{array}$ \\
\hline 1314.4 & 1314.6 & $s$ & LANL - Byers 10/29/82 & 4 & 6 & 6 & 1314 \\
\hline 1330.7 & 1330.9 & $S$ & LANL - Byers 10/29/82 & 4 & 6 & 6 & 1330 \\
\hline 1341.7 & 1341.9 & $S$ & $\begin{array}{l}\text { LANL - Carlos-Byers } \\
11 / 21 / 83\end{array}$ & 4 & 6 & 6 & 1341 \\
\hline 1371.2 & 1371.6 & $S$ & LANL - Carlos 4/21/83 & 4 & 7 & 7 & 1372 \\
\hline 1381.4 & 1381.7 & $S$ & LANL - Byers 10/29/82 & 4 & 6 & 6 & 1381 \\
\hline 1381.4 & 1381.7 & $S$ & LANL - Byers 10/29/82 & 4 & 6 & 6 & Inclusion \\
\hline 1392.2 & 1392.5 & $S$ & LANL - Byers 10/29/82 & 4 & 6 & 6 & 1392 \\
\hline 1392.2 & 1392.5 & $S$ & LANL - Byers 10/29/82 & 4 & 6 & 6 & Inclusion \\
\hline 1419.0 & 1419.2 & $S$ & LANL - Byers 10/29/82 & 4 & 6 & 6 & 1419 \\
\hline 1431.8 & 1432.0 & $S$ & $\begin{array}{l}\text { LANL - Byers 10/29/82 } \\
\text { thin sec. }\end{array}$ & 4 & 6 & 6 & 1432 \\
\hline 1438.1 & 1438.6 & $S$ & LANL - Byers 10/29/82 & 4 & 6 & 6 & 1438 \\
\hline 1469.9 & 1470.3 & $\mathrm{~S}$ & LANL - Byers 10/29/82 & 4 & 6 & 6 & 1470 \\
\hline 1544.3 & 1544.6 & $s$ & LANL - Byers $10 / 29 / 82$ & 4 & 6 & 6 & 1544 \\
\hline 1601.8 & 1602.1 & $S$ & $\begin{array}{l}\text { LANL - Byers 10/29/82 } \\
\text { thin sec. }\end{array}$ & 4 & 6 & 6 & 1602 \\
\hline 1685.2 & 1685.4 & $S$ & $\begin{array}{l}\text { LANL, O.R., Thin } \\
\text { Section, Byers, } \\
10 / 28 / 82\end{array}$ & 4 & 6 & 6 & 1685 \\
\hline 1706.9 & 1707.1 & $S$ & $\begin{array}{l}\text { LANL, corrected } \\
1706.0-1706.2 \mathrm{KAS}, \\
\text { O.R., Byers, 10/29/82 }\end{array}$ & 4 & 6 & 6 & 1707 \\
\hline 1734.3 & 1734.6 & $\mathrm{~S}$ & & 4 & 6 & 6 & 1734 \\
\hline 1763.2 & 1763.5 & $\mathrm{~S}$ & $\begin{array}{l}\text { O.R., LANL, Byers, } \\
12 / 14 / 82\end{array}$ & 4 & 6 & 6 & 1763 \\
\hline 1779.6 & 1779.9 & $\mathrm{~S}$ & $\begin{array}{l}\text { LANL, other side of } \\
\text { USGS spc., O.R., } \\
\text { Byers, } 12 / 14 / 82\end{array}$ & 4 & 6 & 6 & 1779 \\
\hline 1788.4 & 1788.9 & $\mathrm{~S}$ & $\begin{array}{l}\text { LANL, O.R., Byers \& } \\
\text { Carlos, } 12 / 14 / 82\end{array}$ & 4 & 6 & 6 & 1788 \\
\hline 1788.4 & 1788.9 & $\mathrm{~S}$ & $\begin{array}{l}\text { LANL, O.R., Byers \& } \\
\text { Carlos, } 12 / 14 / 82\end{array}$ & 4 & 6 & 6 & Fracture \\
\hline 1794.2 & 1794.7 & $S$ & $\begin{array}{l}\text { LANL, O.R., Byers, } \\
12 / 14 / 82\end{array}$ & 4 & 6 & 6 & 1794 \\
\hline 1840.9 & 1841.2 & $S$ & $\begin{array}{l}\text { LANL, O.R., Byers, } \\
12 / 14 / 82\end{array}$ & 4 & 6 & 6 & 1841 \\
\hline 1871.6 & 1871.8 & $S$ & $\begin{array}{l}\text { O.R.,LANL, Byers, } \\
12 / 14 / 82\end{array}$ & 4 & 6 & 6 & 1871 \\
\hline 1938.7 & 1939.0 & $S$ & $\begin{array}{l}\text { LANL,O.R., thin } \\
\text { section, Byers, } \\
12 / 14 / 82\end{array}$ & 4 & 6 & 6 & 1938 \\
\hline 1952.8 & 1953.0 & $S$ & $\begin{array}{l}\text { O.R., LANL, Byers, } \\
12 / 14 / 82\end{array}$ & 4 & 6 & 6 & 1952 \\
\hline
\end{tabular}


Table 6e. Detailed Mapping of Samples from Collection to Analysis for USW G-4 (Continued)

\begin{tabular}{|c|c|c|c|c|c|c|c|}
\hline $\begin{array}{c}\text { Sample } \\
\text { From } \\
\text { (ft) }\end{array}$ & $\begin{array}{l}\text { Sample } \\
\text { To }(\mathrm{ft})^{1}\end{array}$ & $\begin{array}{c}\text { Sample } \\
\text { Designator }\end{array}$ & $\begin{array}{l}\text { Sample Management } \\
\text { Facility Records }^{3}\end{array}$ & $\begin{array}{c}\text { Reference for } \\
\text { Sample Visual } \\
\text { Description }\end{array}$ & $\begin{array}{c}\text { Reference } \\
\text { for Notation } \\
\text { of Sample } \\
\text { Transmittal } \\
\text { / Receipt }\end{array}$ & \begin{tabular}{|c|} 
Reference \\
for Notation \\
of XRD or \\
Thin \\
Section
\end{tabular} & $\begin{array}{c}\text { DTN } \\
\text { Sample } \\
\text { Depth (ft) } \\
\text { for XRD } \\
\begin{array}{c}\text { Analyses at } \\
\text { LANL }^{3}\end{array} \\
\end{array}$ \\
\hline 1958.3 & 1958.6 & $\mathrm{~s}$ & $\begin{array}{l}\text { O.R.,LANL, Carlos, } \\
\text { 8/30/83 }\end{array}$ & 5 & 6 & 6 & $1958 \mathrm{~b}$ \\
\hline 1968.7 & 1969.0 & $S$ & $\begin{array}{l}\text { O.R.,LANL, Byers, } \\
\text { 12/14/82 }\end{array}$ & 4 & 6 & 6 & 1968 \\
\hline 1989.2 & 1989.4 & $S$ & $\begin{array}{l}\text { LANL, O.R., Byers, } \\
12 / 14 / 82\end{array}$ & 4 & 6 & 6 & 1989 \\
\hline 2038.9 & 2039.0 & $S$ & $\begin{array}{l}\text { LANL, O.R.,Byers, } \\
12 / 14 / 82\end{array}$ & 4 & 6 & 6 & 2039 \\
\hline 2069.1 & 2069.3 & $S$ & $\begin{array}{l}\text { O.R., LANL, Byers, } \\
12 / 14 / 82\end{array}$ & 4 & 6 & 6 & 2069 \\
\hline 2090.1 & 2090.4 & $S$ & LANL, Byers, $12 / 14 / 82$ & 4 & 6 & 6 & 2090 \\
\hline 2100.4 & 2100.5 & $S$ & $\begin{array}{l}\text { LANL, O.R., Byers, } \\
12 / 14 / 82\end{array}$ & 4 & 6 & 6 & 2100 \\
\hline 2100.9 & 2101.0 & $S$ & $\begin{array}{l}\text { LANL, O.R., Byers, } \\
12 / 14 / 82\end{array}$ & 4 & 7 & 7 & $\begin{array}{l}2100- \\
\text { Fracture }\end{array}$ \\
\hline 2131.7 & 2132.0 & $S$ & $\begin{array}{l}\text { LANL, O.R., Byers, } \\
\text { 12/14/82 }\end{array}$ & 4 & 6 & 6 & 2131 \\
\hline 2202.4 & 2202.8 & $s$ & $\begin{array}{l}\text { LANL. O.R., Byers, } \\
12 / 14 / 82\end{array}$ & 4 & 6 & 6 & 2202 \\
\hline 2226.5 & 2226.7 & $s$ & $\begin{array}{l}\text { LANL, O.R., } \\
\text { Byers,12/14/82 }\end{array}$ & 4 & 6 & 6 & 2226 \\
\hline 2238.5 & 2238.7 & $s$ & $\begin{array}{l}\text { LANL, O.R., Byers, } \\
\text { 12/14/82 }\end{array}$ & 4 & 6 & 6 & 2238 \\
\hline 2247.7 & 2248.0 & $S$ & $\begin{array}{l}\text { LANL,O.R., Carlos, } \\
\text { 9/1/83 }\end{array}$ & 5 & 6 & 6 & $2248 b$ \\
\hline 2263.6 & 2263.8 & $S$ & $\begin{array}{l}\text { LANL, O.R., Byers, } \\
12 / 14 / 82\end{array}$ & 4 & 6 & 6 & 2263 \\
\hline 2285.1 & 2285.3 & S & $\begin{array}{l}\text { O.R., Beyers, LANL, } \\
11 / 14 / 82\end{array}$ & 4 & 6 & 6 & 2285 \\
\hline 2343.3 & 2343.6 & $S$ & $\begin{array}{l}\text { LANL, O.R., Byers, } \\
12 / 14 / 82\end{array}$ & 4 & 6 & 6 & 2343 \\
\hline 2343.3 & 2343.6 & $\mathrm{~s}$ & $\begin{array}{l}\text { LANL, O.R., Byers, } \\
\text { 12/14/82 }\end{array}$ & 4 & 6 & 6 & Fracture1 \\
\hline 2343.3 & 2343.6 & $\mathrm{~s}$ & $\begin{array}{l}\text { LANL, O.R., Byers, } \\
12 / 14 / 82\end{array}$ & 4 & 6 & 6 & Fracture2 \\
\hline 2354.9 & 2355.0 & $\mathrm{~s}$ & $\begin{array}{l}\text { LANL, O.R., Byers, } \\
12 / 14 / 82\end{array}$ & 4 & 6 & 6 & 2355 \\
\hline 2381.1 & 2381.3 & $\mathrm{~s}$ & $\begin{array}{l}\text { LANL, O.R., Byers, } \\
12 / 14 / 82\end{array}$ & 4 & 6 & 6 & 2381 \\
\hline 2423.3 & 2423.4 & $\mathrm{~s}$ & $\begin{array}{l}\text { LANL, O.R., Byers, } \\
12 / 14 / 82\end{array}$ & 4 & 6 & 6 & 2423 \\
\hline 2516.6 & 2516.8 & $\mathrm{~s}$ & $\begin{array}{l}\text { O.R., LANL, Beyers, } \\
\text { 12/14/82 }\end{array}$ & 4 & 6 & 6 & 2516 \\
\hline
\end{tabular}


Table 6e. Detailed Mapping of Samples from Collection to Analysis for USW G-4 (Continued)

\begin{tabular}{|c|c|c|c|c|c|c|c|}
\hline $\begin{array}{c}\text { Sample } \\
\text { From } \\
(\mathrm{ft})^{1}\end{array}$ & $\begin{array}{l}\text { Sample } \\
\text { To }(\mathrm{ft})^{1}\end{array}$ & $\begin{array}{c}\text { Sample } \\
\text { Designator }\end{array}$ & $\begin{array}{c}\text { Sample Management } \\
\text { Facility Records }^{3}\end{array}$ & \begin{tabular}{|c} 
Reference for \\
Sample Visual \\
Description
\end{tabular} & $\begin{array}{c}\text { Reference } \\
\text { for Notation } \\
\text { of Sample } \\
\text { Transmittal } \\
\text { / Receipt }\end{array}$ & \begin{tabular}{|c|} 
Reference \\
for Notation \\
of XRD or \\
Thin \\
Section \\
\end{tabular} & $\begin{array}{c}\text { DTN } \\
\text { Sample } \\
\text { Depth (ft) } \\
\text { for XRD } \\
\text { Analyses at } \\
\text { LANL }^{3} \\
\end{array}$ \\
\hline 2533.6 & 2533.8 & $S$ & $\begin{array}{l}\text { O.R., LANL, Beyers, } \\
12 / 14 / 82\end{array}$ & 4 & 6 & 6 & 2533 \\
\hline 2551.7 & 2551.9 & $S$ & $\begin{array}{l}\text { O.R., LANL, Byers, } \\
12 / 14 / 82\end{array}$ & 4 & 6 & 6 & 2551 \\
\hline 2566.0 & 2566.3 & $\mathrm{~s}$ & $\begin{array}{l}\text { LANL, O.R., Byers, } \\
12 / 14 / 82\end{array}$ & 4 & 6 & 6 & 2566 \\
\hline 2598.5 & 2598.8 & $S$ & $\begin{array}{l}\text { O.R., LANL, Byers, } \\
12 / 14 / 82\end{array}$ & 4 & 6 & 6 & 2598 \\
\hline 2681.2 & 2681.4 & $S$ & $\begin{array}{l}\text { O.R., LANL, Byers, } \\
12 / 14 / 82\end{array}$ & 4 & 6 & 6 & 2681 \\
\hline 2716.5 & 2716.8 & $S$ & $\begin{array}{l}\text { O.R., LANL, Byers, } \\
\text { 12/14/82 }\end{array}$ & 4 & 6 & 6 & 2716 \\
\hline 2731.2 & 2731.5 & $S$ & $\begin{array}{l}\text { O.R., LANL, Byers, } \\
12 / 14 / 82\end{array}$ & 4 & 6 & 6 & 2731 \\
\hline 2754.7 & 2754.9 & $S$ & $\begin{array}{l}\text { O.R., LANL, Byers, } \\
12 / 14 / 82\end{array}$ & 4 & 6 & 6 & 2754 \\
\hline 2758.4 & 2758.6 & $\mathrm{~s}$ & $\begin{array}{l}\text { O.R., Byers, LANL, } \\
12 / 14 / 82\end{array}$ & 4 & 6 & 6 & 2758 \\
\hline 2762.7 & 2763.0 & $S$ & $\begin{array}{l}\text { O.R., LANL, Byers, } \\
12 / 14 / 82\end{array}$ & 4 & 6 & 6 & 2762 \\
\hline 2792.2 & 2793.0 & $S$ & $\begin{array}{l}\text { O.R. LANL Beyer } \\
12 / 14 / 82\end{array}$ & 4 & 6 & 6 & 2792 \\
\hline 2822.8 & 2823.1 & $S$ & $\begin{array}{l}\text { O.R. LANL Beyers } \\
12 / 14 / 82\end{array}$ & 4 & 6 & 6 & 2823 \\
\hline 2822.8 & 2823.1 & $S$ & $\begin{array}{l}\text { O.R. LANL Beyers } \\
12 / 14 / 82\end{array}$ & 4 & 6 & 6 & $\begin{array}{c}2823- \\
\text { Fracture }\end{array}$ \\
\hline 2837.7 & 2838.0 & $S$ & $\begin{array}{l}\text { O.R., LANL, Carlos, } \\
\text { 9/1/83 }\end{array}$ & 5 & 6 & 6 & $2838 b$ \\
\hline 2840.5 & 2840.8 & $S$ & $\begin{array}{l}\text { O.R., LANL, Beyers, } \\
12 / 14 / 82\end{array}$ & 4 & 6 & 6 & 2840 \\
\hline 2875.3 & 2875.7 & $S$ & $\begin{array}{l}\text { O.R. LANL Beyers } \\
\text { 12/14/82 }\end{array}$ & 4 & 6 & 6 & 2875 \\
\hline & & & & 5 & 6 & 6 & $2931 b$ \\
\hline & & & & 4 & 6 & 6 & 2947 \\
\hline & & & & 4 & 6 & 6 & $\begin{array}{c}2947- \\
\text { Fracture }\end{array}$ \\
\hline 3000.7 & 3000.9 & S & $\begin{array}{l}\text { O.R., LANL / Byers, } \\
12 / 14 / 82\end{array}$ & 4 & 6 & 6 & 3000 \\
\hline NOTES: & $\begin{array}{l}\text { From SA } \\
\text { Standar } \\
\text { DTN LA } \\
\text { LANL Sc } \\
\text { Listed as } \\
\text { 2001a). } \\
\text { LANL Sc } \\
\text { LANL Sc }\end{array}$ & $\begin{array}{l}\text { MF (Finnegan } 2 \\
\text { d whole round c } \\
\text { DB831321AN9 } \\
\text { cientific Notebo } \\
\text { s part of the res } \\
\text { cientific Notebo }\end{array}$ & $\begin{array}{l}\text { 2001). } \\
\text { core (S). } \\
8.002 \text {; SEP Table S9816 } \\
\text { ok TWS-ESS-1-10/82-25 } \\
\text { sampling in LANL Scientif } \\
\text { ok TWS-ESS-1-4/87-33, } \\
\text { ok TWS-G9-6/81-9, p. } 97\end{array}$ & $\begin{array}{l}\text { 3_010. } \\
\text { p. 1-13, 20-31 } \\
\text { ic Notebook TWS } \\
\text { p. } 80-81 \text { (Semars }\end{array}$ & $\begin{array}{l}\text { Byers 2001). } \\
\text { S-G-9-6/81-9, } \\
\text { ge 1983). } \\
\text { o 2001a) }\end{array}$ & p. 126,144 (C & Caporuscio \\
\hline
\end{tabular}




\subsubsection{Core Warehouse}

When a sample was removed from the core by the LANL investigators, some indication was left with the remaining core. For example, a wooden block or spacer was most often left in the place of the sample, with a notation on the block of the depth, investigator's name, and organization. In other cases, notations were written on the remaining core or notes were left on sheets of paper and left in the core boxes. In an attempt to confirm that the samples were actually removed, the Data Qualification Team examined records recently updated by the SMF (Finnegan 2001).

These records were compiled by the SMF personnel both from files, and by actual examination of remaining core material in all core boxes. The files provided by the SMF identify every location in the core from which a sample has been taken that can be documented (Finnegan 2001). Each sample number (or depth) listed in DTN LADB831321AN98.002 was compared with the SMF record, and this information is listed in Tables 6a-e, columns 1 through 4 , for each of the five core that were reviewed in detail. Columns 1 and 2 indicate, where available, the exact interval in feet from which a core sample was removed. Column 3 is a description of the type of sample (e.g., whole core, which is the standard sample, as opposed to a small fragment, or a piece immersed in wax for preservation). Column 4 is a tabulation of the information left by the sampling organization identifying the agency and investigators.

The Data Qualification Team considers the information from the SMF to be some of the most compelling evidence. Note that there is a remarkable correlation between the sampled intervals as noted in columns 1 and 2, and the depth notation for the sample analyzed (column 8). Note also that for well USW G-3 there is 100 percent correlation and for wells USW G-4 and UE-25b\#1 there is 96 percent and 97 percent correlation, respectively. The unmatched samples from USW G-4, UE-25b\#1, USW G-1, and USW GU-3 should be interpreted as follows. The SMF does not identify whether a sample has been removed if no records exist. These samples were undoubtedly taken, but the SMF has not found a record identifying such in the core box. Laboratory records were considered adequate to justify inclusion of data from those samples, since they are compatible with the completely documented samples.

As will be noted in subsequent sections, other records exist supporting the removal of the core pieces. Such a complete one-to-one correlation between the sample depths listed in the DTNs versus the sample depths of removed core, as noted by the SMF (e.g., wooden blocks, or paper records), supports the contention that the samples were removed correctly (Tables $6 a$ through 6e).

\subsubsection{Field Hand Descriptions of Collected Samples}

There was no established YMP sampling procedure across the site at this early date; however, there was a LANL QA core sampling procedure (TWS-G6-1/79-24) in place as early as March 5, 1979, written by Martha Sykes and technically reviewed by Joseph Smyth. Both Sykes and Smyth are among the first scientists to actually collect samples used for DTN LADB831321 AN98.002, and they established the precedent of noting descriptions to be used in subsequent sampling trips. Most of the samples for this DTN were collected by various combinations of the same personnel in the LANL Earth and Environmental Sciences Division using this same procedure. The procedure states that the core samples "... are selected at the site 
by qualified Los Alamos Scientific Lab staff geologists." And that “... sample number, depth from the surface of the drill hole, and a brief hand specimen lithologic description are recorded for each sample." (TWS-G6-1/79-24). It is clear that the LANL investigators knew that sample selection required competent scientists and field documentation. Scientific Notebooks and other publications that contain the sample descriptions done at the USGS Core Warehouse are referenced in column 5 of the Tables $6 \mathrm{a}-\mathrm{e}$ for each well.

A sample description in a Scientific Notebook generally was an entry in which the exact interval sampled was noted, followed by a brief lithologic description of the core as it was examined as a hand specimen. In some cases, a general description was provided for a range of samples. A large number of these descriptions have been located. For UE-25b\#1, USW G-3, USW G-4, and USW G-1, 100 percent of the descriptions have been located and can be referenced. These depths can be correlated to the SMF record and the depth (sample number) of the sample analyzed by XRD (Tables 6a through 6e).

Of the nine boreholes with core drilled from 1978 to 1983 (Table 4a) sample descriptions are available in varying degrees of completeness from all of the boreholes. Table 5 provides the references to these descriptions. Table 5 is a summary of the pages from the Scientific Notebooks located to date by the Data Qualification Team illustrating the core description done of the sampling points. The best and most complete descriptions are for wells UE J-13 and UE-25a\#1 for which a publication exists describing each portion of the core from which sample is collected (Heiken and Bevier 1979; Sykes et al. 1979). The complete list of thin section petrography and microprobe analysis for these same samples is listed in Heiken and Bevier (1979) and Sykes et al. (1979).

It was noted that, for well USW H-6, each sample analyzed and reported in the DTN LADB831321 AN98.002 was also described at the USGS Core Warehouse by Levy in Scientific Notebook TWS-ESS-1-11/82-3 (Levy 1998).

Each of the boreholes UE-25a\#1, USW G-2, USW G-3, USW GU-3, and USW G-4 are almost complete in the number of samples that are described in Scientific Notebooks. The descriptions were done at the USGS Core Warehouse for each zone to be sampled. The sampling was then done by the same LANL investigators, and each sample was placed in a plastic bag and labeled (TWS-G6-1/79-24; Bassett 2001d). The plastic bags were filled as the samples were collected along the core, so that opportunity for placing an incorrect sample in the sample bag or mislabeling was avoided.

USGS personnel were not available in the USGS Core Warehouse, so LANL investigators were required to conduct the sample descriptions, collection, and packaging entirely on their own. These same LANL investigators had vested interest in conducting all sampling activities correctly, because they would also be making thin sections, interpreting the lithology of the core, and measuring properties such as elemental content and mineral abundance for their projects and publications.

It is known from conversations with personnel involved in the sampling (Bassett 2001d) that the samples were not always collected in one trip, but in some instances, were collected during the drilling of the borehole, as well as after well completion. It is certain that these missing sample 
descriptions were actually written, in accordance with statements by personnel present, but were described in some Scientific Notebook that is no longer available. In most cases, we have the confirmation of sample collection from the records in the USGS Core Warehouse, discussed above, or notations of receipt of samples at LANL, discussed below.

Owing to the detailed logging of sample depths at the USGS Core Warehouse, and then the use of the same sample numbers in the lab for thin section and microprobe analysis, which served as a checklist for each sample, there was a clear method to determine if any samples were lost or mislabeled. Further, the field description was detailed enough to prevent the switching or confusing of samples because they were then reexamined in the lab for the detailed lithologic and petrographic descriptions published in the reports. There are no reported incidents in which the field descriptions and lab descriptions indicated the need for resampling due to a mix-up, either in the published literature, Scientific Notebooks, or in personal conversations with the investigators (Bassett 2001d)

\subsubsection{Sample Receipt, Crushing, and Forwarding to the XRD Lab}

After describing the hand specimens and collecting the samples at the USGS Core Warehouse, each investigator left the plastic bags of samples at the USGS Core Warehouse for shipping. Upon arrival of the shipped samples at LANL, each investigator was responsible for picking up the sample shipments from the Shipping and Receiving Department at LANL. Samples were taken to the Earth and Environmental Science building at Area 33 where they were stored in bunkers until they were to be analyzed.

At some point, the samples were retrieved from the LANL sample storage area, and taken to the sample preparation lab for crushing and powdering in a shatter-box. A procedure, TWS-ESS-DP-19, Sample Preparation: Rock Powders was written for this part of the sample preparation under the supervision of the investigators (Bassett 2001d). Notations of sample transfer were not required and consequently are infrequently included in Scientific Notebooks; however, where these activities are entered in the Scientific Notebooks located during this qualification process, the information is given in Tables 6 a through $6 \mathrm{e}$. Column 6 of Tables $6 \mathrm{a}-\mathrm{e}$ lists the references to Scientific Notebooks that identify each specific sample as having been received at LANL from the USGS Core Warehouse. Column 7 of Tables 6a through 6e itemizes the references to Scientific Notebooks that identify specific samples as having been sent to either the XRD lab or the thin section lab for analysis.

There was no specific procedure regarding the handling of the samples within LANL; however, there are a significant number of entries in Scientific Notebooks regarding such. These entries are not in accordance with a procedure, rather, they are simply the notations of a specific investigator as he took the initiative to make such entries. Table 7, and columns 6 and 7 of Tables 6a through 6e itemize references of Scientific Notebook documentation for sample receipt, transfers to the thin section lab (abbreviated in the Scientific Notebooks as "TS"), or the X-ray lab. 
Table 7. Notations of Sample Receipts and Transfers in Scientific Notebooks

\begin{tabular}{|c|l|l|}
\hline Well Number & \multicolumn{1}{|c|}{ Notebook(s) } & \multicolumn{1}{c|}{ Notation/Action } \\
\hline UE-25b\#1 & TWS-G-9-6/81-9 & $\begin{array}{l}\text { Core samples received from the USGS are listed, which } \\
\text { includes all samples described in the DTN. }\end{array}$ \\
\hline USW G-1 & TWS G-9-7/80-7 & Core samples received, list is incomplete. \\
\hline USW G-2 & $\begin{array}{l}\text { TWS-G-9-7/80-7 } \\
\text { TWS-G-9-6/81-9 }\end{array}$ & Not complete. \\
\hline USW G-3 & TWS-G-9-6/81-9 & Core samples received, list is incomplete. \\
\hline USW GU-3 & TWS-G-9-6/81-9 & $\begin{array}{l}\text { Core samples received from the USGS are listed, which } \\
\text { includes all samples described in the DTN. }\end{array}$ \\
\hline USW G-4 & $\begin{array}{l}\text { TWS-ESS-1-4/87-33 } \\
\text { TWS-G-9-6/81-9 } \\
\text { TWS-ESS-1-10/82-25 }\end{array}$ & \begin{tabular}{l} 
List is complete. \\
\hline USW H-6
\end{tabular} \\
$\begin{array}{l}\text { TWS-ESS-1-4/87-33 } \\
\text { TWS-G-9-6/81-9 }\end{array}$ & $\begin{array}{l}\text { Core samples received from the USGS are listed, which } \\
\text { includes all samples described in the DTN. }\end{array}$ \\
\hline
\end{tabular}

Crushed and powdered samples were placed in vials and taken to the X-ray lab for analysis. It should be noted that one member of the Data Qualification Team has been to the LANL facility, during this qualification effort, and found that these vials, which contain the remainder of the material from these samples, are still available and can be examined at LANL, Area TA-3, Building SM494, Room 104.

\subsubsection{X-ray Diffraction Analysis}

The X-ray diffraction analysis of each sample actually yielded two results. First, the mineral identification is made. As a sample is analyzed by XRD, the data are initially captured electronically and subsequently a diffractogram of peaks on a strip chart is generated that displays the angles at which the $\mathrm{X}$-ray beam is diffracted by the structure of the crystalline substances in each sample. The peak locations and intensities on this diffractogram are distinctive for each mineral and can be used to determine the identity of the minerals present in the sample. Known mineral patterns tabulated in indexes as in Fink (1976), or Joint Committee on Powder Diffraction Standards (1997), are compared manually or automatically to the patterns detected in the diffractogram to determine the identity of the minerals or combinations of minerals present.

Second, the mineral quantity is determined. Peak intensities and peak-integrated area can be compared to either internal or external standards to quantify the percentage of each mineral in the sample. The quantification process in this DTN was done automatically for the samples reported. The analytical methods are discussed more fully in Section 3.3.

\subsubsection{Potential Error Sources}

The Data Qualification Team has made the following assumptions for the seven core identified in Table 3 as having been previously qualified (CRWMS M\&O 2000a). Qualification is construed to mean that: (1) the cored intervals accurately represent the geology, (2) the core in the USGS Core Warehouse, at the time of sampling, was representative of the core when collected from the borehole, (3) the intervals marked on the core boxes are accurate enough for 
labeling the samples, and 4) no intentional damage or sabotage has rendered the core unreliable. With this stated, the Data Qualification Team then determined that if a problem existed with the sampling it would be: (1) sample "mix-up" or omission rendering the samples mislabeled or misanalyzed, (2) improper descriptions of the interval, and (3) incorrect analysis.

The examination of records of samples collected (described in the field, received, transported, and $\mathrm{X}$-rayed) clearly indicates that the samples were repeatedly matched by sample number (sample depth) and with respect to boreholes. Because the investigators also described the samples in the field, the investigators would have known if a sample did not make it to the laboratory for analysis. Further, because the same group of investigators were all involved in sampling, describing, analysis, and report writing, the opportunity for sample loss or misplacement was avoided. These investigators had a vested interest and a personal knowledge of what to expect and would have detected a missing or mislabeled sample.

Sample handling was minimal; samples were collected one at a time and bagged. The bags were not opened until sample preparation. At that time, individual samples were processed stepwise by crushing, grinding, and then placing in a vial. Finally, the vials were opened and samples were X-rayed, individually, using one instrument. Again, work was done methodically, sequentially, and by the same investigators and technicians.

Regarding sample descriptions, the field descriptions made by the investigators who collected the samples at the USGS Core Warehouse, were for correlation purposes only, not for the formal lithostratigraphic description. Samples were eventually microprobed for elemental analysis, examined in thin section for petrologic analysis, and X-rayed for mineral analysis, so the final published descriptions are detailed and much more informative than the field hand specimen descriptions.

\section{Summary}

The Data Qualification Team has assessed the existing records and determined that the preponderance of evidence indicates that the samples collected are the samples analyzed. The XRD analyses of core are from specific intervals from eight different boreholes. For each sample, a diffractogram identifying the minerals in the sample is available, as is the mineral quantification, with results providing the percentages of identified minerals in each sample. Mineral identification and quantification analyses sheets reside in the XRD laboratory at LANL. This resulted in the list of samples in DTN LADB831321AN98.002.

This list of samples in the DTN was matched with a list of identical sampled intervals in core boxes from which samples have been removed and documented at the SMF. This matching record, between sample spacers in the core boxes and XRD results, is further supported by a record of sample descriptions made by the investigators and recorded in Scientific Notebooks. Scientific Notebooks also recorded receipt of samples at LANL, and, occasionally, note disbursement of samples to the thin section or XRD laboratory.

It is our assertion that although a chain of custody is not absolutely complete, the samples were collected reliably by personnel with knowledge of the importance and ultimate use of the samples, that records exist of sample removal, shipping and analysis, and in view of all the lists 
and interpretations that were required for the final reports, that if a mix-up or omission had occurred, it would have been easily detected. Consequently, it is unlikely that an error occurred in matching the collected sample with the sample analyzed, and the mineral abundance data representing the samples from the eight cores were reliably sampled.

\subsection{X-RAY DIFFRACTION ANALYSIS}

\subsubsection{XRD Methodology}

Mineral identification and mineral abundance determinations reported in DTN LADB831321AN98.002 were all obtained at LANL using standard X-ray diffraction techniques. All analyses reported in this DTN were performed using a Siemens D-500 X-ray diffractometer at LANL between 1982 and 1986.

The methods for operation of the instrument, production of the X-ray diffractograms, identification and quantification of the results were all accomplished following written procedures. The initial Siemens XRD procedure (TWS-G9-DP-16) was prepared by Martha L. Sykes, and was accepted and approved for use at LANL, June 9, 1980. The first revision of this procedure was written by David L. Bish, and received LANL approval on November 24, 1982 (TWS-ESS-DP-16). It was this revised procedure that was in place during the time frame of the sample analyses reported in DTN LADB831321AN98.002. In 1991, the Siemens XRD procedure used in the early 1980s was revised and approved for use on the YMP as LANL-EES-DP-16. The scope of both the original and revised procedures was to provide a description of the machine operation, method of analysis, and documentation used to obtain $\mathrm{X}$-ray powder diffraction data.

The Data Qualification Team technically evaluated methods recommended in this approved 1991 procedure, then evaluated the 1982 procedure that was in place during the time period of the analysis of samples reported in this DTN, to determine whether the methods would produce essentially the same results. In both procedures, the purpose, scope, reference to sample preparation documents, methods of machine operation, data analysis, and QA intent are essentially identical. This derives to some extent from the fact that the X-ray lab employed the same personnel throughout this time period and the diffraction instrumentation used for mineral analyses remained the same. Therefore, not only are the methods of machine operation the same, they are standard across the industry and are specified by the manufacturer in the manuals that accompany the instrument. Further, all training on the instrument was done by Dr. Bish, the machine custodian and lab manager both in the early 1980s and 1991. The training was identical on the same instrument and no one could use the instrument without his training (Bassett 2001d). Dr. Bish was therefore aware of the instrument operation and use, and wrote both the 1982 and the 1991 procedures to accurately reflect the analytical work done in the X-ray lab under his supervision.

Identification of crystalline phases, as described in the 1982 procedure, was done by comparing the peaks on the diffractogram of an analyzed sample to those listed in standard indexes such as Fink (1976) or the Joint Committee on Powder Diffraction Standards (1997). At the time the analyses were done for the data in DTN LADB831321AN98.002, the minerals found in Yucca 
Mountain core were common knowledge; consequently, mineral search procedures were no longer needed (Bassett 2001d).

Quantification of the mineral abundance was done using standard methods as described in the report by Bish and Chipera (1989, pp. 5 through 10) and is the same method used today under the approved OCRWM/YMP QA procedure. This quantification approach is used to determine mineral abundance percentages for all major phases in a sample. This method employs an internal standard for calibration, except in cases where very limited sample volumes were available, in which case an external standard method was used. For example, 1 of 46 samples from UE-25a\#1 and 1 of 129 samples from USW G-1 were analyzed using the external standard method (Bish and Chipera, 1986). The external method was also used exclusively for some of the earlier analyses; e.g., USW G-2 and UE-25b\#1 (Caporuscio et al, 1982). A description of the method is provided in Bish and Vaniman (1985) and Bish and Chipera (1986). The Data Qualification Team found this to be an acceptable alternative approach, but notes that the external standard method may be somewhat less precise than the internal standard method. This is reflected in the larger uncertainties shown in the data sets that used the external method. The difference in method is not considered to be a major problem since both methods are basically semi-quantitative and individual determinations are subject to significant uncertainty for both methods. Users should consider the uncertainties noted in the data sets when using any of these analyses.

In summary, boreholes UE-25 a\#1, USW G-1, USW G-3, USW GU-3, and USW G-4 were analyzed according to the same methods and analysis techniques that are now part of the approved OCRWM/YMP QA procedures. Boreholes USW G-2 and UE25b\#1 and certain samples from the other boreholes were analyzed by an alternate method that the Data Qualification Team found acceptable. The analyses from all of these boreholes will be qualified in this DQR. The summary of qualification issues for core material used in DTN LADB831321AN98.002 is given in Table 8.

Table 8. Summary of Qualification Issues for Core Samples in DTN LADB831321AN98.002

\begin{tabular}{|c|l|}
\hline Well Number & \multicolumn{1}{c|}{ Qualification Issue } \\
\hline UE J-13 & $\begin{array}{l}\text { The core were not reviewed because the results were not } \\
\text { used in the AMRs listed in Section 1.1; therefore, the } \\
\text { samples and analyses remain UQ. }\end{array}$ \\
\hline UE-25a\#1 & Qualified in this DQR. \\
\hline UE-25b\#1 & Qualified in this DQR. \\
\hline USW G-1 & Qualified in this DQR. \\
\hline USW G-2 & Qualified in this DQR. \\
\hline USW G-3 & Qualified in this DQR. \\
\hline USW GU-3 & Qualified in this DQR. \\
\hline USW G-4 & Qualified in this DQR. \\
\hline USW H-6 & Qualified in this DQR. \\
\hline
\end{tabular}

One member of the Data Qualification Team visited the LANL XRD lab and examined the actual diffractograms for the samples reported in this DTN. Table 9 summarizes the examination of the diffractograms. All XRD patterns are in binders and are stored on shelves at LANL in 
Area TA-3, Building SM494, Room 104. The actual diffractogram is stapled to the output files from the mineral quantification program as described in procedure TWS-EES-DP-16.

Table 9. Results of Laboratory Review of X-ray Diffractograms at LANL

\begin{tabular}{|c|l|}
\hline Well Number & \multicolumn{1}{|c|}{ Date Analyzed } \\
\hline UE J-13 & December 1985/March 1986 \\
\hline UE-25a\#1H & February 1983/March 1983 \\
\hline UE-25b\#1 & 1983 \\
\hline USW G-1 & January - February, 1986 \\
\hline USW G-2 & 1983 \\
\hline USW G-3 & June - August, 1982 \\
\hline USW GU-3 & June - August, 1982 \\
\hline USW G-4 & January - May, 1984 \\
\hline USW H6 & February - March, 1983 \\
\hline
\end{tabular}

NOTE: Data from all wells were spot checked correct. This means the diffractograms for the samples listed in DTN LADB831321AN98.002 were physically examined for dates and a cross check between the mineral abundance quantification listed on the diffractogram was performed for each well by comparing the first, last, and several randomly selected patterns in the middle of the sample list for each well. In all cases, the mineral identification and mineral abundance values checked were correct.

The Data Qualification Team determined that the methods used to perform the XRD analysis and determine mineral abundance in core material, as specified in the 1982 procedure, are identical and would yield the same results as would the methods of the 1991 procedure. There are no differences in substance between the methods described in the procedures.

\subsubsection{Software Program for XRD Synthetic Data}

The data in DTN LADB831321AN98.002 also resulted from the use of the software program POWD10 (Pennsylvania State University 1983) in the analysis of two minerals: tridymite and stellerite. Mineral identification by X-ray diffraction requires that the diffraction peak locations ("2 theta" or " $d$ " values) and peak intensities be known for the minerals expected in a sample. The 2 theta or $\mathrm{d}$ values and peak intensities from an accepted standard mineral are then compared to the data obtained from the analyzed sample to determine the identity of crystalline phases. The standard mineral data are derived principally from minerals previously analyzed, reviewed, and accepted by the international community and compiled in indexes such as Fink (1976) and Joint Committee on Powder Diffraction Standards (1997). Standard and accepted XRD data for some known minerals are not yet available and are therefore not in these databases. In the absence of standard reference data for a pure mineral for the comparison, it is common to generate synthetic XRD data using fundamental parameters such as the chemical composition, scattering factors, and crystal structure information. POWD10 (Pennsylvania State University 1983 ) is a widely employed computer program that computes this information, which was written at Pennsylvania State University, and distributed by the author Deane K. Smith (Smith et al. 1983). 
POWD10 (Pennsylvania State University 1983) was used by LANL investigators in the early 1980s to generate synthetic diffraction data for two minerals, stellerite and tridymite. These synthetic data were used to identify these minerals in YMP core samples. The use of POWD10 (Pennsylvania State University 1983) in these studies was well known and documented frequently, e.g., Bish and Chipera (1989). POWD10 (Pennsylvania State University 1983) was an acquired program, but never qualified for OCRWM QA work. As a related effort to this data qualification activity, POWD10 (Pennsylvania State University 1983) was qualified from baseline to retirement and added to the Baseline of Qualified Software. The POWD 10 software program qualification was documented in Bassett $(2001 \mathrm{a}, \mathrm{b}, \mathrm{c})$. The Date Qualification Team has concluded that this software package is now adequately documented.

The Data Qualification Team has concluded that the mineral analyses performed relying on the POWD10 (Pennsylvania State University 1983) output are adequate for generalized use and can be appropriately used in a wide variety of applications, so long as consideration is given to accuracy, precision, and representativeness of the data for an intended use in a technical product.

\section{EVALUATION CONCLUSIONS}

The conclusions of the Data Qualification Team's review of data on mineral analysis are presented below in terms of the two evaluation criteria presented in Bassett et al. (2001).

1. Is there sufficient supporting documentation to ensure that sample data acquisition and sample handling procedures were adequate?

The data considered in this report were obtained from samples of core collected and analyzed by LANL investigators in the early 1980s. The Data Qualification Team considers the methods employed by LANL for sample collection, sample shipping, and sample handling during the time period of data acquisition to be adequate and traceable. The early storage and management of core by the USGS in the USGS Core Warehouse actually resulted in LANL investigators paying more focused attention to core sample retrieval and its subsequent handling. Further, because the LANL team of investigators was small in number, the same investigators were frequently involved in sampling, visual logging, petrographic and chemical analysis, and, finally, XRD analysis. This redundancy in exposure by the same investigators, resulted in multiple entries in

Scientific Notebooks and opportunities to ensure that the correct samples were ultimately analyzed.

Clearly, sufficient documentation exists regarding sample removal, receipt, handling, and analysis to confirm, that even in the absence of a set of approved OCRWM/YMP QA procedures, there is sufficient evidence to assert that the sample handling was accurate, adequate, and defensible, and the resulting mineral analysis data are representative of the correct samples.

Consequently, the data collection methods, documentation, and results are reasonable and appropriate in view of standard practice at the time the data were collected. The Data Qualification Team considers that the collection procedures, available at the time the unqualified data were taken, to be adequate for generalized use. 
2. Are the $\mathrm{XRD}$ analytical methods reasonable and defensible in view of standard measurement and instrumentation practice at the time the data were collected, prior to the approved OCRWM/YMP QA procedures, and are they technically similar to the existing methods?

The Data Qualification Team concludes that the methods used to obtain mineral identity and mineral abundance by XRD analysis, under the 1982 procedure, are essentially identical to the methods in the OCRWM/YMP QA procedure approved in 1991. The instrument, lab management, training, and sample preparation are the same over the time periods considered. Both the 1982 and 1991 procedures are explicit regarding instrument operation and data analysis, and any differences are incidental. In addition, the methods used are the standard methods used throughout the X-ray diffraction community and are described by the instrument manufacturer in the operating manual.

The Data Qualification Team could find no reason to expect the results of the XRD analytical work, accomplished in the 1981 through 1985 time frame in accordance with established LANL procedures, to have been any different if the work were accomplished in accordance with the approved OCRWM/YMP QA procedures accepted in 1991.

\section{RECOMMENDATIONS}

Based on a preponderance of evidence, the mineral abundance analyses of core material reported in DTN LADB831321AN98.002 from the eight cores are recommended for qualification for generalized use in accordance with the criteria defined in Section 2.2 of this DQR. Because these data are subsets of larger data sets presented in this unqualified source DTN, they have been copied and separately identified and assigned new DTNs. The Data Qualification Team recommends the new DTNs identified in Table 10 be qualified where so indicated for generalized use in technical products in support of the Site Recommendation and License Application.

The DTNs LA9908JC831321.001 and LA9910DB831321.001 are classified as TPO and TBV, respectively, the former because it represents model output from CRWMS M\&O (2000b) and the latter is summary XRD data, some of which are unqualified. Both of these DTNs contain DTN LADB831321AN98.002 as a source.

The mineral abundance data from DTN LADB831321AN98.002 contained cuttings and core, only some of which could be qualified here. The mineral abundance data from core are recommended for qualification in this DQR and placed in DTNs MO0101XRDMINAB.001, MO0101XRDDRILC.002, and MO0106XRDDRILC.003. The mineral abundance data from core that were not reviewed by this report remain unqualified (UE J-13) and were placed in a new unqualified DTN, MO0101XRDDRILC.000. The mineral abundance data from cuttings also remain unqualified and were placed in the new unqualified DTN MO0101XRDDRILC.001. Consequently, although some of the mineral abundance data originally in DTN LADB831321AN98.002 have now been qualified, the model output from CRWMS M\&O (2000b) still reflects the use of both cuttings data and core data. CRWMS M\&O (2000b) may need to be revised to indicate that the unqualified data that remains were not used in a direct manner to produce the model. The new qualified DTNs containing mineral abundance data for 
UE-25a\#1, UE-25b\#1, USW G-1, USW G-2, USW G-3, USW GU-3, USW G-4, and USW H-6 are recommended for qualification for general use.

DTNs such as LADV831321AQ97.001, which were impacted by the use of the unqualified software package POWD10 (Pennsylvania State University 1983), have had this restriction remedied by the qualification of POWD10 (Pennsylvania State University 1983). The new DTNs are identified below.

Table 10. List of DTNs Created or Affected by this Data Qualification Report

\begin{tabular}{|c|c|c|}
\hline Original DTN & Comment & New DTN \\
\hline LADV831321AQ97.001 & $\begin{array}{l}\text { The software POWD10 (PSU 1983) used in } \\
\text { the creation of the data has been qualified, } \\
\text { therefore, the data in this DTN are qualified } \\
\text { for general use. }\end{array}$ & No change in DTN number (Q) \\
\hline LADB831321AN98.002 & $\begin{array}{l}\text { The mineral abundance data in source DTN } \\
\text { LADB831321AN98.002 from five core, UE- } \\
25 \text { b\#1, USW G-1, USW G-3, USW GU-3, } \\
\text { USW G-4, have been qualified by this DQR } \\
\text { and placed in a new DTN. }\end{array}$ & MO0101XRDMINAB.001 (Q) \\
\hline LADB831321AN98.002 & $\begin{array}{l}\text { The mineral abundance data in source DTN } \\
\text { LADB831321AN98.002 from one pre-QARD } \\
\text { and still unqualified core, UE J-13, were not } \\
\text { qualified by this DQR and has been placed in } \\
\text { a new unqualified DTN. When the core is } \\
\text { qualified, then the mineral abundance data } \\
\text { can be qualified. }\end{array}$ & MO0101XRDDRILC.000 (UQ) \\
\hline LADB831321AN98.002 & $\begin{array}{l}\text { The previously unqualified core and XRD } \\
\text { analysis methods for USW H-6 have been } \\
\text { found to be acceptable in this report and the } \\
\text { mineral abundance data in source DTN. } \\
\text { LADB831321AN98.002 have been placed in } \\
\text { a new DTN and qualified by this DQR. }\end{array}$ & M00106XRDDRILC.003 (Q) \\
\hline LADB831321AN98.002 & $\begin{array}{l}\text { The mineral abundance data in source DTN } \\
\text { LADB831321AN98.002 from two qualified } \\
\text { core (UE } 25 \text { a\#1 and USW G-2) determined } \\
\text { using alternate XRD methods at LANL were } \\
\text { qualified by this DQR and have been placed } \\
\text { in a new qualified DTN. }\end{array}$ & M00101XRDDRILC.002 (Q) \\
\hline LADB831321AN98.002 & $\begin{array}{l}\text { The mineral abundance data in source DTN } \\
\text { LADB831321AN98.002 from cuttings that } \\
\text { were not qualified by this DQR have been } \\
\text { placed in a new unqualified DTN. }\end{array}$ & MO0101XRDDRILC.001 (UQ) \\
\hline LA9910DB831321.001 & $\begin{array}{l}\text { The data in source DTN } \\
\text { LADB831321AN98.002 qualified by this } \\
\text { DQR have been placed in new DTNs, this } \\
\text { DTN remains UQITBVI }\end{array}$ & No Change in DTN number \\
\hline LA9908JC831321.001 & $\begin{array}{l}\text { The data in source DTN } \\
\text { LADB831321AN98.002 qualified by this } \\
\text { DQR have been placed in new, qualified } \\
\text { DTNs. This DTN remains the same because } \\
\text { it is to be TPO. }\end{array}$ & No Change in DTN number \\
\hline
\end{tabular}




\section{REFERENCES}

\subsection{DOCUMENTS CITED}

Ayres, R.A. and Bonisolli, R.W. 2001. Core Description and Shipping Documentation for Borehole USW-G1. (Copies of documents obtained from files in the YMP Sample Management Facility). Las Vegas, Nevada: BSC. ACC: MOL.20010329.0821.

Bassett, R.L. 2001a. Software Requirements Document (RD) for POWD VI0. DI: 10429-RD-10-00 REV 00. Las Vegas, Nevada: CRWMS M\&O. ACC: MOL.20010320.0083.

Bassett, R.L. 2001b. Software Validation Test Plan (VTP) for POWD V10. DI: 10429-VTP-10-00 REV 00. Las Vegas, Nevada: CRWMS M\&O. ACC: MOL.20010320.0084.

Bassett, R.L. 2001c. Software Validation Test Report (VTR) for POWD V10. DI: 10429-VTR-10-00 REV 00. Las Vegas, Nevada: CRWMS M\&O.

ACC: MOL.20010320.0086.

Bassett, R.L. 2001d. Memo to the Record of Verbal and Written Communications with David Bish at LANL Regarding Software and XRD Mineral Analyses. ACC: MOL.20010214.0016.

Bassett, R.L., Sanchez, P., Jenkins, D.M., and Wemheuer, R. 2001. Data Qualification Plan for $X$-Ray Diffraction Mineral Abundance Data for Use on the Yucca Mountain Project. DQP-NBS-HS-000003 Rev. 00. Las Vegas, Nevada: CRWMS BSC.

ACC: MOL.20010212.0294.

Bish, D.L. and Chipera, S.J. 1986. Mineralogy of Drill Holes J-13, UE-25A\#1, and USW G-1 at Yucca Mountain, Nevada. LA-10764-MS. Los Alamos, New Mexico: Los Alamos National Laboratory. ACC: MOL.19950412.0044.

Bish, D.L. and Chipera, S.J. 1989. Revised Mineralogic Summary of Yucca Mountain, Nevada. LA-1 1497-MS. Los Alamos, New Mexico: Los Alamos National Laboratory.

ACC: NNA.19891019.0029.

Bish, D.L. and Vaniman, D.T. 1985. Mineralogic Summary of Yucca Mountain, Nevada. LA-10543-MS. Los Alamos, New Mexico: Los Alamos National Laboratory.

ACC: MOL.19950412.0041.

Bish, D.L., Carey, J.W., Carlos, B.A., Chipera, S.J., Guthrie, G.D., Jr., Levy, S.S., Vaniman, D.T., and WoldeGabriel, G. 1996. Summary and Synthesis Report of Mineralogy and Petrology Studies for the Yucca Mountain Site Characterization Project. Los Alamos National Laboratory. ACC: MOL.19961230.0026.

Bish, D.L.; Caporuscio, F.A.; Copp, J.F.; Crowe, J.F.; Purson, J.D.; Smyth, J.R.; and Warren, R.G. 1981. Preliminary Stratigraphic and Petrologic Characterization of Core Samples 
from USW-G1, Yucca Mountain, Nevada. LA-8840-MS. Los Alamos, New Mexico:

Los Alamos National Laboratory. ACC: HQS.19880517.1074.

Blaylock, J. 1988. Waste Management Project Office (WMPO) Quality Assurance (QA) Surveillance Report SR-88-007 of the U.S. Geological Society (USGS) Readiness Review Activities (WMPO Action Item \#88-1664). Letter from J. Blaylock (DOE) to L.R. Hayes, May 2, 1988. ACC: HQX.19880516.0088.

Byers, F.M. 2001. Excerpts from Scientific Notebook TWS-EES-1-10/82-25. Los Alamos, New Mexico: Los Alamos National Laboratory. ACC: MOL.20010226.0232.

Caporuscio, F. 1981a. Memorandum titled, "Hand Sample Descriptions of Core Retrieved from USW-G2." Memorandum from F. Caporuscio to Distribution. September 4, 1981.

ACC: NNA.19900418.0163.

Caporuscio, F. 1981b. Memorandum titled, "USW-G2 Core Samples." Memorandum from F. Caporuscio to Distribution. December 4, 1981. ACC: NNA.19900418.0164.

Caporuscio, F.A. 2001a. Excerpts from Scientific Notebook, TWS-G9-6/81-9. Los Alamos, New Mexico: Los Alamos National Laboratory. ACC: MOL.20010226.0233.

Caporuscio, F.A. 2001b. Excerpts from Scientific Notebook TWS-G9-7/80-7. Los Alamos, New Mexico: Los Alamos National Laboratory. ACC: MOL.20010226.0231.

Caporuscio, F.; Vaniman, D.; Bish, D.; Broxton, D.; Arney, B.; Heiken, G.; Byers, F.; Gooley, R.; and Semarge, E. 1982. Petrologic Studies of Drill Cores USW-G2 and UE25b-1H, Yucca Mountain, Nevada. LA-9255-MS. Las Alamos, New Mexico: Los Alamos National Laboratory. ACC: HQS.19880517.1110.

Carroll, P.I.; Caporuscio, F.A.; and Bish, D.L. 1981. Further Description of the Petrology of the Topopah Spring Member of the Paintbrush Tuff in Drill Holes UE25A-1 and USW-G1 and of the Lithic-Rich Tuff in USW-G1, Yucca Mountain, Nevada. LA-9000-MS. Los Alamos, New Mexico: Los Alamos National Laboratory. ACC: NNA.19870406.0423.

Chipera, S.J. 1985. Notebook Number S-9075 for Steve J. Chipera. Scientific Notebook TWS-ESS-1-9/85-10. Los Alamos, New Mexico: Los Alamos National Laboratory.ACC: NNA.19900605.0236.

Chipera, S.J.; Vaniman, D.T.; Carlos, B.A.; and Bish, D.L. 1995. Mineralogic Variation in Drill Core UE-25 UZ\#16, Yucca Mountain, Nevada. LA-12810-MS. Los Alamos, New Mexico: Los Alamos National Laboratory. ACC: NNA.19940427.0099.

CRWMS M\&O 2000a. Data Qualification Report: Drill Core, Core Samples, Core Photos, and Geophysical Logs for Boreholes, UE-25 a\#1, UE-25 a\#5, UE-25 a\#6, UE-25 a\#7, UE-25 b\#1, USG G-1, USG G-2, USG G-3, USG G-4, USW GU-3. TDR-NBS-GS-000006 Rev. 0. Las Vegas, Nevada: CRWMS M\&O. ACC: MOL.20000420.0396. 
CRWMS M\&O 2000b. Mineralogical Model (MM3.0) - MDL-NBS-GS-000003, Rev. 00, ICN 01. Las Vegas, Nevada: CRWMS M\&O. ACC: MOL.20000120.0477.

Fenix and Scisson, Inc. 1986a. NNWSI Hole Histories: UE-25a\#1, UE-25a\#3, UE-25a\#4, $U E-25 a \# 5, U E-25 a \# 6, U E-25 a \# 7$. DOE/NV/10322-9. Mercury, Nevada: Fenix and Scission, Inc. ACC: HQS.19980517.1199.

Fenix and Scisson, Inc. 1986b. NNWSI Hole History: UE-25b\#1. DOE/NV/10322-13. Mercury, Nevada: Fenix and Scission, Inc. ACC: HQS.19880517.1200.

Fenix and Scisson, Inc. 1987a. NNWSI Hole Histories: USW G-1, USW G-2, USW G-3, USW G-4, USW GA-1, USW GU-3. DOE/NV/10322-9. Mercury, Nevada: Fenix and Scission, Inc. ACC: HQS.19880517.1194.

Fenix and Scisson, Inc. 1987b. NNWSI Hole Histories: USW H-1, USW H-3, USW H-4, USW $H-5$, USW H-6. DOE/NV/10322-9. Mercury, Nevada: Fenix and Scission, Inc.

ACC: NNA.19871006.0069.

Fink 1976. Powder Diffraction File, Search Manual, Fink Method, Inorganic. Publication SMF-26, Joint Committee on Powder Diffraction Standards. Swarthmore, Pennsylvania. Readily available.

Finnegan, K. P. 2001. Core Box Spreadsheets in EXCEL for Boreholes: UE-25 b\#1, UE-25 c\#1, $U E-25$ c\#2, UE-25 c\#3, USW G-1, USW G-2, USW G-3, USW G-4, USW GU-3. SM\&DD. Core Box Spreadsheets Optical Disk. Las Vegas, Nevada: BSC. ACC: MOL.20010214.0033.

Gertz, C.P. 1988. "Use of Existing Geologic Samples and Related Data." Letter from C.P. Gertz (DOE) to L.D. Ramspott (LLNL), L.R. Hayes (USGS), D.T. Oakley (LANL), T.O. Hunter (SNL), M.E. Spaeth (SAIC), J.C. Calovini (H\&N), R.F. Pritchett (REECo), and R.L. Bullock (F\&S), January 12, 1988. ACC: HQX.19880119.0016.

Heiken, Grant.; and Bevier, Mary Lou. 1979. Petrology ofTuff Units from the J-13 Drill Site, Jackass Flats, Nevada. LA-7563-MS. Los Alamos, New Mexico: Los Alamos National Laboratory. ACC: HQS.19880517.1987.

Horton, G. Donald 1990. "U.S. Department of Energy (DOE) Office of Civilian Radioactive Waste Management (OCRWM) Acceptance of the Los Alamos National Laboratories (Los Alamos) Quality Assurance (QA) Program." Letter from G. D. Horton (Director, Office of Quality Assurance) to D.E. Shelor (Acting Associate Director, Systems and Compliance, DOE) December 21, 1990, with enclosures, "SDR Severity Level Checklist" and "Surveillances of the Los Alamos QA Program Performed after April 2, 1990.” ACC: HQO.19910107.0034.

Joint Committee on Powder Diffraction Standards 1997. International Centre for Diffraction Data. PCPDFWIN. v. 1.30. Readily available.

Levy, S. S. 1998. Alteration History - Field Sampling Notebook Pi: Schon S Levy, Scientific Notebook LANL TWS-ESS-1-11/82-3. Los Alamos, New Mexico: Los Alamos National Laboratory. ACC: MOL.19980527.0146. 
Semarge, R.E. 1983. Clay and Mineral Laboratory Research Notebook. Scientific Notebook TWS-ESS-1-4/87-33. Los Alamos, New Mexico: Los Alamos National Laboratory.

ACC: NNA.19900605.0237.

Smith, Deane K.; Nichols, Monte C.; and Zolensky, Michael E. 1983. User Manual for POWD 10 - A Fortran IV Program for Calculating X-ray Diffraction Patterns - Version 10. Department of Geosciences, The Pennsylvania State University. ACC: MOL.20010320.0085.

Spengler, R.W. 2001. Technical Data Record for Stratigraphic Contacts Boreholes UE-25 A\#5, \#6; USW H-3, -6; UE-25 B\#1; UE-25 P\#1: USW UZ-1, -6; 11 USW UZ-N Boreholes; UE-25 UZN \#63, UE-25 NRG\#1, \#3; USW VH-1; USW WT-7, -11; UE-25 WT\#17.

DTN: GS000608314211.003. ACC: MOL.20010430.0264.

Sykes, M. L. 2001a. Excerpts from Scientific Notebook TWS-G9-3/80-10.

ACC: MOL.20010226.0235.

Sykes, M. L. 2001b. Excerpts from Scientific Notebook TWS-G9-3/80-17.

ACC: MOL.20010226.0230.

Sykes, Martha L.; Heiken, Grant H.; and Smyth, Joseph R. 1979. Mineralogy and Petrology of tuff units from the UE25a-1 drill site, Yucca Mountain, Nevada, LA-8139-MS. Los Alamos, New Mexico: Los Alamos National Laboratory. ACC: NNA.19870406.0186.

Vaniman, David 2001. Excerpts from Scientific Notebook TWS-G6-8/79-50. Los Alamos, New Mexico: Los Alamos National Laboratory. ACC: MOL.20010226.0234.

\subsection{CODES, STANDARDS, REGULATIONS, AND PROCEDURES}

AP-3.15Q, Rev 3, ICN 2. Managing Technical Product Inputs. Washington, D.C.: U.S. Department of Energy, Office of Civilian Radioactive Waste Management. ACC: MOL.20001109.0051.

AP-SI.1Q, Rev 2, ICN 4, ECN 1. Software Management. Washington, D.C.: U.S. Department of Energy, Office of Civilian Radioactive Waste Management. ACC: MOL.20001019.0023.

AP-SIII.2Q, Rev. 0, ICN 4. Qualification of Unqualified Data and the Documentation of Rationale for Accepted Data. Washington, D.C.: U.S. Department of Energy, Office of Civilian Radioactive Waste Management. ACC: MOL.20020627.0299

DOE (U.S. Department of Energy) 2002. Quality Assurance Requirements and Description. DOE/RW-0333P, Rev. 11. Washington, D.C.: U.S. Department of Energy, Office of Civilian Radioactive Waste Management. ACC: MOL.20020506.0915.

LANL-EES-DP-16, Rev. 5, 1991. Siemens X-ray Diffraction Procedure. Los Alamos, New Mexico: Los Alamos National Laboratory. LANL-EES-DP-16, R5.

ACC: NNA.19920430.0206. 
TWS-G9-DP-16, Rev. 0, 1980. Siemens X-ray Diffraction Procedure. Los Alamos, New Mexico: Los Alamos National Laboratory. ACC: NNA.19891030.0116.

TWS-ESS-DP-16, Rev. 1, 1982. Siemens X-ray Diffraction Procedure. Los Alamos, New Mexico: Los Alamos National Laboratory. ACC: NNA.19870501.0135.

TWS-ESS-DP-19, Rev. 1. Sample Preparation: Rock Powders. Los Alamos, New Mexico: Los Alamos National Laboratory. ACC: NNA.19870501.0136.

TWS-G6-1/79-24, Rev. 0, 1979. NTS Core Petrography Procedure. Los Alamos, New Mexico: Los Alamos National Laboratory. ACC: NNA.19891030.0103.

\subsection{SOURCE DATA, LISTED BY DATA TRACKING NUMBER}

GS000608314211.003. Stratigraphic Contacts for 26 Yucca Mountain Boreholes. Submittal date: $4 / 9 / 01$.

LA9908JC831321.001. Mineralogic Model "MM3.0" Version 3.0. Submittal date: 08/16/99.

LA9910DB831321.001. Mineralogic Variation in Drill Holes. Submittal date: 11/18/99.

LADB831321AN98.002. Revised Mineralogic Summary of Yucca Mountain, Nevada.

Submittal date: $05 / 26 / 98$.

LADV83132AQ97.001. Mineralogic Variation in Drill Holes. Submittal date: 05/28/97.

\subsection{OUTPUT DATA, LISTED BY DATA TRACKING NUMBER}

MO0101XRDDRILC.000. XRD analyses of Drill Core from Boreholes UE J-13 and USW H-6. Submittal Date: 01/26/01.

MO0101XRDDRILC.001. XRD Analyses of Drill Core from Boreholes UE-25 J-12, USW WT-1, USW H-3, USW H-4, USW WT-2, UE-25 p\#1 and USW H-5. Submittal date: 01/26/01.

MO0101XRDDRILC.002. XRD Analyses of Drill Core from Boreholes UE-25a\#1 and USW G-2. Submittal Date: $01 / 26 / 01$.

MO0106XRDDRILC.003. XRD Analyses of Drill Core from Borehole USW H-6. Submittal Date: $06 / 08 / 01$.

MO0101XRDMINAB.001. XRD Analyses of Drill Core from Boreholes UE-25 b\#1, USW G-1, USW G-3, USW GU-3 and USW G-4. Submittal Date: 01/26/01.

\subsection{SOFTWARE}

Pennsylvania State University 1983. Software Code: A Fortran IV Program for Calculating X-ray Diffraction Patterns, Version 10. DI: LV-2000-292. University Park, Pennsylvania. ACC: MOL.20010320.0087. 


\section{INTENTIONALLY LEFT BLANK}

